NBER WORKING PAPER SERIES

\title{
HOW RESILIENT IS MORTGAGE CREDIT SUPPLY? EVIDENCE FROM THE COVID-19 PANDEMIC
}

\author{
Andreas Fuster \\ Aurel Hizmo \\ Lauren Lambie-Hanson \\ James Vickery \\ Paul S. Willen \\ Working Paper 28843 \\ http://www.nber.org/papers/w28843
}

\author{
NATIONAL BUREAU OF ECONOMIC RESEARCH \\ 1050 Massachusetts Avenue \\ Cambridge, MA 02138 \\ May 2021
}

We thank Eric Hardy, Natalie Newton and Dick Oosthuizen for outstanding research assistance, Scott Frame, Philipp Schnabl, Felipe Severino, and numerous other colleagues for comments, as well as workshop participants at the Journal of Finance and Fama-Miller Center Conference on the Financial Consequences of COVID-19, University of Zurich, Louisiana State University, the Philadelphia Fed, Penn State University, Dartmouth (Tuck), the Dallas Fed, and the CFPB Research Conference. Opinions expressed in this paper are those of the authors and do not represent the opinions of the Federal Reserve Banks of Boston or Philadelphia, the Federal Reserve Board, the Federal Reserve System, the Swiss National Bank, or the National Bureau of Economic Research.

NBER working papers are circulated for discussion and comment purposes. They have not been peer-reviewed or been subject to the review by the NBER Board of Directors that accompanies official NBER publications.

(C) 2021 by Andreas Fuster, Aurel Hizmo, Lauren Lambie-Hanson, James Vickery, and Paul S. Willen. All rights reserved. Short sections of text, not to exceed two paragraphs, may be quoted without explicit permission provided that full credit, including $(\odot$ notice, is given to the source. 
How Resilient Is Mortgage Credit Supply? Evidence from the COVID-19 Pandemic Andreas Fuster, Aurel Hizmo, Lauren Lambie-Hanson, James Vickery, and Paul S. Willen NBER Working Paper No. 28843

May 2021

JEL No. G21,G23,G28

\begin{abstract}
$\underline{\text { ABSTRACT }}$
We study the evolution of US mortgage credit supply during the COVID-19 pandemic. Although the mortgage market experienced a historic boom in 2020, we show there was also a large and sustained increase in intermediation markups that limited the pass-through of low rates to borrowers. Markups typically rise during periods of peak demand, but this historical relationship explains only part of the large increase during the pandemic. We present evidence that pandemicrelated labor market frictions and operational bottlenecks contributed to unusually inelastic credit supply, and that technology-based lenders, likely less constrained by these frictions, gained market share. Rising forbearance and default risk did not significantly affect rates on "plain vanilla" conforming mortgages, but it did lead to higher spreads on mortgages without government guarantees and loans to the riskiest borrowers. Mortgage-backed securities purchases by the Federal Reserve also supported the flow of credit in the conforming segment.
\end{abstract}

Andreas Fuster

Swiss National Bank

Boersenstrasse 15

CH-8022 Zurich

Switzerland

and CEPR

andreas.fuster@gmail.com

Aurel Hizmo

Federal Reserve Board

20th and C St NW

Washington, DC 20551

aurel.hizmo@frb.gov

Lauren Lambie-Hanson

Federal Reserve Bank of Philadelphia

10 Independence Mall

Philadelphia, PA 19106

lslambiehanson@alum.mit.edu
James Vickery

Federal Reserve Bank of Philadelphia

james.vickery@phil.frb.org

Paul S. Willen

Federal Reserve Bank of Boston

Research Department

600 Atlantic Avenue

Boston, MA 02210-2204

and NBER

paul.willen@bos.frb.org 


\section{Introduction}

2020 was an extraordinary year for the US mortgage market. Lenders underwrote a record $\$ 4$ trillion in new mortgages, a far higher volume than in any year since 2003. ${ }^{1}$ On the price side, the Freddie Mac Primary Mortgage Market Survey (PMMS) rate on 30-year fixed-rate mortgages (FRMs) fell below 3 percent for the first time since the series began in 1970, reaching lows of about 2.7 percent. Rocket Companies, the largest US mortgage lender, recorded \$9.4 billion in net income, up more than 900 percent from 2019.

Market participants in March of 2020 would not have expected such good news. The emergence of COVID-19 appeared to presage bad times for the industry. With the spread of the virus, lockdowns, and social distancing, how would lenders close loans? Who would buy houses? How would mortgage servicers deal with commitments to pay principal and interest to investors as well as taxes and insurance when Congress had told borrowers that they could postpone payment without penalty? Yet borrowers and lenders seemingly overcame all these challenges.

Underlying these positive outcomes, however, are signs that the mortgage market has not functioned entirely normally during the pandemic. In addition to historically high lending and historically low rates, we have seen historically high spreads between mortgage rates and commonly used benchmarks. Figure 1 shows that while mortgage and Treasury rates generally co-move closely, the difference between the 30-year FRM rate and 10-year Treasury yield widened significantly during the pandemic, peaking at levels not seen since the 2008 financial crisis. ${ }^{2}$ And while mortgage lenders were highly profitable, industry practitioners reported tighter credit standards in response to the heightened risk of forbearance and delinquency. ${ }^{3}$

In this paper, we study the evolution of the mortgage market during the COVID-19 pandemic and evaluate the extent to which the events of the pandemic led to a contraction

\footnotetext{
${ }^{1}$ From 2008 through 2019, annual mortgage originations never exceeded \$2.4 trillion, and they exceeded \$2 trillion only three times. Lending volume was \$3.7 trillion in 2003, which was the previous record. The 2003 lending boom remains significantly larger in real terms or scaled by the stock of outstanding mortgages, however. Statistics are from Inside Mortgage Finance and can be seen on p. 8 of Urban Institute (2021).

${ }^{2}$ The effective duration of a 30 -year mortgage is much shorter than 30 years due to prepayment. Although widely used, 10-year Treasury yields are not a perfect benchmark for reasons we explain below.

${ }^{3}$ For example, the Mortgage Bankers Association estimates that mortgage credit availability dropped sharply at the onset of the pandemic to its lowest level in six years, and it had not recovered much through the end of 2020 (Mortgage Bankers Association, 2021).
} 
Figure 1: Mortgage Rates and Treasury Yields

(a) Interest Rates

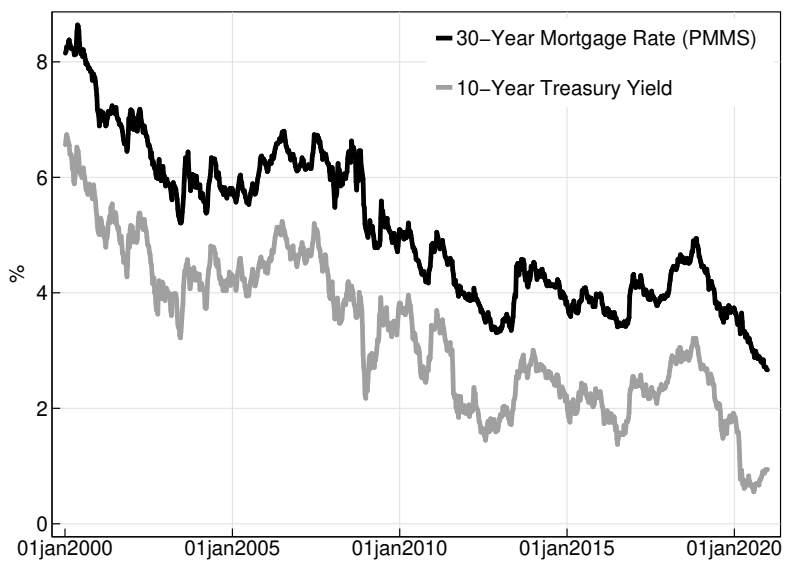

(b) Mortgage-Treasury Spread

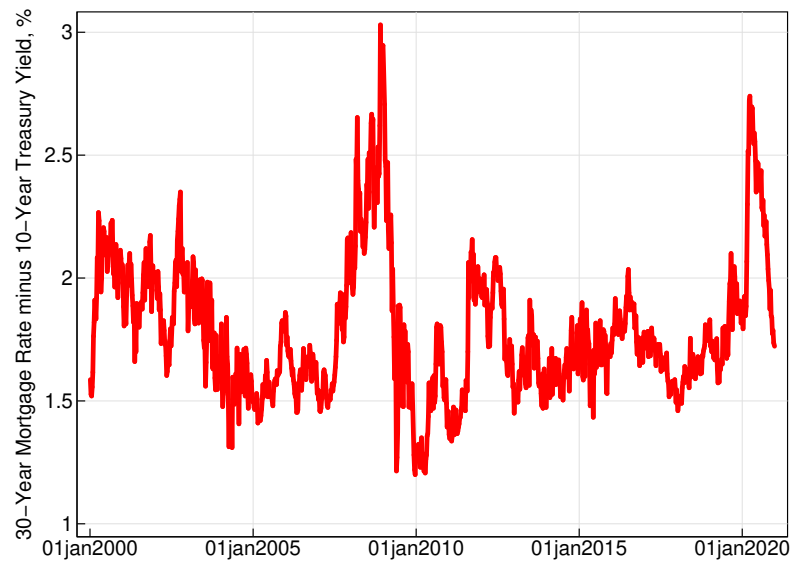

Data source: Freddie Mac 30-Year Fixed Rate Mortgage Average in the United States [MORTGAGE30US] and Board of Governors of the Federal Reserve System (US) 10-Year Treasury Constant Maturity Rate [DGS10], retrieved from FRED, Federal Reserve Bank of St. Louis. Sample period through end of 2020.

in mortgage credit supply. Our analysis combines financial market data on prices and yields for mortgage-backed securities (MBS), time-series data on mortgage interest rates, microdata on mortgage rate offers and interest rate locks from the Optimal Blue platform, and several other mortgage data sets. We make the following four main points.

1. Except for a period of financial market turbulence in March 2020, the high mortgageTreasury spread is more than accounted for by a sustained 100 basis point increase in the "primary-secondary" spread-that is, by an increase in the price of intermediation in the primary mortgage market. A similar spike in the intermediation markup is observed based on measures of gain-on-sale earned by mortgage lenders. Thus, the situation is quite different from 2008, when mortgage rates were elevated due to the high spread on MBS in financial markets.

2. Intermediation markups typically rise during refinancing booms due to capacity constraints (Fuster et al., 2017). But this historical relationship accounts for only part of the increase in markups in 2020. In other words, the elasticity of mortgage supply was abnormally low. We present evidence that operational issues and labor market frictions related to the pandemic contributed to this lower elasticity. Consistent with these frictions, we show that technology-based ("fintech") lenders gained market share among mortgages that are more complex and labor intensive to originate. 
3. The mortgage rate spread widened for loans bearing the greatest credit risk for financial intermediaries. These loans span the socio-economic spectrum, including both non-guaranteed jumbo mortgages to high-income borrowers, and low-creditscore Federal Housing Administration (FHA) mortgages. ${ }^{4}$ The number of lenders offering credit in these segments of the market also fell sharply. While forbearance and default risk was not an important driver of higher markups for a typical prime mortgage, it did lead to a contraction of supply in some other parts of the market.

4. MBS purchases by the Federal Reserve ("quantitative easing" or QE) lowered mortgage rates and supported mortgage credit supply. We identify these effects in part using institutional features of the "to-be-announced" forward market.

We are also able to rule out several plausible alternative explanations for the sharp rise in mortgage markups. Using geographic variation, we show that factors related to local market competition, or the direct macroeconomic and health effects of the virus, do not play an important role; instead, the rise in markups was broadly based. Using the cross section of mortgages, we show that forbearance and default risk did not play a significant role in producing the higher spreads observed in the prime conforming market, where lenders are less exposed to default than in other market segments. Finally, we show that borrowers shopped more and switched more frequently between lenders during the pandemic; along with our evidence on local competition, this speaks against the hypothesis that the high markups reflect an increase in lender pricing power.

Beyond shedding light on the financial effects of the pandemic, our results yield more general lessons about the resilience of the US mortgage finance system and the frictions that limit interest rate pass-through to borrowers. A first lesson is that, despite recent improvements in information technology, industry capacity constraints still bind during periods of peak demand. Although mortgage rates fell to record lows in 2020, our results imply that rates paid by borrowers would be lower still under a system where rates adjust automatically with market yields during an economic downturn, as in the automatic stabilizer mortgage proposed by Eberly and Krishnamurthy (2014) (see also Guren et al., 2020; Campbell et al., 2020), or in a system with a larger role for adjustable-rate mortgages. That said, we also find that fintech lenders gained market share during the pandemic, particularly for complex loans, suggesting that technology indeed helps ameliorate capacity

${ }^{4}$ FHA mortgages are government guaranteed, but these guarantees do not fully insulate mortgage intermediaries against default risk. See Kim et al. (2018) and the discussion in Section VI for more details. 
constraints and overcome operational bottlenecks, consistent with Fuster et al. (2019). ${ }^{5}$

A second lesson is that government guarantees, which play a key role in the agency mortgage market, supported intermediation and lowered rates in the face of a large macroeconomic shock, as was also the case during the Great Recession (Calem et al., 2013; Vickery and Wright, 2013). At the same time, our results highlight the limits of these guarantees. Because lenders are not fully indemnified against risk, especially in the FHA segment, the pandemic did result in a contraction in supply for the riskiest borrowers. We are also able to disentangle the effects of government credit guarantees and Fed QE (e.g., Di Maggio et al., 2020) by comparing conforming, jumbo, and super-conforming loans (the latter carry a government guarantee but are only partly eligible for Fed purchases). We find that both QE and government guarantees supported credit supply in the conforming segment, although guarantees appear to have had a more persistent effect.

The evidence in this paper adds to a large body of research about the transmission of monetary policy and interest rate shocks through the mortgage market and the role of financial frictions, including Berger et al. (2020), Di Maggio et al. (2017), Fuster et al. (2013), and Fuster et al. (2017); see Amromin et al. (2020) for a recent review. Our results are also related to research on the growing presence of nonbank mortgage intermediaries, which now originate more than half of new loans and are more sensitive to liquidity risk (Kim et al., 2018; Jiang et al., 2020; Buchak et al., 2018).

Finally, we contribute to a growing body of research about the mortgage market and consumer credit markets more generally during the COVID-19 pandemic. ${ }^{6}$ An et al. (2021), Cherry et al. (2021), Capponi et al. (2021), and McManus and Yannopoulos (2021) study mortgage forbearance during the pandemic. Agarwal et al. (2021) show that savings from refinancing during the pandemic are more skewed toward higher-income borrowers than in earlier refinancing waves. Work on other consumer credit markets includes Iverson et al. (2020) on bankruptcy and Horvath et al. (2020) on credit card borrowing.

\footnotetext{
${ }^{5}$ Erel and Liebersohn (2020) show that nonbank fintech lenders also gained importance in small-business lending during the pandemic, accounting for a substantial portion of Paycheck Protection Program (PPP) loans. Kwan et al. (2021) show that banks with stronger information technology (IT) capabilities originated more PPP loans and attracted more deposits during the pandemic.

${ }^{6}$ Bracke et al. (2020) conduct a study similar in several respects to ours for the UK mortgage market, finding evidence of tighter credit standards and a drop in lending after the onset of the pandemic. This again suggests that government guarantees (which are absent in the UK) were important in sustaining US lending.
} 


\section{Data}

\section{II.A Optimal Blue}

The Optimal Blue platform connects mortgage lenders to whole loan investors, allowing lenders to search for pricing information, initiate rate locks, and sell mortgages. ${ }^{7}$ Lenders are typically nonbank mortgage companies, but smaller banks and credit unions are also represented. Investors include large banks and other institutions that retain loans purchased on the platform in portfolio or package them for securitization. More than 1,000 lenders and over 200 investors are active on the platform, and Optimal Blue estimates that the platform has been used to lock one-third of US mortgage originations in recent years. Coverage may be even higher for 2020 due to a rise in the share of nonbank lending. ${ }^{8}$

Our analysis uses the following two forms of information produced by the platform.

Rate locks. Rate lock data reflect individual locks for mortgages processed by Optimal Blue, and include a comprehensive set of underwriting variables including the loanto-value (LTV) ratio, FICO score, debt-to-income (DTI) ratio, loan amount, loan program, purpose (purchase or refinance), asset and income documentation, employment, occupancy status, property type, and ZIP code. The data also include lender, branch, and loan officer identifiers. The data cover about 280 metropolitan areas as well as rural areas.

Rate lock data have several advantages over servicing data often used in mortgage research. First, the data include not only the mortgage note rate, but also the discount points or credits paid or received by the borrower and the duration of the lock. This is important because in practice borrowers select from a menu of rate-point combinations, and points vary through time and across loans. Second, we observe the date and time of the rate lock, as opposed to the closing date, which generally differs from the pricingrelevant lock date by weeks or months. ${ }^{9}$ Third, the data are available in near real time.

Mortgage offers. We also use data on the menu of loan contracts and associated inter-

${ }^{7}$ Optimal Blue data (as referenced throughout) are anonymized mortgage market/rates data that do not contain lender or customer identities or complete rate sheets.

${ }^{8}$ Among the top 50 lenders by volume, nonbanks accounted for 69 percent of originations in 2020, and 74 percent in 2020:Q4, up from 60 percent in 2019. Source: Inside Mortgage Finance, Jan. 29, 2021.

${ }^{9}$ The rate is typically locked about the time when the borrower submits a loan application, but it can happen before or after. 
est rates offered by lenders through Optimal Blue's "Pricing Insight" engine. The engine allows users to retrieve the real-time distribution of offers (that is, combinations of rates and net points and fees) for a loan with given characteristics in a particular local market. The interface is designed for lenders to compare their pricing with that of their peers. We use the engine to run daily searches in one local market (Los Angeles), twice-weekly searches in four markets, and weekly searches in 15 additional markets, collecting offer data for 100 loan types representing different combinations of FICO score, LTV ratio, loan program, purpose (purchase or cash-out refinance), occupancy (owner-occupied or investor), rate type (30-year fixed or $5 / 1$ adjustable), and loan amount. ${ }^{10}$

Mortgage offer rates represent a direct measure of supply that can be observed regardless of whether the offer results in a loan in equilibrium. The Insight data also allow us to see how the number of lenders active in different segments of the market evolves over the pandemic. A limitation of the offer data, however, is that there is no fixed lender identifier, meaning we cannot track lenders over time or include lender fixed effects.

\section{II.B Other Data Sources}

We use a variety of other data sources. For mortgage rates, in addition to Optimal Blue, we use data from the Freddie Mac Primary Mortgage Market Survey and the Mortgage Bankers Association (MBA). All MBS pricing information comes from J.P. Morgan Markets. Mortgage servicing rights valuation data are provided by SitusAMC, an independent valuation service company. For direct evidence on lender income and costs, we use the MBA Quarterly Performance Report. Data on mortgage industry employment come from the Bureau of Labor Statistics' (BLS) Current Employment Statistics, and job postings come from Burning Glass Technologies. Data on county-level daily COVID-19 cases come from the New York Times GitHub repository. Evidence on borrower search is obtained from Google Trends. We also use public Home Mortgage Disclosure Act (HMDA) data for geographic market characteristics (e.g., lender concentration). Lastly, we use loanlevel data from eMBS on mortgages securitized through Fannie Mae, Freddie Mac, and Ginnie Mae to study fintech lending, and Black Knight McDash servicing data ("McDash data") to study the jumbo market and to cross-validate several of our results.

\footnotetext{
${ }^{10}$ All searches condition on full income, asset, and employment documentation, and require that the mortgage finances a single-unit home. If a lender represents more than one investor, we observe the most competitive investor offer. For more details see Bhutta et al. (2021), who compare mortgage offer rates and lock rates to study the efficiency of borrower search in the mortgage market.
} 


\section{Rates and Markups for Conforming Mortgages}

In this section, we measure the evolution of mortgage rates and markups in 2020. We start, in Section III.A, by breaking down the spread between mortgage rates and benchmark 10year Treasury yields into several components. In Section III.B, we use this decomposition to show that one component, the primary-secondary spread, a measure of intermediary markups, largely explains the behavior of the mortgage-Treasury spread. In Section III.C, we calculate intermediary markups using gain-on-sale, an alternative and arguably more accurate measure. Gain-on-sale paints a very similar picture: Both methods imply large and persistent increases in markups. In Section III.D, as a reality check, we look directly at intermediary income reported by lenders, which also shows large gains.

Our focus in this section and in Section IV is on the largest segment of the market, conventional conforming loans (which are generally securitized via Fannie Mae or Freddie Mac). These are typically "plain-vanilla" 30-year fixed rate loans to prime borrowers making a down payment of 20 percent or more. As the core of the market, conforming rates and quantities are closely tracked by policymakers and market participants.

\section{III.A Decomposing the Mortgage-Treasury Spread}

Define $r_{p}$ as the "primary mortgage rate" paid by the borrower, $r_{10}$ as the yield on a 10year Treasury note, and $r_{s}$ as the yield on a new-production MBS into which a typical newly originated mortgage with note rate $r_{p}$ would be securitized. We can decompose the mortgage-Treasury spread as

$$
r_{p}-r_{10}=\underbrace{r_{p}-r_{s}}_{\text {Primary-secondary spread }}+\underbrace{r_{s}-r_{10}}_{\text {MBS yield spread }} .
$$

We can furthermore decompose the MBS yield spread as follows:

$$
r_{s}-r_{10} \approx \underbrace{\left(r_{\text {dur }}-r_{10}\right)}_{\text {Duration Adjustment }}+\begin{gathered}
\text { Option } \\
\text { Cost }
\end{gathered}+\begin{gathered}
\text { Option-Adjusted } \\
\text { Spread (OAS) }
\end{gathered} .
$$

Duration Adjustment reflects the fact that the MBS may have a different duration from the 10-year Treasury. MBS duration is not known ex-ante, since it depends on prepayment 
behavior, so instead it is estimated using a model that simulates different interest rate and prepayment paths. Option Cost measures the value of the borrower's prepayment option; the borrower can prepay at any time and will tend to do so especially when rates fall (in order to refinance into a new loan). Since MBS investors are short this option, they require compensation in terms of a higher MBS yield. Finally, Option-Adjusted Spread (OAS) is a residual that captures various factors that affect relative pricing between Treasuries and MBS, such as liquidity differences, the risk-bearing capacity of marginal investors in the two markets, relative bond supply, perceived credit risk differences, and non-interest-rate prepayment risk (Boyarchenko, Fuster, and Lucca, 2019). ${ }^{11}$

\section{III.A.1 Measurement}

While headline mortgage rates and Treasury yields are readily available, decomposing the mortgage-Treasury spread into the four components in equations (1) and (2) is less straightforward. Most important, MBS yields, durations, option costs, and OAS are not directly observed, but are obtained based on MBS pricing models featuring interest rate simulations and prepayment projections; we rely on models from J.P. Morgan Markets, as noted earlier. Two further complications are that (i) MBS are traded in coupons of 50 basis point (bp) increments, and a mortgage with a given note rate could be securitized into different new production coupons; and (ii) MBS investors do not receive the entire note rate, as some portion of the cash flow is diverted to pay for the agency credit guarantee (g-fees) and servicing. We account for these factors by calculating a net note rate:

$$
\text { Net Note Rate }=r_{p}-g-s \text {. }
$$

Our baseline measure of $r_{p}$ is the 30-year FRM rate from the Freddie Mac PMMS; for the guarantee fee $g$ we take the effective g-fee on new production MBS from Fannie Mae's 10$Q$ disclosures; and the (base) servicing fee $s$ is set to $25 \mathrm{bp}$, which is the market convention for MBS issued by the government-sponsored enterprises (GSEs) Fannie Mae and Freddie Mac. We then calculate the MBS yield, duration, option cost, and OAS by interpolating values between the two MBS coupons on either side of the net note rate.

${ }^{11}$ For textbook descriptions of MBS pricing, see Fabozzi (2016) or Davidson and Levin (2014). Note that the decomposition in (2) is not exact, since the OAS and the "zero-volatility spread" (which is the sum of OAS and option cost) are calculated as an average spread relative to each point on the interest rate curve based on which future cash flows are discounted, while the left-hand-side measure is a simple spread at aiven point on that curve. 


\section{III.B What Happened over 2020? How Does It Compare with 2007-09?}

Panel A of Figure 2 traces out the evolution of the mortgage-Treasury spread in 2020 in terms of changes relative to the beginning of the year, and it decomposes these changes into the four components discussed above. The mortgage-Treasury spread increased rapidly starting in late February, peaking at about 90bp above pre-pandemic levels in late March (seen in the black dots in the figure). The mortgage-Treasury spread then gradually normalized, but even in August it remained about 50bp higher than at the start of the year. The spread did not return to pre-pandemic levels until November 2020.

The decomposition in the figure shows that this rise in the mortgage-Treasury spread is more than entirely accounted for by a sharp increase in the primary-secondary spreadthat is, by a higher price of intermediation in the primary mortgage market. In contrast, the three financial market components (duration, option cost, and OAS) were actually lower than their pre-pandemic levels over most of 2020.

There were, however, some temporary effects of financial market disruptions during the flight to liquidity in March 2020. OAS increased sharply in March, reflecting an amplification of risk premia in financial markets as well as deleveraging by mortgage REITs. The option cost also increased, reflecting the rise in interest rate volatility. But these spikes were short-lived. On March 15, the Federal Reserve resumed its MBS quantitative easing program, and on March 23 it announced that it would purchase agency MBS in the volume needed to support market functioning. These actions are associated with a rapid normalization of OAS, which then fell below pre-pandemic levels. The duration adjustment also became negative after February 2020, reflecting a drop in the model-implied duration of newly originated mortgages (from 4.7 years in January to 3.2 years by July).

For comparison, panel B of Figure 2 presents the same decomposition of the mortgageTreasury spread over the June 2007-May 2009 financial crisis period, when the spread was similarly elevated. The figure shows that the sources of the elevated spread are very different between the two episodes. The primary-secondary spread barely moves during the financial crisis, and it is the spread on MBS in secondary financial markets, and particularly a rise in OAS, that accounts for the unusually high gap between mortgage rates and Treasury yields, at least until early 2009, when financial markets start to normalize.

Given these facts, our focus in this paper is on understanding the high markup in the 
primary mortgage market during the pandemic. But first we consider two alternative ways of measuring the markup: gain-on-sale and lender profit margins.

\section{III.C Measuring Intermediation Markups: Gain-on-Sale}

The primary-secondary spread examined above is appealing in the context of decomposing different factors affecting mortgage rates actually paid by borrowers. It is also frequently followed by policymakers and market commentators, thanks to its apparent simplicity. However, it has a few conceptual shortcomings, as discussed in detail in Fuster et al. (2013) and Fuster, Lo, and Willen (2017).

Most important, the primary-secondary spread does not accurately capture how banks and nonbank mortgage lenders think about the margin they earn from originating a mortgage that is securitized in the MBS market. Rather than "earning" the mortgage rate and "paying" the MBS yield over the life of the loan, originators earn most of their margin upfront, as the difference between the amount they receive from selling the loan in the secondary market and the amount paid to the borrower. The only relevant "flow" income over the life of the loan is the servicing strip (equal to 25bp per year in case of GSE loans, and 44bp for FHA loans). This can be earned by either the mortgage originator or another firm that acquires the right (and obligation) to service the loan. The value of the mortgage servicing right (MSR) is usually capitalized and incorporated in the calculation of the lender margin, which is often referred to as the "gain-on-sale."

Formally, consider a mortgage with initial balance $S_{0}$. Assume that time is continuous and the loan has constant prepayment hazard $\lambda_{p}$. Using the notation from above, the value of the loan is

$$
V=\int_{0}^{\infty} e^{-r_{s} t} S_{t}\left(r_{p}-g+\lambda_{p}\right) d t
$$

Assuming that the lender can sell the loan in the MBS market for $V$, the lender's profit, or "gain-on-sale," on the loan is $V-S_{0}$. With a constant prepayment hazard, $S_{t}=S_{0} e^{-\left(\lambda_{p}\right) t}$, and gain on sale can be expressed as

$$
\frac{V-S_{0}}{S_{0}}=\frac{r_{p}-r_{s}-g}{r_{s}+\lambda_{p}}
$$

The logic here is exactly as described above: The higher the prepayment hazard $\lambda_{p}$, the 
less profitable the loan (assuming $r_{p}-g>r_{s}$ ).

Equation (4) omits two components that are important in actual gain-on-sale calculations. First, lenders typically value the servicing flow $s$ separately from the rest of the cash flow. The net servicing income flow is $s\left(1-c_{s}\right)$, where $c_{s}$ is the cost of servicing as a share of servicing income. Second, the lender typically collects points and fees at origination, which we denote as $F$, so the initial cash outlay is not $S_{0}$ but $S_{0}-F{ }^{12}$ Taking those two factors into account, we can write gain-on-sale as

$$
\underbrace{\pi}_{\text {Gain-on-Sale }}=\underbrace{\frac{r_{p}-r_{s}-g-s}{r_{s}+\lambda_{p}}}_{\begin{array}{c}
\text { Secondary Market } \\
\text { Income }
\end{array}}+\underbrace{\frac{s\left(1-c_{s}\right)}{r_{s}+\lambda_{p}}}_{\begin{array}{c}
\text { Mortgage Servicing } \\
\text { Right (MSR) }
\end{array}}+\underbrace{\frac{F}{S_{0}}}_{\begin{array}{c}
\text { Points and } \\
\text { Fees }
\end{array}} .
$$

$\left(1-c_{s}\right) /\left(r_{s}+\lambda_{p}\right)$ is known as the servicing multiple. Similarly, $1 /\left(r_{s}+\lambda_{p}\right)$ for the first term can be seen as a valuation multiple used to value the "interest-only (IO)" strip provided by the numerator (paying a constant fraction of the unpaid principal balance of the loan while the loan is active and nothing when the loan prepays).

Our approach to measuring gain-on-sale follows Fuster, Lo, and Willen (2017). To compute the value of secondary market income, we assume that the lender sells the loan in the TBA market. ${ }^{13}$ Specifically, we start with $r_{p}-g-s$ and interpolate between the two nearest MBS coupons (for example, if $r_{p}-g-s=3.25$, we take the equal-weighted average price of a 3.0 coupon and a 3.5 coupon). To value the MSR, we use valuation multiples provided by SitusAMC, an independent valuation service company. These multiples are based on transaction values of brokered bulk MSR deals, surveys of market participants, and a pricing model, and capture the net value of servicing, that is, the value of the income flow minus expected costs. ${ }^{14}$ The multiples are provided to us at monthly frequency at the coupon-by-loan type (GSE versus FHA) level. ${ }^{15}$ All components are expressed per

$12 \bar{F}$ is net of loan-level price adjustments (LLPAs) paid to the GSE when selling the loan.

13 "TBA" stands for "to be announced," which is the MBS market where new agency mortgages are typically forward-sold. See Vickery and Wright (2013) for additional institutional details.

${ }^{14}$ Fuster et al. (2013) calculate a measure of $\pi$ called "OPUC," where they explicitly consider the choice of coupon into which a loan is securitized but for the most part assume constant multiples over time. In Internet Appendix A.2, we show that results using OPUC are qualitatively similar.

${ }^{15}$ Appendix Figure A.1 shows the evolution of these multiples for conventional conforming and FHA segments. Multiples for given fixed coupons decreased over time, reflecting the drop in market interest rates. However, the interpolated multiple at the typical coupon rate for new loans decreased only modestly before fully reverting over the course of 2020. 
$\$ 100$ loan amount, as is standard in the industry.

Figure 3 compares our estimates for intermediation markups based on the simple primary-secondary spread measure from Section III.A.1 and the gain-on-sale methodology from this section. Panel A shows the primary-secondary spread based on three different mortgage rate series, the PMMS survey rate (our baseline), the Mortgage Bankers Association (MBA) weekly application survey, and the Optimal Blue Insight data. ${ }^{16}$ Despite some differences across the three series, the primary-secondary spread increases significantly at the onset of the pandemic regardless of which mortgage rate is used. ${ }^{17}$

Panel B of Figure 3 shows time series of our estimates of gain-on-sale in the conforming market, based on the same three mortgage rate series. In all cases, gain-on-sale jumps by about $250 \mathrm{bp}$ from mid-February to early April 2020, and then stays high over the rest of the year. Based on the PMMS and MBA series, it is on average roughly 200 bp higher than in the second half of 2019; with the Insight series, the increase is around $175 \mathrm{bp}$. If we compare panels A and B of Figure 3, we see similar patterns, with the main difference being that the primary-secondary spread (panel A) reverts more toward its pre-pandemic level at the end of 2020 than gain-on-sale (panel B).

Gain-on-sale shows just how profitable mortgage lending was in the last three quarters of 2020. Originations over the period averaged more than $\$ 1$ trillion a quarter. Multiplying our quarterly gain-on-sale measures by origination volumes implies total industry gain-on-sale of about $\$ 162$ billion, or $\$ 54$ billion a quarter. Had gain-on-sale remained at its pre-pandemic level of 2.5 percent, the industry would have earned only $\$ 82$ billion over these three quarters-that is, half as much as it did.

\section{III.D Lender Profit Margins}

Direct evidence on intermediaries' loan production profits also indicates record-high margins. We obtain data from the Mortgage Bankers Association Quarterly Performance Re-

\footnotetext{
${ }^{16}$ The PMMS and MBA surveys ask lenders for both rates and discount rates offered. Since the discount points change each week, and there is a rate-point trade-off, the published survey rates are not directly comparable week to week. To address this, we use the point-rate trade-offs estimated in the Optimal Blue offer (Insight) data for 2017 through 2020 to adjust survey rates to a "constant discount points" rate. For previous years when Optimal Blue data are not available, we estimate these trade-offs using MBS prices.

${ }^{17}$ Internet Appendix Figure A.2 shows that the patterns are also qualitatively similar when we use the Current Coupon (CC) to measure for MBS yields. The CC yield is not as reliable in this time period, however, since every MBS coupon traded far above par in 2020. See Fuster et al. (2013) for a related discussion.
} 
port, which has been collecting quarterly data from roughly 340 mortgage banks on revenues and expenses since 2008:Q3 ${ }^{18}$ Panel A of Figure 4 plots the time series of average total net production income (in basis points of loan volume) reported by the firms in the sample-meaning the margin between loan production revenues and expenses. We note that mortgage banks do not necessarily capture the entire intermediation markup, as they often act as correspondent lenders for larger banks ("aggregators") that then sell the loans in the secondary market and also capture part of the markup.

Income in Q2 through Q4 of 2020 is extraordinary compared with all other quarters in the data. Net production income is about $60 \mathrm{bp}$ in 2020:Q1, already at the higher end of incomes over the previous few years, but it was more than three times as high, 203 $\mathrm{bp}$, in Q3. Furthermore, this higher net margin was earned on loan production that was almost twice as high. In panel B, we multiply the net production income by the average reported origination volume per firm, which was $\$ 1.335$ billion in Q3 and $\$ 1.472$ billion in $\mathrm{Q} 4$, versus $\$ 728$ million in Q1. The resulting total net production income therefore skyrocketed from below $\$ 5$ million in Q1 to an average of $\$ 21.4$ million over the remaining quarters of 2020, with a peak of more than $\$ 27$ million in Q3.

These data provide further confirmation that the price of intermediation in the mortgage market was historically high in 2020. They also show that high measured gain-onsale at least partly translated into high lender profit margins rather than being absorbed by expenses not accounted for in our gain-on-sale calculations. ${ }^{19}$ We now study the role of different economic factors in accounting for these strikingly high markups.

\section{Capacity Constraints}

We first examine whether industry capacity constraints can explain the high intermediation markups documented above. Individual loan officers and underwriters are limited in how quickly they can process mortgage applications, and lenders face significant adjustment costs in hiring and training new workers, particularly in the short run. Fuster et al.

\footnotetext{
${ }^{18}$ Note that the sample of reporting firms changes over time, and we have access to only aggregate series, not firm-level series. Also, these statistics are not specific to the conventional conforming segment; they combine all originations.

${ }^{19}$ For instance, Fuster et al. (2013) discuss pipeline hedging costs, which are proportional to implied interest volatility. However, while this volatility spiked early in the crisis, it has since been at or below its level of January and February 2020.
} 
(2017) find evidence that these constraints lead to an increase in mortgage markups during periods of peak demand-in other words, given limited capacity, lenders "step on the brakes" by increasing the margins charged to borrowers. ${ }^{20}$

\section{IV.A Is 2020 Consistent With Historical Patterns?}

Figure 5 studies whether the historical relationship between intermediation markups and capacity utilization can account for the high markups in 2020. The figure plots mortgage demand against two measures of intermediation markups we have used already: the primary-secondary spread and the gain-on-sale $(\pi)$. Our preferred proxy for demand is the difference between the weighted average coupon (WAC) on the stock of mortgages and the 10-year Treasury yield. This measure is highly correlated with applications for (refinance) loans and is arguably exogenous to current mortgage supply shocks, because it does not rely on current mortgage rates. ${ }^{21}$ We also use the MBA mortgage applications index as an alternative direct measure of demand.

The figure shows that the price of intermediation during the pandemic significantly exceeds what would be predicted simply based on the level of demand. Red squares in Figure 5 are from 2020, with the number indicating the month of the observation. Blue circles are from 2012 through 2019. There is a clear positive historical relationship between markups and mortgage demand. But from about April 2020 onward, markups are well above the line of best fit, regardless of which demand or markup measure is used.

Table 1 quantifies the "excess" markup by regressing the primary-secondary spread or gain-on-sale on either of the mortgage demand proxies and time dummies corresponding to different phases of the pandemic. In all cases, the pandemic dummies indicate large, statistically significant excess markups from March 2020 onward. The historical relation between markups and demand can account for only about 20 to 40 percent of the rise in

${ }^{20}$ Consistent with the presence of capacity constraints, Fuster et al. (2017) show that loan processing times are strongly positively correlated with mortgage application volumes. Sharpe and Sherlund (2016) also find evidence of capacity constraints, showing that refinancing waves induce substitution away from complex mortgages that are more labor intensive to process and underwrite.

${ }^{21}$ In contrast, using the difference between WAC and the current mortgage rate may produce bias in the estimated markup relationship, because mortgage rates reflect the intersection of demand and supply (Fuster et al., 2017). The WAC-10-year Treasury spread is highly correlated with an estimate of the percentage of active mortgage borrowers who are refinance candidates (from Lambie-Hanson, 2020), measured in either monthly levels $(\rho=0.77)$ or monthly changes $(\rho=0.70)$ from January 2008 through October 2020. 
intermediation markups, depending on the specification..$^{22,23}$

Column 1 shows that the primary-secondary spread is $77 \mathrm{bp}$ higher than expected in March through May, and 86 bp higher in June through August (that is, it increased an additional $9 \mathrm{bp}$ ). By comparison, the one-standard-deviation residual from this regression excluding the COVID-19 period is only $8.9 \mathrm{bp}$ (last row of table). Thus, one could consider the COVID-19 period roughly a "9 sigma" event that persists for well over six months. Results are similar in column 2, although the regression fit is slightly weaker. The excess intermediation markup is also highly significant when we use gain-on-sale as the dependent variable (columns 3 and 4). Gain-on-sale is $\$ 1.05$ to $\$ 1.30$ higher than expected over March through May, rising to $\$ 1.40$ to $\$ 1.60$ over June through August. ${ }^{24}$

\section{IV.B Operational Constraints in Expanding Capacity}

We now document several pieces of evidence suggesting that operational issues related to the pandemic made it more difficult for lenders to expand capacity in 2020. This provides a plausible explanation for why the mortgage supply curve was unusually inelastic relative to previous lending booms.

\section{IV.B.1 Labor Market Frictions}

Anecdotal evidence suggests the remote-work environment created significant challenges in hiring, training, and onboarding new loan officers, processors, and other mortgage employees. One leading industry participant told us that it has been difficult to train new

${ }^{22}$ On the high end of this range, the coefficient in column 4 would project a maximum increase in gain-onsale of $109 \mathrm{bp}$, given that the MBA applications index increased from an average of 449 in January 2020 to a maximum of 1002. This compares with an actual increase in gain-on-sale of $279 \mathrm{bp}$.

${ }^{23}$ The pandemic dummies from March through August are comparatively smaller for gain-on-sale than for the primary-secondary spread, considering that the latter is a flow measure while the former measures the total gain earned by intermediaries. This reflects (i) a flattening of the relationship between gain-on-sale and the primary-secondary spread during the pandemic, and (ii) the fact that gain-on-sale is below the line of best fit at the start of 2020, while the primary-secondary spread is close to its fitted value.

${ }^{24}$ Our estimates could overstate gain-on-sale if the SitusAMC servicing multiples fail to properly reflect the risks for servicers of elevated forbearance and non-payment. But in Section V.A we show there is no evidence of a rising interest rate premium for high-risk conventional conforming loans during the pandemic, which speaks against this hypothesis. We also have no reason to doubt that the SitusAMC valuations internalize the risks of forbearance; in fact, given secondary market illiquidity for MSRs, transactions may understate going-concern values if they mainly reflect forced sales at fire-sale prices. Finally, even if we set the servicing multiple to zero- a very extreme assumption-this would reduce gain-on-sale by only about $\$ 1$, still not bringing it fully in line with historical patterns. 
employees and to monitor their work, and that as a result lenders prioritized hiring experienced professionals (generally from competitors) who were well known and trusted and did not require much training or supervision. Consistent with this message, an executive at large nonbank lender Mr. Cooper explained their limited expansion in capacity as follows: "It reflects the fact that we add capacity at a deliberate pace with an eye on the long term. And additionally, when the crisis hit and we shifted to work-from-home status, that slowed our hiring and our onboarding" (Ivey, 2020). The diversion of staff and managerial attention to process the wave of forbearance applications appears to have been an additional drain on the effective labor supply, at least early in the pandemic (Berry and Kline, 2020).

Disruptions to the licensing of mortgage loan officers also held back growth in labor supply. Nonbank loan officers must be licensed through the Nationwide Multistate Licensing System (NMLS), a process including background checks, fingerprinting, an examination, and ongoing education. ${ }^{25}$ During the early months of the pandemic, half of the fingerprinting locations were shuttered, and about 10 percent remained closed as of December 2020. Testing sites also closed in the early months, although the NMLS began offering a remote testing option in September. These factors limited the inflow of de novo loan officers and also affected employees switching from banks to nonbanks or changing their state of employment. ${ }^{26}$

This qualitative evidence suggests that the supply of labor was relatively inelastic during the pandemic, which would imply unusually slow hiring compared with the level of labor demand and also a sharp increase in the price of labor. We now present evidence supporting these predictions.

Panel A of Figure 6 shows that lenders added nearly 50,000 mortgage loan officers and underwriters (MLOs) after the emergence of COVID-19 in March 2020. This took MLO employment to a post-financial crisis high of 360,000, although employment remained 120,000 MLOs short of its all-time peak in 2004. Data from Burning Glass in panel A

${ }^{25} \mathrm{~A}$ new license is required not just for de novo loan officers, but also for experienced loan officers transitioning from banks to nonbanks or moving across states. In the latter two cases, the loan officer is permitted to temporarily operate for 120 days before obtaining a new license (Mortgage Bankers Association, 2019). We were told, however, that in some cases licensing delays exceeded this 120 day grace period.

${ }^{26}$ In an email communication, one industry participant told us, "Testing centers closed at times and have had limited availability. This has prevented new LOs [loan officers] from joining the industry right away. We have seen delays of anywhere from a few weeks to a few months depending on the restrictions in the area." 
also show a sharp rise in MLO job postings during the COVID-19 period. ${ }^{27}$ Postings fluctuated around 1 vacancy per 100 employees prior to COVID-19, but jumped to more than 2 per 100 during the pandemic.

To test whether MLO hiring was low relative to the number of postings, we estimate the following regression:

$$
\log \left(M L O_{t+1}\right)-\log \left(M L O_{t}\right)=\alpha+\beta_{1} p_{t}+\beta_{2} p_{t-1}+\beta_{2} p_{t-2}+\varepsilon_{t}
$$

where the dependent variable is the log change in MLO employment between mid-month $t$ and mid-month $t+1$ (from the BLS Current Employment Statistics, Establishment Survey) and $p$ are monthly MLO postings per employee from Burning Glass. The regression is estimated on data from March 2012 through February 2020. Coefficients are shown in Internet Appendix Table A. 1 and imply a correlation of about 0.5 between actual employment growth and employment growth predicted just by current and lagged job postings.

Panel B of Figure 6 presents predictions from this regression model that illustrate how anomalous the pandemic period was for the hiring-vacancies relationship. Dots labeled "COVID" are out-of-sample predictions for March 2020 through December 2020. Actual employment growth fell short of the predicted value in all 10 months. Overall, we estimate that monthly employment growth averaged about 1.5 percentage points less than we would expect. In panel A, the line labeled "Counterfactual Employment" quantifies the cumulative effect of this hiring gap. Actual MLO employment at the end of 2020 was 60,000 lower than what would be predicted based on the historical relationship between postings and employment growth.

Turning to the cost of labor, it is difficult to observe the compensation packages offered to loan originators, which often involve a combination of a signing bonus, fixed salary, and loan volume incentives. Nevertheless, available data from the Mortgage Bankers Association, analyzed in Appendix B.2, are consistent with a significant increase in labor

\footnotetext{
${ }^{27}$ Burning Glass Technologies is an employment analytics and software company that crawls more than 40,000 online job boards and company websites daily, scraping and cleaning information on job postings. We focus on job postings with the $\mathrm{O}^{*} \mathrm{NET}$ job code 13-2072, which includes professionals who evaluate, authorize, or recommend approval of commercial, real estate, or credit loans, including mortgage loan officers and agents, collection analysts, loan servicing officers, loan underwriters, and payday loan officers. We further capture "mortgage loan officers" as postings in this category that have the words "mortgage," "mtg," "home," or "residential" in the job title.
} 
costs during the pandemic. Labor costs per dollar of loan volume typically fall significantly during lending booms due to scale economies; but we show labor costs declined only slightly during the 2020 boom. A conservative estimate is that personnel expenses scaled by loan volume were unusually high by at least 25 bp by 2020:Q4, equivalent to more than 10 percent of average personnel costs measured over the previous five years.

\section{IV.B.2 Operational Issues in Mortgage Origination}

The pandemic also made the process of originating a mortgage more complex and uncertain. Obtaining documentation of borrower employment and income was often challenging because many businesses were physically closed, and the high rate of job loss often required checking employment status multiple times before closing (Berry and Kline, 2020). County recorder offices were closed or operating on limited schedules, making it hard to complete title searches and causing delays in recording mortgages, which in turn raised concerns about the potential for fraud (Hughes, 2020). Other steps in the process, such as property appraisals and obtaining notarized signings of closing documents, were more cumbersome due to social distancing. For example, Michael Fratantoni of the Mortgage Bankers Association noted that "there are steps in the process that are still physical, like the actual mortgage note. If it's a paper note, someone still has to show up at the office and collect those and send it on to the next step in the process." (Berry and Kline, 2020)

\section{IV.C Technology and Capacity Constraints}

The mortgage industry has undergone significant technological change in recent years. Did technology play a role in expanding lending capacity and mitigating operational and labor market frictions during the pandemic? For instance, information technology can enable the origination process to be less labor intensive and more automated and thereby more scalable, consistent with Fuster et al.'s (2019) finding that technology-based mortgage lenders adjust processing capacity more elastically. ${ }^{28}$ Technology-based lenders are also likely to rely on digitized records rather than paper documents and be able to transition their workforce more easily to remote work. It is also possible that borrowers placed more value on a high-quality online platform during the pandemic, given the challenges

\footnotetext{
${ }^{28}$ Rocket Mortgage CEO Jay Farner emphasized this scalability in the context of the 2020 refinancing wave in the firm's 2020:Q3 earnings call, as reported by industry newsletter HousingWire: "Farner also said Rocket was able to scale more aggressively than competitors due to its tech stack and business model, which he said is far more efficient because it doesn't require disproportionately high headcounts." (Kleimann, 2020).
} 
of face-to-face interactions and the transfer of physical documents. ${ }^{29}$

We use loan-level data from eMBS and the classification of "fintech" lenders from Fuster et al. (2019) to assess whether technology-based lenders expanded lending more rapidly during the pandemic. ${ }^{30}$ We investigate two questions. First, did fintech lenders increase their overall market share? Second, did they gain market share particularly for mortgages that are complex and time intensive to underwrite? This second test is motivated by Sharpe and Sherlund (2016), who find that capacity constraints induce lenders to ration credit by prioritizing simpler and less labor-intensive mortgage applications. Following Sharpe and Sherlund, we use low-credit-scores and purchase mortgages as two measures of these more complex-to-underwrite loans.

We estimate linear probability models in which the dependent variable is a dummy equal to 1 if the originator is a fintech lender in the Fuster et al. (2019) classification. The right-hand-side variable of interest is a pandemic dummy equal to 1 for mortgage applications underwritten and processed during the pandemic, which, given the time to close a loan, we proxy by an origination date after March 2020. The model is estimated using loan-level eMBS data on agency mortgage originations, combining data from Fannie Mae, Freddie Mac, and Ginnie Mae. The sample period is January 2019 through December 2020. Like Fuster et al. (2019), our main specifications exclude bank loans, to isolate differences between fintech lenders and other nonbank lenders with a similar funding model and common regulatory environment.

Results in Table 2 indicate an increase in the fintech market share during the pandemic, concentrated among complex loans. Columns 1 through 3 focus on purchase mortgages, which are typically more complicated and labor intensive to underwrite than refinancings. In column 1, which includes no controls (that is, a simple difference in means) the fintech share is 2.8 percentage points higher during the pandemic than in the pre-pandemic period (defined as loans closed from January 2019 through March 2020). Column 2 controls

${ }^{29}$ For example, Rocket Mortgage CEO Farner claimed during the company's third quarter earnings call that "[d]emand for a completely digital experience has never been stronger and Rocket is delivering." (Kleimann, 2020).

${ }^{30}$ The Fuster et al. (2019) classification identifies six mortgage lenders that offered a fully online application as of the end of 2016: Rocket (Quicken Loans), Better Mortgage, Guaranteed Rate, LoanDepot, Movement Mortgage, and Supreme Lending (Everett Financial). Online lending platforms were much more ubiquitous in 2020 than in 2016, but this set of lenders has remained near the technology frontier. Relying on this list also limits the influence of look-back biases or subjective judgments about which lenders are technology leaders today, because the Fuster et al. (2019) classification was set well before the start of the pandemic. It does, however, mean we miss some technology-based lenders that have emerged more recently. 
for state fixed effects (the most granular geographic information in these data) as well as loan and borrower characteristics such as quadratic functions of credit score, debtto-income, and loan-to-value (see table notes for full list of controls). The coefficient is somewhat smaller, at 2.1 percentage points, but remains statistically and economically significant. Quantitatively, the increase is about one-fifth of the sample mean of 11.1. Column 3 includes a pandemic $\times($ credit score $<680)$ interaction term, which indicates that the rise in fintech share is significantly larger for low-credit-score mortgages. The total effect for these loans is about 4.1 percentage points.

The next three columns focus on refinancings, the sector where fintech lenders historically have specialized. Interestingly, the overall fintech share of refinancings is little changed during the pandemic, although again the fintech share does rise for low-creditscore borrowers, as shown by the positive interaction term in column 6 . The final three columns are based on a pooled sample including both purchase mortgages and refinances. The increase in the fintech lenders' overall share reflects their gains in the purchase market as well as a compositional shift in lending toward refinancings.

In Internet Appendix $C$, we trace out the timing of these changes by replacing the pandemic dummy with monthly time dummies and plotting the resulting coefficients. The purchase-mortgage graph is particularly striking: The fintech market share is very stable at about 7 percent prior to the pandemic, but then it jumps sharply by about 3 percentage points as the pandemic takes hold, before declining later in 2020 as conditions start to normalize. ${ }^{31}$ As an additional robustness test, we re-estimate the analysis in Table 2 while retaining bank lenders in the sample. The results (also presented in Internet Appendix C) are similar to our main estimates.

These results support the view that technology and automation helped the mortgage industry manage the capacity constraints and operational challenges associated with the pandemic. In particular, the fintech market share increased most markedly for purchase mortgages and loans to low-credit-score borrowers, exactly those loans which are typically de-prioritized during periods when capacity constraints bind (Sharpe and Sherlund, 2016).

${ }^{31}$ We investigate the composition of this increase in the fintech share, finding that it is broadly based across the set of six firms classified as technology-based lenders. 


\section{Alternative Explanations: Risk, Health and Competition}

We now consider several other plausible drivers of the rising price of intermediation for conforming mortgages, related to default and forbearance risk, the direct health and economic effects of the virus, and lender market power. The evidence we present below suggests that none of these factors played an important role in accounting for the high markups in 2020.

\section{V.A Forbearance and Default Risk}

The pandemic led to a surge in mortgage forbearance and non-payment, reflecting high unemployment and a CARES Act provision requiring servicers to provide up to a year of forbearance on federally backed mortgages. ${ }^{32}$ Non-payment is costly for mortgage lenders and servicers, even in the conforming market where loans are securitized and carry a credit guarantee. First, there is liquidity risk because the servicer is required to advance mortgage payments, taxes, and insurance even if the borrower stops paying. These advances will eventually be reimbursed, but funding them in the interim may be expensive or infeasible. ${ }^{33}$ Second, there is "pipeline" risk that the loan becomes nonperforming just after origination, before it can be sold. ${ }^{34}$ Third, servicing a delinquent loan is much more labor intensive and costly.

We use the cross section of mortgage rates to study whether this heightened default risk led to a risk premium that increased mortgage rates for borrowers. Our approach uses the fact that the rate of non-payment was much higher for low-credit-score borrowers (see Internet Appendix E for evidence based on McDash servicing data). If rising default risk is being priced into conforming mortgage rates, we should see an increase in the interest rate spread between low- versus high-score conforming mortgages.

${ }^{32}$ At the peak in June 2020, 8.6 percent of all mortgages were in forbearance (source: Mortgage Bankers Association). The total mortgage non-payment rate more than doubled during the early part of the pandemic: from 3.2 percent in January 2020 to 7.8 percent by May 2020 (Black Knight Financial Services, 2020).

${ }^{33}$ This was a cause of great concern in the industry early in the pandemic. On April 21, 2020, it was announced that servicing advances for conforming mortgages securitized by Fannie Mae and Freddie Mac would be capped at four months of principal and interest (Federal Housing Finance Agency, 2020). This cap does not apply to taxes, insurance, and other payments.

${ }^{34}$ Such loans typically would be sold privately at a significant discount. The GSEs and FHA took some steps to limit pipeline risk during the pandemic, but these steps only partially protected lenders (for example, the GSEs agreed in April 2020 to purchase loans in forbearance, but only at a 500-700bp discount: See https://bankingjournal .aba.com/2020/04/fhfa-to-purchase-qualified-loans-in-forbearance.) 
We first estimate this default risk spread using Optimal Blue Insight data on mortgage offers from lenders. Our data include offer rates for otherwise identical mortgages with a FICO score of both 680 and 750. We measure the rate premium for a FICO 680 loan by estimating the regression:

$$
\text { rate }_{i m t}=\alpha_{m t}+\beta_{t} \times\left(\mathrm{FICO}_{i}=680\right)+\varepsilon_{i m t},
$$

where rate imt $_{i}$ is the interest rate on an offer $i$ in CBSA $m$ during week $t, F I C O_{i}=680$ is a dummy for a FICO score of 680 rather than 750 , and $\alpha_{m t}$ are CBSA $\times$ week fixed effects. Other loan characteristics are held fixed (e.g., DTI $=36, \mathrm{LTV}=80$ and balance of $\$ 300 \mathrm{~K})$. $\beta_{t}$ then traces out the evolution of the FICO 680-750 interest rate spread.

We also compute an analogous spread using Optimal Blue rate locks data, estimating:

$$
\text { rate }_{i l m t}=\alpha_{m t}+\delta_{l t}+\beta_{t} \times \text { FICO bin } i+\Gamma X_{i l m t}+\varepsilon_{i l m t},
$$

where rate $e_{i m t}$ is the interest rate on lock $i$ issued by lender $l$ in CBSA $m$ during week $t$; FICO bin $_{i}$ is a set of five FICO bin dummies; $\alpha_{m t}$ and $\delta_{l t}$ are CBSA $\times$ week and lender $\times$ month fixed effects; and $X_{i l m t}$ is a set of loan and borrower controls including log loan amount, DTI and DTI squared, and dummies for the lock period and property type. For loans with discount points or credits, we convert the lock rate to a zero-points equivalent interest rate using the market rate-point trade-off measured each week in Optimal Blue Insight. ${ }^{35}$

Estimates of $\beta_{t}$ from these two models are reported in the top two panels of Figure 7. There is no evidence of a persistent increase in the interest-rate spread on low-FICO mortgages, for either mortgage offers or rate locks. The interest rate spread does spike temporarily in March 2020, associated with the onset of the pandemic and dislocation in the MBS market. But by April, the interest rate spread returns to a narrow band around or even slightly below the pre-pandemic levels of about $40 \mathrm{bp}$.

\footnotetext{
${ }^{35}$ Borrowers pay discount points to buy down the interest rate on their mortgage. Conversely, mortgages with net credits have higher interest rates. The shape of the trade-off between rates and net points moves over time and has become flatter since the onset of the pandemic. Our Optimal Blue Insight data include daily offered interest rates for loans with different numbers of net points $(+2,+1,0,-1$, and -2$)$. We use this pricing grid to adjust the interest rate on each loan to an equivalent zero-point loan. We then use this adjusted rate as our dependent variable. An alternative approach is to include additional controls interacting points and credits with time dummies; this generates similar results.
} 
Data on quantities paint a similar picture. Panel $\mathrm{C}$ of Figure 7 plots the number of conforming lenders offering mortgages to borrowers with different FICO scores, calculated by averaging the number of rate offers in the Optimal Blue Insight data across the 20 CaseShiller metropolitan statistical areas (MSAs). The number of lenders drops temporarily in March, and more so for lower FICO loans, but it is subsequently quite stable, and there is no evidence of significant rationing to low-credit-score borrowers. Panel D plots the percentage of conforming rate locks below two FICO thresholds (680 and 640). For purchase mortgages (the two solid lines), there is no evidence of a drop in the percentage of low-FICO rate locks. There is a drop for refinances, but this is typical during a refinancing boom because high-credit-score borrowers have a greater propensity to refinance when rates fall (e.g., Keys et al., 2016)

This evidence suggests that heightened default risk is not an important reason for the high markups on prime conforming mortgages during the pandemic. Default risk is more important for rates in the high-risk FHA market, however, as we show in Section VI.

\section{V.B Macroeconomic and Health Shocks}

Although we find little role for individual default risk, perhaps intermediation markups incorporate a more general premium due to the macroeconomic and health shocks associated with the virus. In such a case, we might nevertheless expect to see heterogeneity, but primarily across locations, depending on how severely the locality is affected by the spread of the pandemic and drop in economic activity.

In Table 3, we examine variation in locked rates across the 100 most populous metro areas. We regress loan-level interest rates (adjusted for points) from 1.1 million conventional conforming loans locked from November 2019 through August 2020 on metro area fixed effects, loan characteristics (e.g., loan-to-value ratio, credit score) interacted with week locked, and different proxies for how severely a metro area was affected by COVID19 , in terms of both the economic and health impacts.

The first variable we try is COVID-19 cases per 1,000 metro area residents in the preceding calendar month. Since this variable equals 0 everywhere prior to February 2020, the preceding months provide our "pre-period." In fact, higher local case numbers are associated with slightly lower mortgage interest rates (column 1). The effect is extremely 
small, however-a one-standard-deviation rise in case rate is associated with only a 0.3 bp drop in mortgage rates. Results are similar if we instead use a dummy for metro areas in the top quartile of cases per capita (column 2).

Next we study the economic shock. Job losses, measured as the standardized yearover-year change in the local unemployment rate, are positively correlated with mortgage rates, although again the effect is not economically meaningful. A one-standard-deviation increase in the unemployment rate is associated with a $1.2 \mathrm{bp}$ increase in mortgage rates. The aggregate increase in unemployment (from 3.5 percent to a peak of 14.8 percent nationally) would correspond to 2.7 standard deviations, or a rate impact of about $3 \mathrm{bp} .{ }^{36}$

\section{V.C Competition}

Table 3 also examines whether imperfect competition may help explain the rise in markups, motivated by Scharfstein and Sunderam (2016), who find lower mortgage rate pass-through in concentrated markets. Using two measures of market concentration interacted with a COVID-19 dummy (= 1 from March 14, 2020, onward), we find no evidence that concentration reduced pass-through of lower rates during this episode. In column 4 , the concentration measure is the share of mortgages originated in 2019 by the metro area's top four lenders, while in column 5 it is the local Herfindahl-Hirschman Index (HHI). Both measures are derived from 2019 HMDA data and standardized to a mean of zero and a standard deviation of one. Neither interaction term is statistically significant, and the confidence bounds exclude any economically significant effect. ${ }^{37}$

We also consider the possibility that the pandemic itself reduced competition and thereby led to higher markups. Detailed updated measures of local concentration are not yet available, but national data provide no support for this hypothesis-in fact, the market share of the largest lenders if anything decreased in Q2 and Q3 of 2020, as we document in Internet Appendix Figure A.11 based on data from Inside Mortgage Finance.

${ }^{36}$ Our sample in Table 3 runs through August 2020. We choose to focus on the early part of the pandemic, when the primary-secondary spread was at its largest and the unemployment rate was high, to gauge an upper bound on the impact of the economic shock. The unemployment effect is even smaller if we extend the sample through the end of 2020.

${ }^{37}$ As shown in column 6, the results of Table 3 remain similar if we consider a multivariate specification including interactions for the virus spread, unemployment, and concentration together. In Internet Appendix Table A.4, we also estimate the same models using an alternative data set of conventional conforming loans, the $\mathrm{McD}$ ash data. Again we find little relationship between interest rates and either virus spread or market concentration, and the effect of unemployment is also insignificant (with a negative point estimate). 
In short, the rise in mortgage spreads during the pandemic is a national phenomenon, and is not significantly related to the degree of virus spread, the depth of the economic crisis, or local market concentration. Consistent with these findings, Internet Appendix Figure A.12 shows, based on Optimal Blue data, that although mortgage rates do vary across metro areas, the differences are generally small, and from early 2019 through late 2020 , the rank ordering of metro areas is quite persistent.

\section{V.D Shopping}

Even if there are many lenders, each originator may enjoy market power if borrowers do not search extensively (e.g., Wolinsky, 1986). It is also possible that borrowers search less actively during refinancing booms, because they do not need to scour the marketplace to beat their current rate, which could increase lenders' bargaining power (see Bhutta et al. 2021 for some direct evidence on this point). However, mortgage search activity appears to have been extremely high during the pandemic. Google Trends data in panel A of Figure 8 indicate that web searches for refinance-related terms spiked in March and remained elevated thereafter. As shown in panel B of Figure 8, borrower search activity was also unusually high relative to what would be predicted based on the level of refinance incentives, measured by the WAC-10-year spread as in our earlier analysis.

Also speaking against a "low search intensity" hypothesis, servicer retention-the share of borrowers refinancing through their existing servicer-decreased during the pandemic. In 2020:Q3, only 18 percent of borrowers who refinanced remained with their previous servicer, the lowest rate for at least 15 years (Black Knight Financial Services, 2020).

\section{Credit Supply in Riskier Market Segments}

So far our analysis has focused on prime conforming mortgages. We now turn to other segments-the FHA market and the jumbo market- that present additional risk and com-

plexity for intermediaries. Studying these riskier segments and comparing them with the conforming market sheds light on two questions: (1) Did the spike in forbearance and default risk reduce credit supply for the riskiest borrowers and those not eligible for government guarantees; and (2) did Federal Reserve policy intervention through the resumption of MBS quantitative easing support mortgage credit supply? 


\section{VI.A Default Risk and Credit Guarantees}

\section{VI.A.1 The FHA Market}

We previously showed that the rise in forbearance and non-payment risk had little effect on prime conforming mortgage rates. But now we revisit this question for the FHA market, where mortgage intermediaries are significantly more exposed to default risk. This is because FHA borrowers default at much higher rates, and because institutional features of the FHA market shift more risk to the lender and servicer (Kim et al., 2018). ${ }^{38}$ For instance, servicers are obligated to advance payments on past-due mortgages until termination or modification, and they face significant delays before being reimbursed. ${ }^{39}$ The liquidity risk of servicing advances is particularly acute for the nonbank mortgage companies that now dominate FHA lending, because these nonbanks are financed by short-term debt and cannot issue insured deposits or access government liquidity backstops. ${ }^{40}$

First we estimate cross-sectional differences in interest rates between FHA borrowers with lower versus higher default risk. We proceed using the same methodology as in Section V.A, first analyzing interest rates on mortgage offers and rate locks, and then studying quantities. For interest rates, we focus on the rate difference between borrowers with a credit score of 640 versus 680. A credit score of 680 is typical for FHA loans (roughly at the 60th percentile in the first quarter of 2020), while 640 is roughly at the 20th percentile. $^{41}$

Results in Figure 9 show a clear increase in the interest-rate premium for the riskiest FHA borrowers. Panel A traces the evolution of the FICO 640-680 interest rate spread in

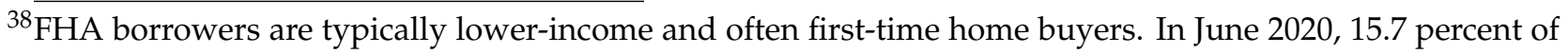
FHA loans were 60 or more days past due, compared with only 6.7 percent of conventional loans. (Source: 2020:Q2 MBA delinquency survey.)

${ }^{39}$ The FHA servicer is also not fully compensated for foreclosure costs. Tozer (2019) estimates that uncompensated costs are about $\$ 10,000$ per FHA claim. To limit liquidity outflows, the FHA determined that loans that re-perform after exiting forbearance can be made current by issuing a partial claim, reimbursing the servicer for principal and interest advances during forbearance. The FHA also created a temporary liquidity facility for servicers.

${ }^{40}$ Urban Institute (2021) calculates that in December 2019, 90 percent of Ginnie Mae mortgages were originated by nonbanks, and the nonbank share had increased to 93 percent by December 2020.

${ }^{41}$ Internet Appendix Figure A.16 displays the credit score distribution of FHA originations over the 20192020 period. Other assumptions for the offer data are that we study 30-year purchase-money FRMs with zero points, LTV = 95 to 97 percent (which is by far the most common in the FHA segment), and DTI of 36 percent. 
the offer data. The spread is stable at about $20 \mathrm{bp}$ before the pandemic, but it rises sharply beginning in April 2020, coincident with the post-CARES Act surge in forbearance. The spread peaks at about $70 \mathrm{bp}$ in June, $50 \mathrm{bp}$ above pre-pandemic levels. The spread then decreases and displays some volatility, but it remains elevated through to December 2020. The low-FICO spread also increases in the locks data (panel B of Figure 9), although the peak increase is only about $25 \mathrm{bp}$, compared with $50 \mathrm{bp}$ in the offer data. ${ }^{42}$

Data on quantities are also consistent with a decline in credit supply to high-risk FHA borrowers. Panel $\mathrm{C}$ of Figure 9 shows that the number of lenders offering any FHA mortgages drops by one-quarter during the market volatility in March 2020. In the highest risk segment (640 FICO) the number of lenders then falls further in April, to half the prepandemic level, even though lenders re-enter the market for lower risk loans. Lenders gradually return to the FICO 640 segment later in 2020. Similarly, Panel D shows that the share of FHA purchase rate locks to borrowers with a FICO score lower than 640 drops from 30 percent before the pandemic to less than 15 percent in April, coincident with the spike in rate spreads and drop in the number of lenders. ${ }^{43}$ Notably there is no similar decline for FHA refinances. For an FHA issuer, refinancing an existing customer does not present additional risk, because the issuer is already responsible for advancing payments if the borrower defaults. ${ }^{44}$

So far we have focused on variation in risk within the FHA market. Section A.4 in the Internet Appendix instead compares markups on FHA loans with less risky prime conforming loans. We indeed find that both the primary-secondary spread and gain-onsale increased by larger amounts for FHA mortgages, consistent with an amplification of the risk premium associated with FHA lending.

\footnotetext{
${ }^{42}$ This difference between offers and equilibrium outcomes may reflect heterogeneity in supply responses across lenders-e.g., a subset of risk-averse lenders post very high rates for low-FICO loans, but these lenders comprise only a small share of locks because their uncompetitive rates mean that few borrowers choose them. We see a similar pattern in the jumbo results in the following section.

${ }^{43}$ As the figure shows, the fraction of loans to lower-than-680 FICO borrowers also falls but by a smaller amount. We also find similar patterns for quantities using McDash origination data-see Figure A.16 in the Internet Appendix. The timing of the drop in low-credit-score lending is less sharp in McDash than Optimal Blue, however, which we interpret as being due to the variable time lag between the lock date and origination date (recalling that McDash reports only the latter).

${ }^{44}$ In fact, refinancing may even reduce risk by lowering the borrower's monthly payment (Fuster and Willen, 2017). Furthermore, a large majority of FHA refinances occur under a streamlined refinancing program that waives many requirements, including the need to conduct a property appraisal. Thus, operational issues related to the pandemic would disproportionately affect the FHA purchase market.
} 


\section{VI.A.2 The Jumbo Market}

Jumbo mortgages are large loans exceeding the conforming limits for agency securitization. Although jumbo borrowers typically have high incomes and credit scores, jumbos are relatively risky for lenders and investors (usually banks) because they do not carry government-backed credit guarantees. Comparing jumbo and conforming loans therefore sheds light on whether these guarantees stabilized credit supply in the pandemic.

We use Optimal Blue data to estimate the interest rate spread on jumbo mortgages compared with smaller but otherwise identical conforming mortgages, following our earlier methodology. Results are presented in Figure 10.

Panel A plots the jumbo-conforming offer rate spread for a mortgage with LTV of 80 and credit score of 750. Prior to the pandemic, jumbos carried an interest rate premium of 10-25 bp. This spread then increases sharply, to 80-100 bp from April through August 2020 , before declining to about $50 \mathrm{bp}$ by the end of 2020 . The estimated spread based on rate locks (Panel B) follows a similar pattern, from 0-10 bp to a peak of 40-50 bp from April through August, then a decline to about 30 bp by December. ${ }^{45}$

Panel B of Figure 10 plots the interest rate premium on "superconforming" (also known as "conforming jumbo") mortgages. These are loans that exceed the national conforming loan limit but are eligible for agency securitization because they are located in a county with a higher local limit (Vickery and Wright, 2013). ${ }^{46}$ Superconforming loans are somewhat less liquid and are also less likely to be purchased by the Federal Reserve in its quantitative easing program, as we discuss in Section VI.B. Including superconforming $\times$ time dummies in the rate locks regression model, we find that the superconformingconforming spread does indeed rise early in the pandemic, from 10-20 bp to 30-35 bp, coincident with the period of significant Fed MBS purchases. The spike in the spread is only temporary, however; it falls back to near-normal levels by mid-June.

We also find a reduction in the volume of jumbo lending. The number of lenders of-

\footnotetext{
${ }^{45}$ We also see a rise in the jumbo-conforming spread in time-series rate data from Mortgage News Daily and the Mortgage Bankers Association-see Figure A.18 in the Internet Appendix. Insight data also indicate a large increase in the jumbo-conforming spread for 5/1 ARMs.

${ }^{46}$ Fannie Mae and Freddie Mac may not purchase or securitize mortgages exceeding the relevant conforming loan limit. The national conforming limit ( $\$ 510,400$ in 2020 for a single-family home) applies in most counties, but the limit is higher in counties with high home prices, up to $\$ 765,600$ in 2020 . Superconforming mortgages are loans for amounts between the national limit and these higher local limits.
} 
fering jumbos to FICO 750 borrowers on the Optimal Blue platform drops by more than half in the early stages of the pandemic (Panel C of Figure 10), before slowly recovering to about 20 percent below pre-pandemic levels by December 2020. For lower FICO borrowers (680 and 640) the number of active lenders collapses almost to zero. By contrast, the number of lenders in the conforming market remains fairly steady, as shown earlier in Figure 7. The volume of jumbo locks as a fraction of all rate locks declines by about half, both for purchase loans and refinancings (panel D), before recovering.

This evidence is consistent with a negative supply response, but an important caveat is that Optimal Blue primarily reflects mortgages originated by nonbanks. Banks have a strong presence in the jumbo market, and several large banks stopped purchasing jumbos from nonbanks during the pandemic (Eisen, 2020). A potential concern is that the drop in quantity we observe simply reflects substitution in lending from nonbanks to banks.

For a more representative picture of the jumbo market, we turn to McDash loan-level data, which have good coverage of both banks and nonbanks. We estimate linear probability models in which the dependent variable equals 1 for a jumbo loan, using McDash loans within a 10 percent window around the applicable conforming loan limit (the national limit, or the relevant higher local limit for mortgages in high-cost counties). The key explanatory variable is a pandemic dummy equal to 1 from April 2020 onward.

Results in panel A of Table 4 show a significant decline in the fraction of jumbo loans, of about 7 to 8 percentage points compared with a sample average of 16 percentage points. ${ }^{47}$ These results are fairly similar across purchase mortgages and refinancings and are also robust to controlling for loan characteristics.

To sum up, the results in this section indicate that heightened forbearance and nonpayment risk did have some chilling effects on mortgage credit supply outside the prime conforming market. Those affected include low-income FHA borrowers as well as highincome jumbo borrowers ineligible for government guarantees. ${ }^{48}$

\footnotetext{
${ }^{47}$ In Internet Appendix $\mathrm{G}$ we trace out the dynamics of the jumbo share by replacing the single pandemic dummy with a vector of time dummies. These coefficients show a sustained downward trend in the fraction of jumbo loans beginning in early 2020, which bottoms out in the third quarter.

${ }^{48}$ In Internet Appendix $\mathrm{H}$ we also study lending in the small non-qualified-mortgage ("non-QM") part of the jumbo market (the non-QM segment is studied in detail in DeFusco et al., 2019). We find non-QM lending drops in line with jumbo lending as a whole during the pandemic, but there is no obvious evidence of an amplification of the legal risk associated with non-QM loans.
} 


\section{VI.B Quantitative Easing}

The Fed rapidly increased the size of its MBS portfolio during the early months of the crisis, from $\$ 1.37$ trillion at the start of March 2020 to $\$ 1.90$ trillion by the start of July (source: New York Federal Reserve Bank). Since the Fed purchases only agency MBS (excluding jumbos), our evidence above on the jumbo market may in part reflect the beneficial effects of Fed QE on mortgage credit supply. Understanding the effects of QE during the pandemic is also of independent interest.

The earlier time-series evidence in Figure 2 suggests that the resumption of Fed QE in mid-March did reduce mortgage financing costs. OAS drops by about $40 \mathrm{bp}$ right after QE begins, and option cost declines due to a drop in interest rate volatility. These changes are almost exactly offset by a rise in the primary-secondary spread, however, leaving the mortgage-Treasury spread almost unchanged.

A different way to measure these effects that does not just rely on time-series variation is to study superconforming mortgages exceeding the national conforming limit, as we already did in Section VI.A.2. Superconforming mortgages are less likely to be purchased by the Fed because the Fed obtains agency MBS pools through the "to-be-announced" or TBA market, and pools comprising more than 10 percent of superconforming loans are not TBA eligible (Vickery and Wright, 2013; Huh and Kim, 2020). Matching eMBS loanlevel data to security-level data on the Fed's MBS holdings, we confirm that the probability of an agency mortgage ending up in a pool in the Fed's MBS portfolio does indeed drop sharply just above the national conforming limit, declining by about 40 percent.

Using this fact, panel B of Table 4 restricts our McDash sample just to high-cost counties and studies relative shifts in lending around both the national conforming loan limit (columns 1 through 3) and the higher local limit (columns 4 through 6). This allows us to disentangle the effects of Fed QE from credit guarantees. The results indicate that both QE and guarantees appear to have promoted credit supply-lending drops in relative terms just above both the national and local limits during the pandemic. The effects around the local limit (the upper bound to qualify for government guarantees) are quantitatively larger relative to the sample mean, however, suggesting that credit guarantees had a relatively larger effect in bolstering credit supply.

Figure A.20 in the Internet Appendix further explores the dynamics of these effects, 
finding that the loan volume effects around the national limit (which reflect only QE) are significant in the early stages of the pandemic, but they are less persistent than the effects at the local limit. This is consistent with our earlier interest rate estimates in Figure 10, which show that the superconforming-conforming spread is elevated only through June 2020, while the jumbo-conforming spread remains high throughout 2020.

We conclude that Fed QE lowered mortgage rates and expanded credit supply during the pandemic, but that the direct effects of QE may have faded after a few months. Our estimates do not reflect the full general-equilibrium effects of $\mathrm{QE}$, however, and thus should be interpreted accordingly.

\section{VI.C Summing Up}

Our results indicate that government-backed credit guarantees supported mortgage lending during the pandemic, evidenced by a relative increase in rates and decline in quantities in the jumbo market, which does not feature guarantees. Our analysis of the FHA market, however, also shows that public guarantees are not always sufficient to fully insulate lenders against default risk-we find evidence of a contraction in supply for high-risk FHA borrowers despite the presence of guarantees. Federal Reserve quantitative easing also supported credit supply, particularly in the early stages of the pandemic.

\section{Conclusion}

The mortgage market experienced a historic boom in 2020, with record origination volumes and lender profits. But while many borrowers benefited from record-low mortgage rates, the evidence presented in this paper suggests that intermediation frictions limited the pass-through of lower rates to households. This limited pass-through is only partially explained by the historical relationship between markups and mortgage demand. Several pieces of evidence indicate that operational frictions reduced the elasticity of mortgage supply; in other words, hiring new workers and expanding capacity was more difficult than usual, keeping lender markups high. At the same time, there was a shift in the underwriting of complex loans toward more elastic "fintech" lenders.

As in the 2008 financial crisis, government credit guarantees have played an impor- 
tant role in stabilizing credit supply, reflected in a larger increase in mortgage interest rate spreads in the jumbo segment of the market, where such guarantees are absent. However, our results also highlight the fact that such guarantees have not fully insulated lenders from risk, and that this residual exposure has been priced into mortgage interest rates at least for some borrowers. Our results are suggestive of some surprising "barbell" distributional effects of the pandemic, with low-income FHA borrowers and high-income jumbo borrowers experiencing a decline in credit availability relative to middle-class borrowers.

Our results show that during the last three quarters of 2020, intermediaries collected 4 to 5 percent of a mortgage's balance for the service of linking borrowers with savers, or about $\$ 160$ billion in total. One surprising question is whether for rate-and-term refinances, it makes sense for intermediaries to collect anything. For an individual lender making a loan to a new borrower, careful underwriting makes sense, as the lender is taking on a new risk. But from the standpoint of the economy as a whole, a rate-and-term refinance uniformly lowers the likelihood of default, even if no new underwriting is done.

The costs of socially unnecessary underwriting cascade across the economy. For some borrowers, the high price of intermediation makes refinancing uneconomic. For borrowers who do refinance, the reduction in rates is smaller. Binding capacity constraints during lending booms mean that rate-and-term refinances starve resources from the more socially useful task of underwriting purchase loans and cash-out refinances. In 2020, operational frictions related to the pandemic only amplified these capacity constraints. Our findings, therefore, reinforce arguments for both streamlined refinances and automatically refinancing mortgage products. Much like during the financial crisis, such products would have substantially strengthened the transmission of low interest rates to households during the pandemic. 


\section{References}

Agarwal, S., S. Chomsisengphet, H. Kiefer, L. C. Kiefer, and P. C. Medina (2021): "Inequality During the COVID-19 Pandemic: The Case of Savings from Mortgage Refinancing," Working Paper.

Amromin, G., N. Bhutta, And B. J. Keys (2020): “Refinancing, Monetary Policy, and the Credit Cycle," Annual Review of Financial Economics, 12, 67-93.

AN, X., L. Cordell, L. GenG, AND K. LeE (2021): "Inequality in the Time of COVID-19: Evidence from Mortgage Delinquency and Forbearance," Working Paper 21-09, Federal Reserve Bank of Philadelphia.

Berger, D. W., K. Milbradt, F. Tourre, and J. Vavra (2020): “Mortgage Prepayment and Path-Dependent Effects of Monetary Policy," Working Paper 25157, National Bureau of Economic Research.

Berry, K. And A. Kline (2020): “Virus Scare Creates Perfect Storm for Mortgage Lenders," American Banker, March 19.

Bhutta, N., A. Fuster, And A. Hizmo (2021): “Paying Too Much? Borrower Sophistication and Overpayment in the US Mortgage Market," Discussion Paper 14924, CEPR.

Black Knight Financial Services (2020): “Mortgage Monitor: October 2020 Report,” Tech. rep.

Boyarchenko, N., A. Fuster, And D. O. Lucca (2019): “Understanding Mortgage Spreads," Review of Financial Studies, 32, 3799-3850.

Bracke, P., K. Croxson, D. Fakhri, P. Surico, And T. Valletti (2020): “Mortgage Market Disruptions," Occasional Paper 57, Financial Conduct Authority.

BuchaK, G., G. MAtvos, T. Piskorski, And A. Seru (2018): “Fintech, Regulatory Arbitrage, and the Rise of Shadow Banks," Journal of Financial Economics, 130, $453-483$.

Calem, P., F. Covas, AND J. WU (2013): “The Impact of the 2007 Liquidity Shock on Bank Jumbo Mortgage Lending," Journal of Money, Credit and Banking, 45, 59-91.

Campbell, J. Y., N. Clara, AND J. F. COCco (2020): "Structuring Mortgages for Macroeconomic Stability," Journal of Finance, forthcoming. 
CAPPONI, A., R. JiA, AND D. A. RiOs (2021): “The Effects of Mortgage Forbearance on Refinancing: Evidence from the COVID-19 Period," Covid Economics, 68, 1-46.

Cherry, S. F., E. X. Jiang, G. Matvos, T. Piskorski, And A. Seru (2021): “Government and Private Household Debt Relief during COVID-19," Working Paper 28357, National Bureau of Economic Research.

Davidson, A. AND A. Levin (2014): Mortgage Valuation Models: Embedded Options, Risk, and Uncertainty, Oxford University Press.

DeFusco, A. A., S. Johnson, And J. Mondragon (2019): “Regulating Household Leverage," Review of Economic Studies, 87, 914-958.

Di Maggio, M., A. Kermani, B. J. Keys, T. Piskorski, R. Ramcharan, A. Seru, AND V. YAO (2017): “Interest Rate Pass-Through: Mortgage Rates, Household Consumption, and Voluntary Deleveraging," American Economic Review, 107, 3550-88.

Di Maggio, M., A. Kermani, and C. J. Palmer (2020): “How Quantitative Easing Works: Evidence on the Refinancing Channel," Review of Economic Studies, 87, 14981528.

Eberly, J. And A. Krishnamurthy (2014): “Efficient Credit Policies in a Housing Debt Crisis," Brookings Papers on Economic Activity, 45, 73-136.

EISEN, B. (2020): “Wells Fargo Curtails Jumbo Loans Amid Market Turmoil," Wall Street Journal, April 4.

EREL, I. AND J. Liebersohn (2020): “Does FinTech Substitute for Banks? Evidence from the Paycheck Protection Program," Working Paper 27659, National Bureau of Economic Research.

FABOZZI, F. J., ed. (2016): The Handbook of Mortgage-Backed Securities, Oxford University Press, 7 th ed.

Federal Housing Finance Agency (2020): “FHFA Addresses Servicer Liquidity Concerns, Announces Four Month Advance Obligation Limit for Loans in Forbearance," Press release, April 21. 
Fuster, A., L. Goodman, D. Lucca, L. Madar, L. Molloy, And P. Willen (2013): “The Rising Gap between Primary and Secondary Mortgage Rates," Federal Reserve Bank of New York Economic Policy Review, 19, 17-39.

Fuster, A., S. H. Lo, AND P. S. Willen (2017): “The Time-Varying Price of Financial Intermediation in the Mortgage Market," Staff Report 805, Federal Reserve Bank of New York.

Fuster, A., M. Plosser, P. Schnabl, And J. Vickery (2019): “The Role of Technology in Mortgage Lending," Review of Financial Studies, 32, 1854-1899.

Fuster, A. AND P. S. Willen (2017): “Payment Size, Negative Equity, and Mortgage Default," American Economic Journal: Economic Policy, 9, 167-91.

Guren, A. M., A. Krishnamurthy, And T. J. McQuade (2020): “Mortgage Design in an Equilibrium Model of the Housing Market," Journal of Finance, forthcoming.

Horvath, A., B. KAY, AND C. WIX (2020): “The COVID-19 Shock and Consumer Credit: Evidence from Credit Card Data," SSRN Electronic Journal.

Hughes, C. (2020): "Coronavirus Complicates Home Buying and Mortgage Refinancing," New York Times, March 23.

HUH, Y. AND Y. S. KIM (2020): “The Real Effects of Secondary Market Trading Structure: Evidence from the Mortgage Market," Working Paper, Federal Reserve Board.

IVERSON, B., J. WANG, J. YANG, AND R. KLuENDER (2020): “Bankruptcy and the COVID19 Crisis," Working Paper.

IVEY, B. (2020): “Lender/Servicer Retention Rates Fall Even as Refis Rise," Inside Mortgage Finance, 2020:35, September 11.

JiAng, E., G. Matvos, T. Piskorski, AND A. Seru (2020): “Banking without Deposits: Evidence from Shadow Bank Call Reports," Working Paper 26903, National Bureau of Economic Research.

KeYs, B. J., D. G. POPE, AND J. C. POPE (2016): “Failure to Refinance," Journal of Financial Economics, 122, 482-499. 
Kim, Y. S., S. M. Laufer, K. Pence, R. Stanton, And N. Wallace (2018): “Liquidity Crises in the Mortgage Market," Brookings Papers on Economic Activity, 49, 347-428.

KleimanN, J. (2020): “On Earnings Debut, Rocket Reveals Plans to Dominate the U.S. Mortgage Market," HousingWire, September 3.

Kwan, A., C. Lin, V. Pursiainen, And M. TAi (2021): “Stress Testing Banks' Digital Capabilities: Evidence From the COVID-19 Pandemic," Working Paper, University of Hong Kong and University of St. Gallen.

Lambie-Hanson, L. (2020): "Residential Mortgage Refinancing During the COVID-19 Pandemic," Special report, Federal Reserve Bank of Philadelphia.

McManus, D. AND E. YANNOPOUlOS (2021): “COVID-19 Mortgage Forbearances: Drivers and Payment Behavior," Journal of Structured Finance, 27.

Mortgage BANKers Association (2019): “Implementation of MBO Transitional Authority," Issue brief.

— (2021): “Mortgage Credit Availability Decreased in December,” Data Release.

Scharfstein, D. And A. Sunderam (2016): "Market Power in Mortgage Lending and the Transmission of Monetary Policy," Working Paper, Harvard University.

Sharpe, S. A. AND S. M. Sherlund (2016): “Crowding Out Effects of Refinancing on New Purchase Mortgages," Review of Industrial Organization, 48, 209-239.

Tozer, T. (2019): “A Primer and Perspective on Ginnie Mae," Milken Institute Discussion Paper.

Urban Institute (2021): “Housing Finance at a Glance: A Monthly Chartbook," February.

VICKERY, J. AND J. WRIGHT (2013): “TBA Trading and Liquidity in the Agency MBS Market," Federal Reserve Bank of New York Economic Policy Review, 19, 1-18.

WOLINSKY, A. (1986): “True Monopolistic Competition as a Result of Imperfect Information," Quarterly Journal of Economics, 101, 493-511. 
Figure 2: Accounting for the Rise in the Mortgage-Treasury Spread During Two Crises

A. COVID-19 Pandemic (2020)

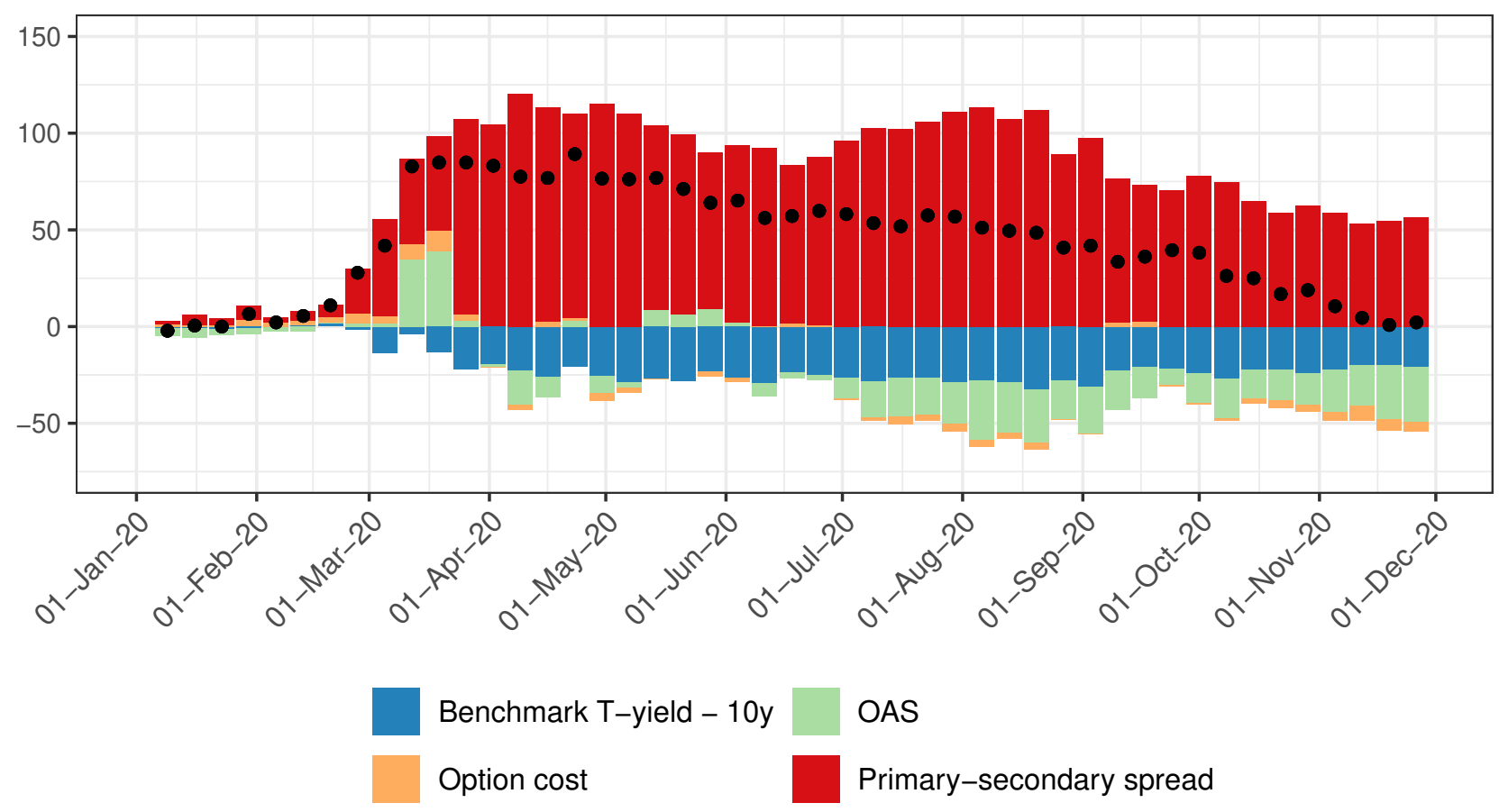

B. Global Financial Crisis (2007-2009)

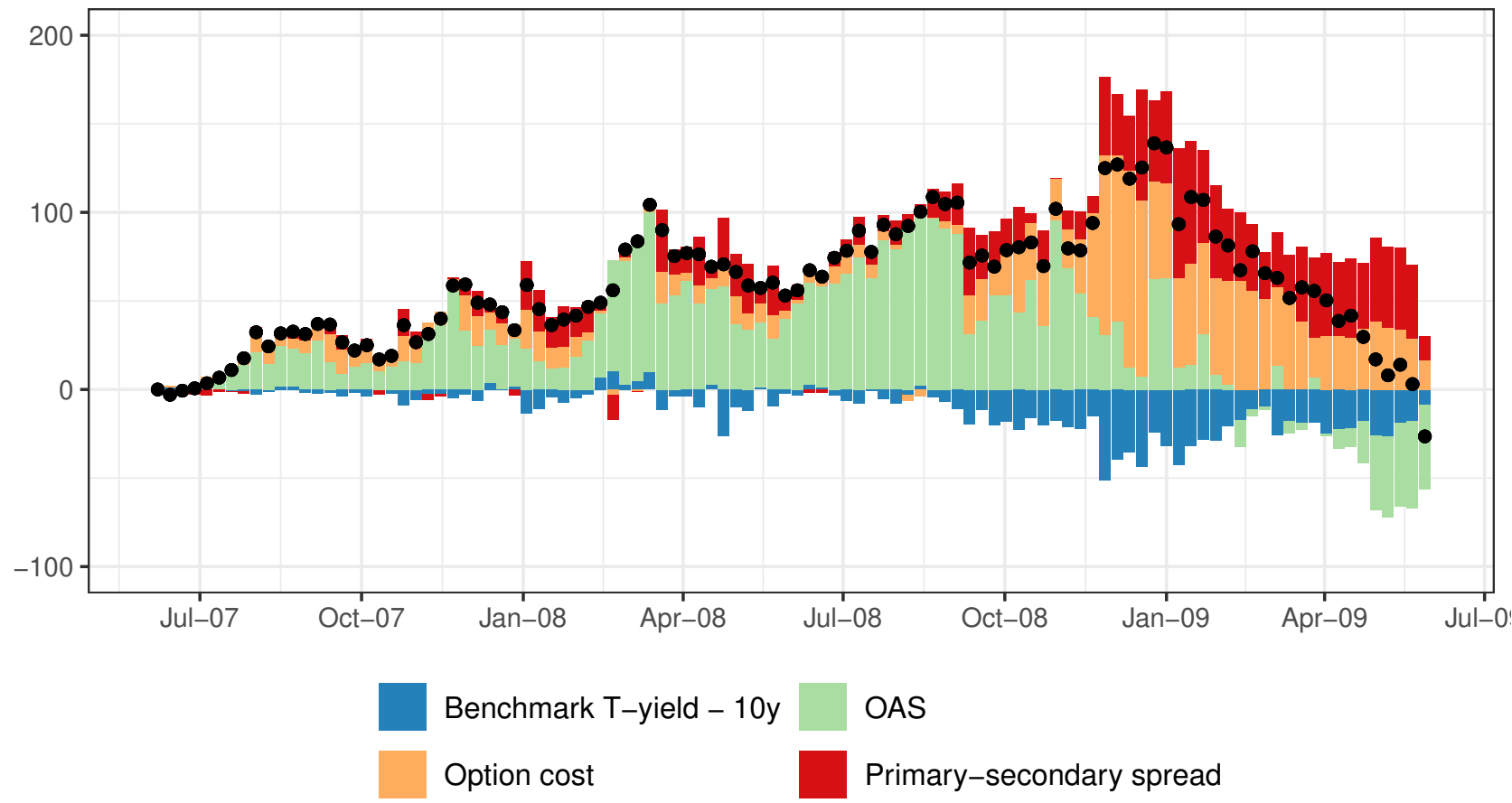

Black dots show the change in spread between headline mortgage rate (from PMMS) and 10-year Treasury yields relative to the beginning of each episode, in basis points. Decomposition based on the methodology described in Section III.A. Data sources: Freddie Mac PMMS, Optimal Blue, J.P. Morgan Markets. 


\section{Figure 3: Intermediation Markups in the Conforming Market}

\section{A. Primary-Secondary Spread}

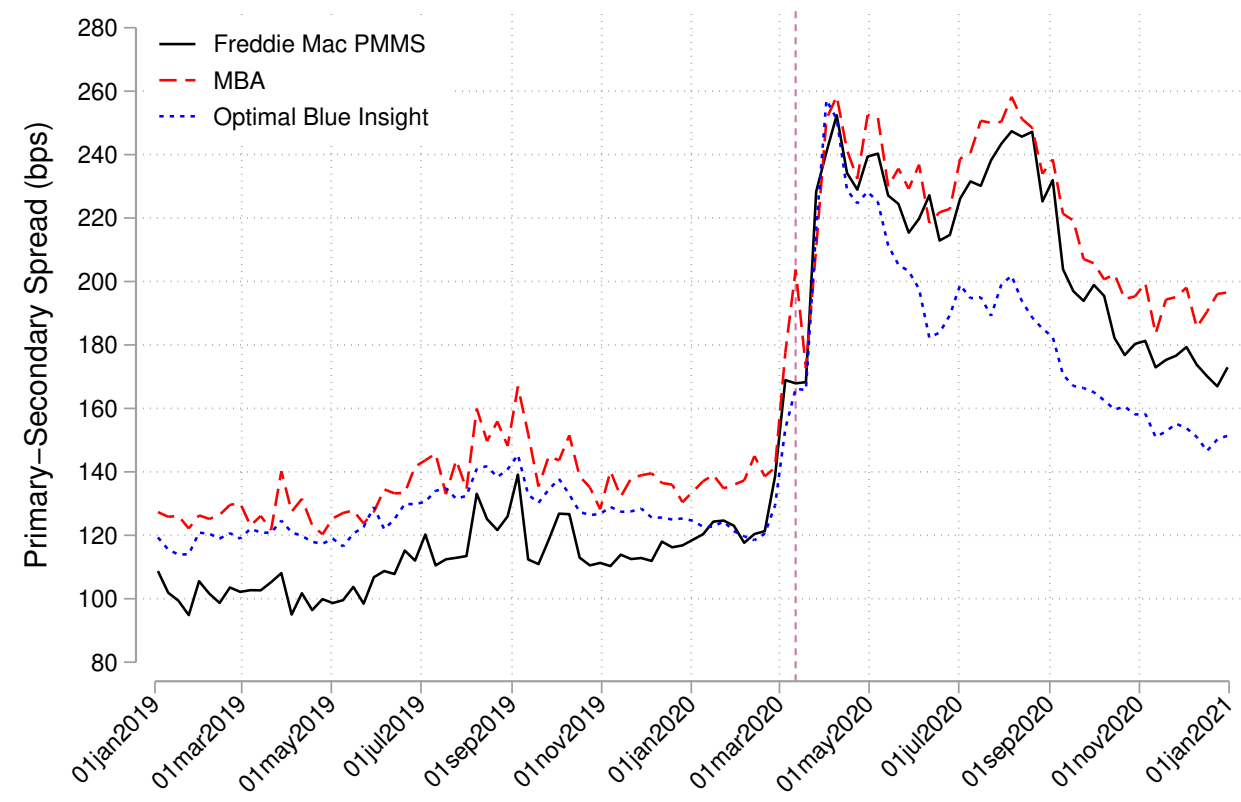

\section{B. Gain-On-Sale}

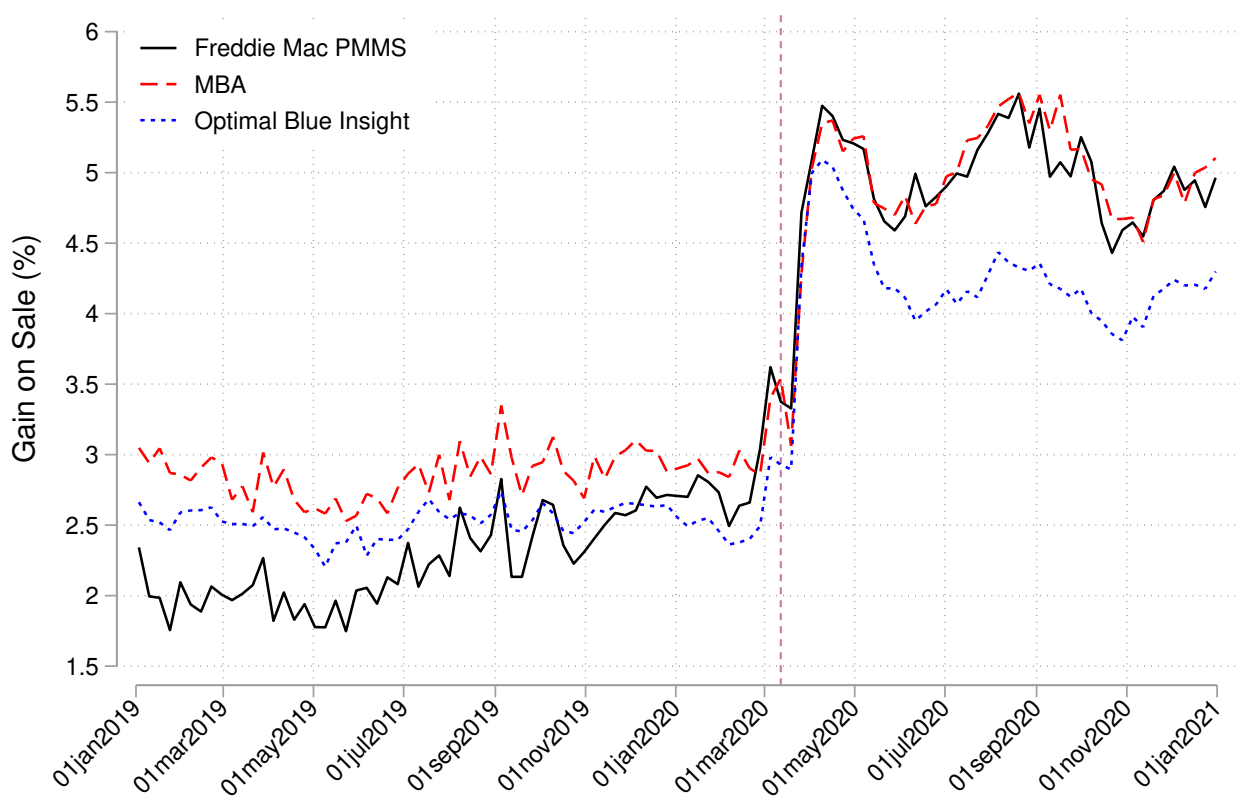

Primary-secondary spread (panel A) and gain-on-sale (panel B) measured based on the methodologies described in Sections III.A.1 and III.C, respectively. Data sources: Freddie Mac PMMS, Optimal Blue, J.P. Morgan Markets, MBA (via Haver Analytics).

Notes: Vertical line represents the declaration of a national state of emergency in March 13th, 2020. 
Figure 4: Lenders' Reported Net Production Income

\section{A. In basis points}

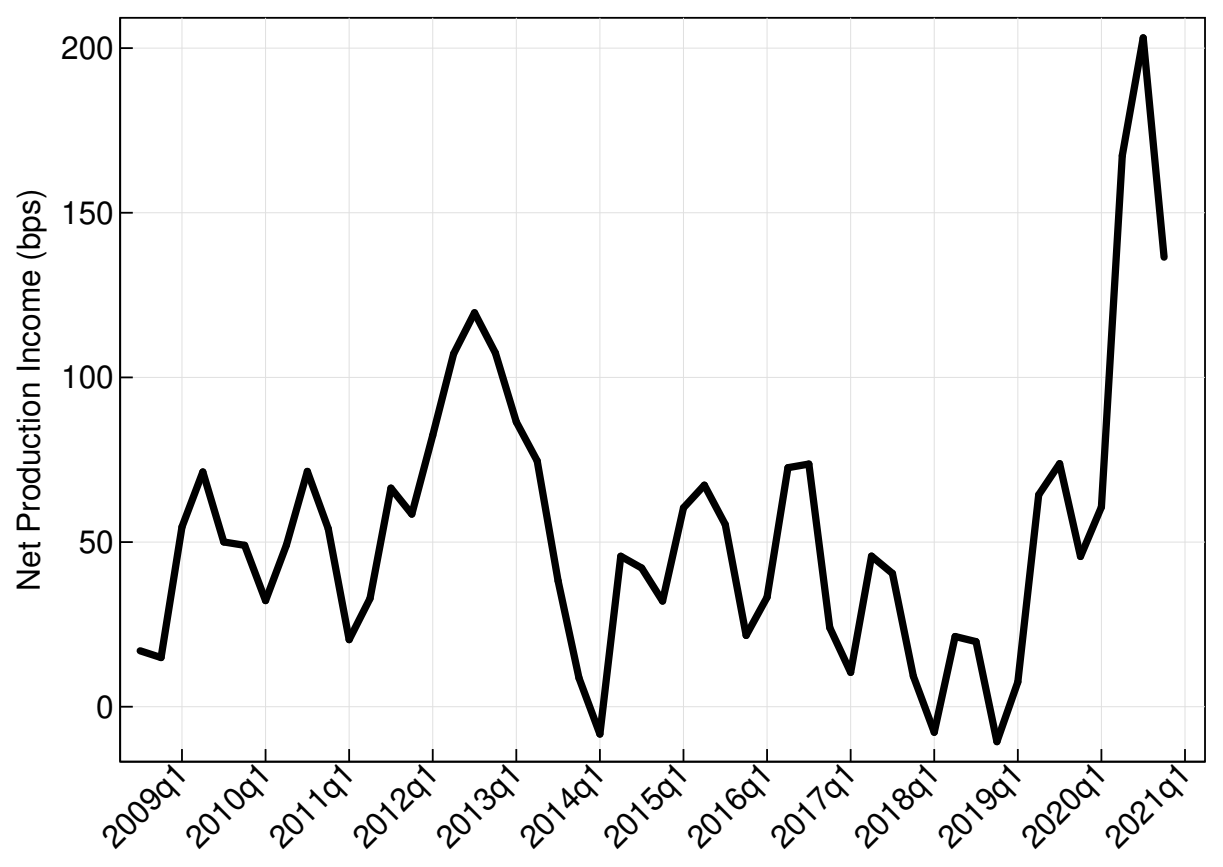

B. Multiplied by average originated loan volume

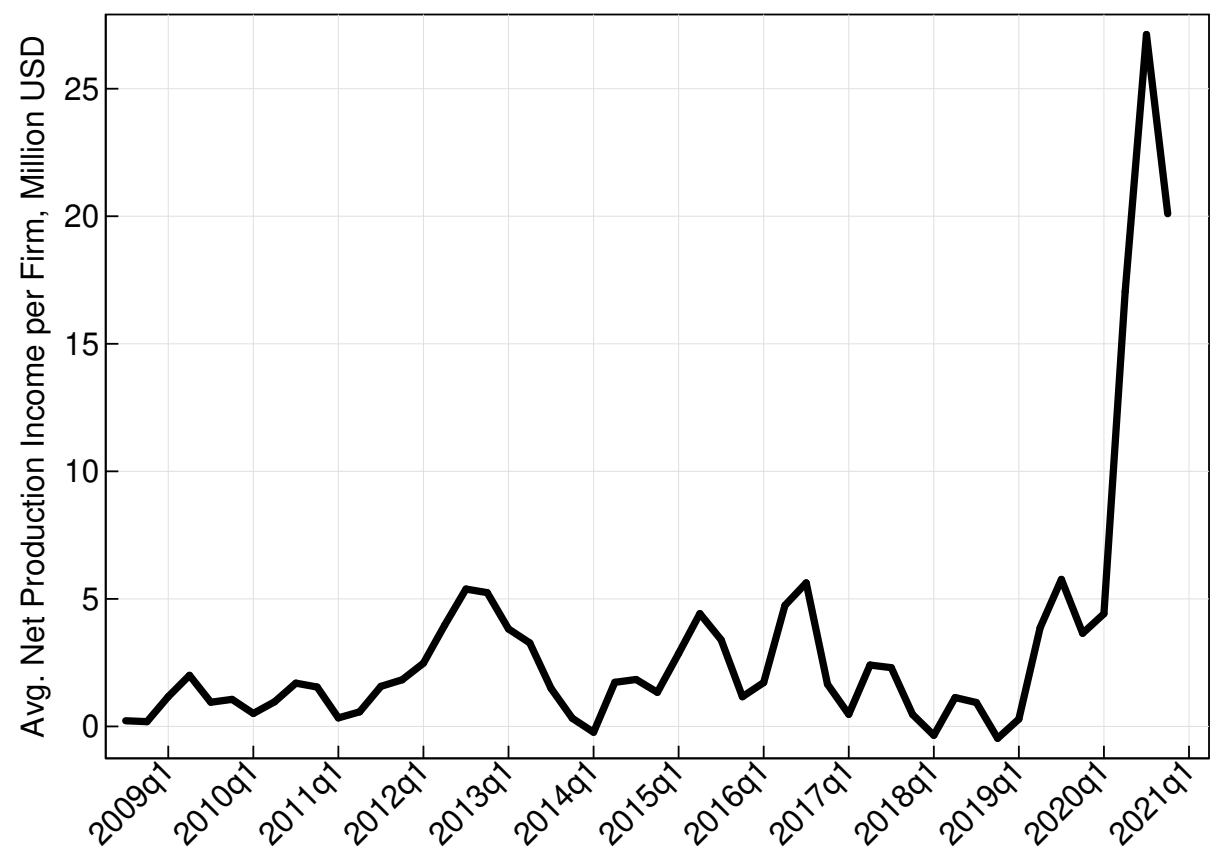

Data source: Mortgage Bankers Association Quarterly Performance Report (QPR). Sample period: 2008:Q32020:Q4. Series in panel A is "Total Net Production Income, Basis Points, Simple Average" from Table B2 of the QPR. For panel B, this series is multiplied by "Avg. Total Loans Originated (\$000s)" from the same table. 
Figure 5: Intermediation Markups and the Demand for Refinancing

A. Prim.-Sec. Spread vs. Proxy for Refi Incentives

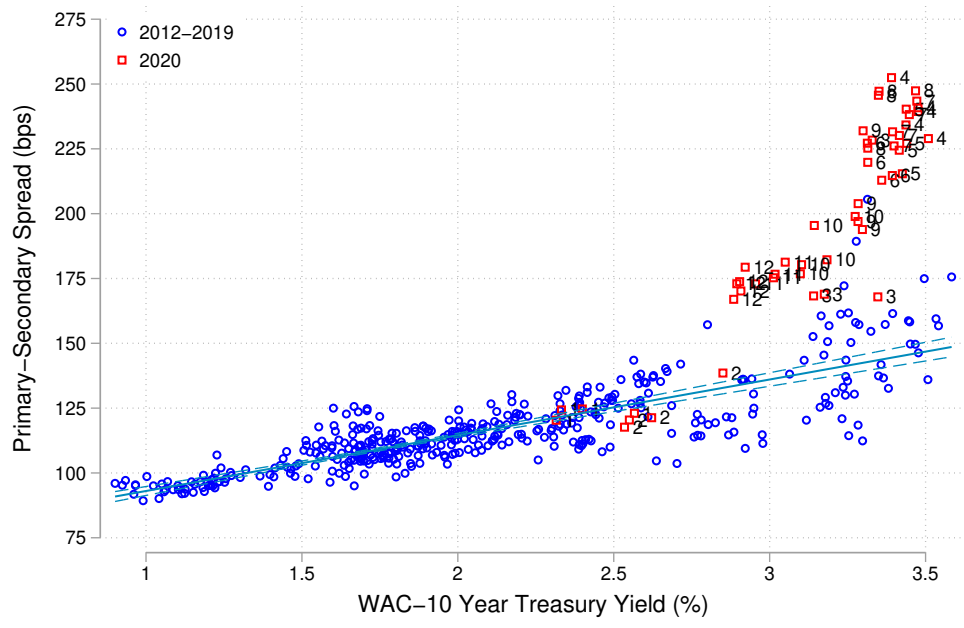

\section{Gain-on-Sale vs. Proxy for Refi Incentives}

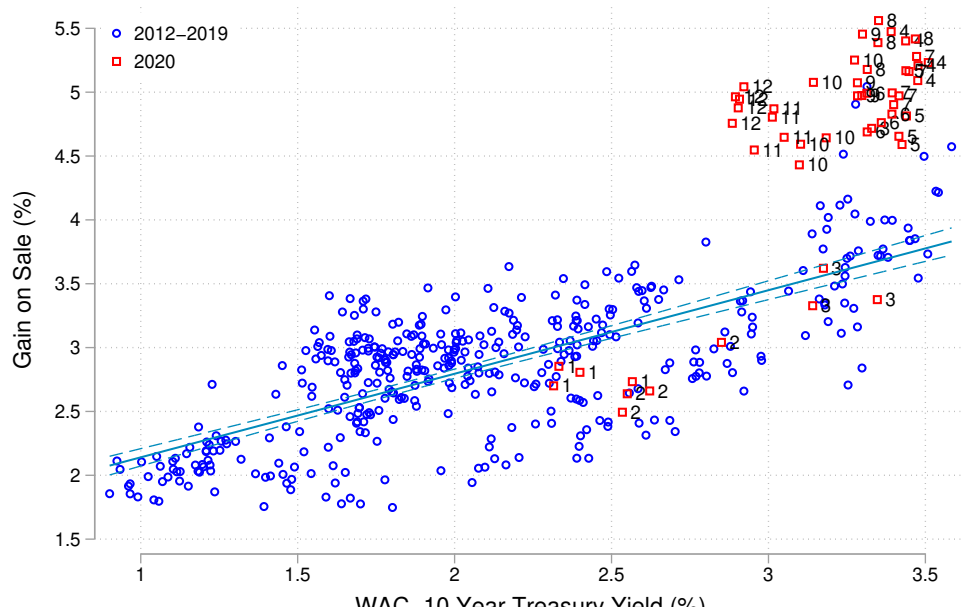

B. Prim.-Sec. Spread vs. Application Volume

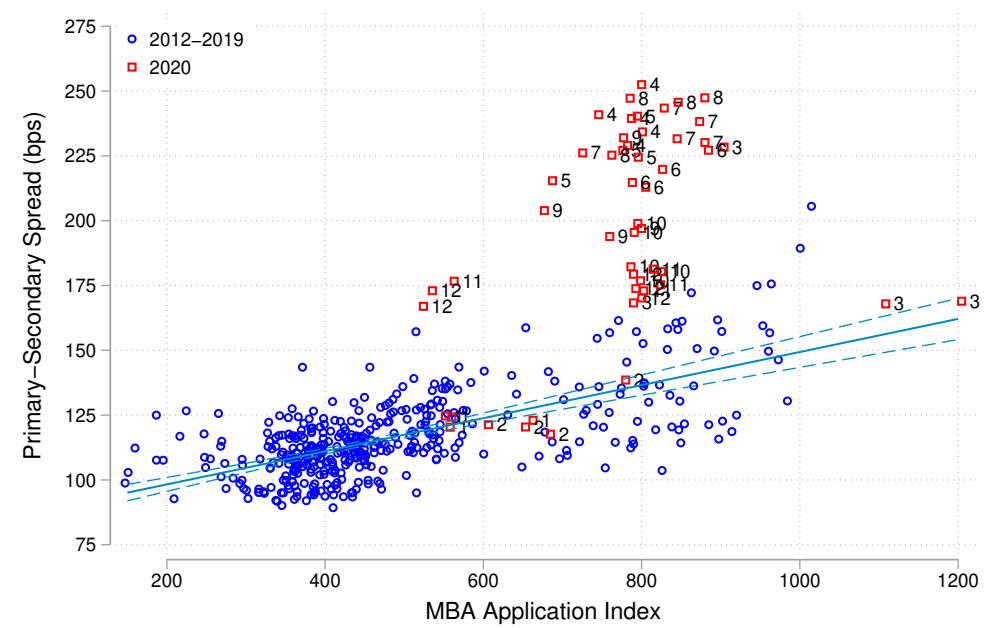

D. Gain-on-Sale vs. vs. Application Volume

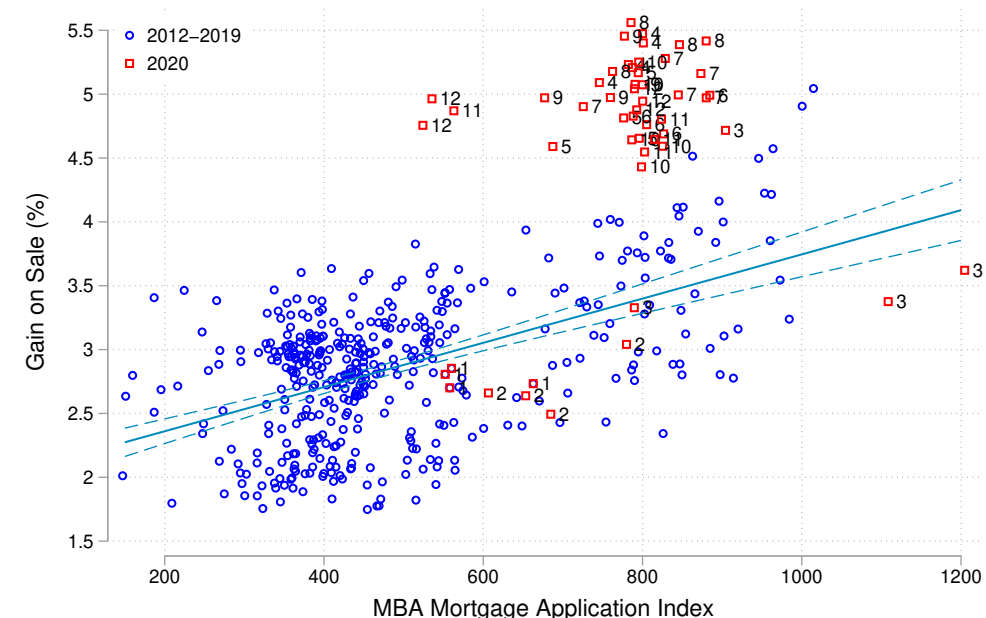

Notes: numbers next to red squares denote the calendar month in 2020. The trend line and the $90 \%$ confidence intervals are estimates using data 2012-2019. Spreads and gain on sale computed based on the methodology described in Section III.C. Data sources: Freddie Mac PMMS; J.P. Morgan Markets; SitusAMC; Mortgage Bankers Association (via Haver Analytics). 


\section{Figure 6: Mortgage Loan Officer Job Postings and Employment Growth}

\section{A. Mortgage Loan Officer Postings and Employment}

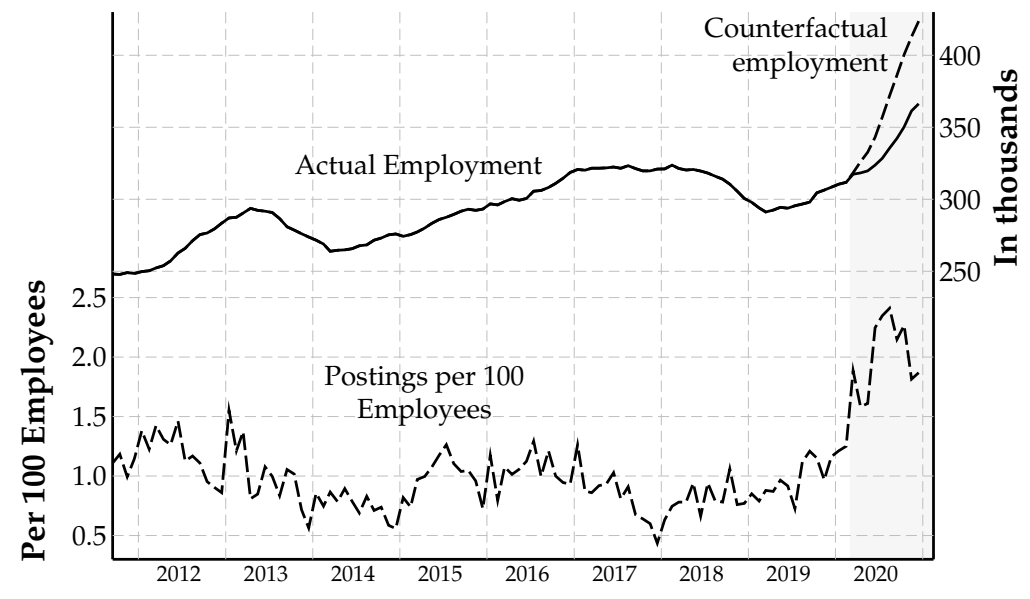

\section{B. Predicted versus Actual Employment Growth}

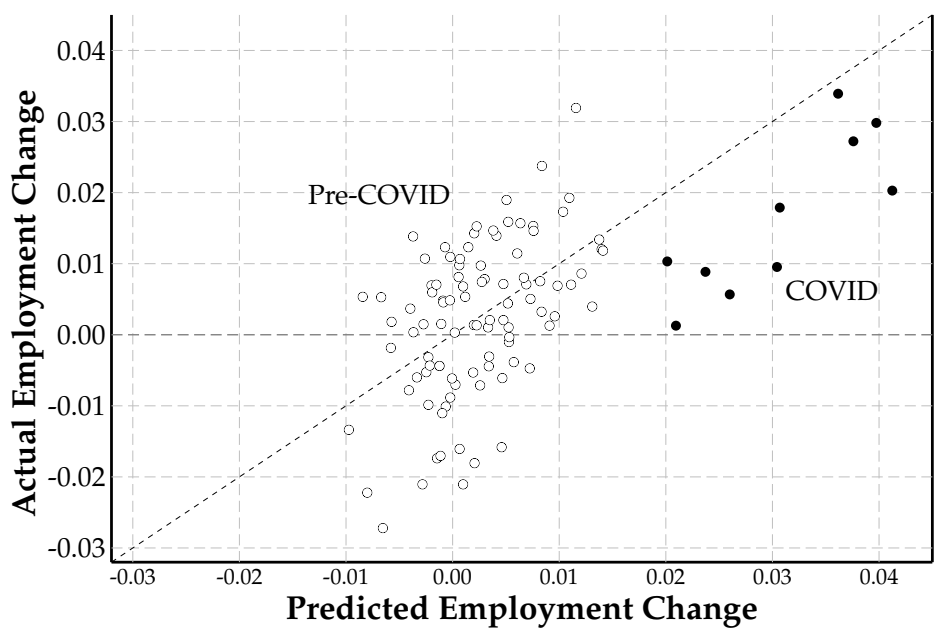

Panel A shows mortgage employment and postings per employee from the BLS Establishment Survey and Burning Glass Technologies. Panel B compares predicted and actual values from the regression

$$
\log M L O_{t+1}-\log M L O_{t}=\alpha+\beta_{1} p_{t}+\beta_{2} p_{t-1}+\beta_{2} p_{t-2}+\varepsilon_{t}
$$

where $M L O_{t}$ and $p_{t}$ correspond to mortgage employment and postings per employee in Panel A. Baseline regression is run on data from 3/2012 to 2/2020. Dots labeled "COVID" are out-of-sample predictions for 3/2020 to 12/2020. Counterfactual employment in Panel A uses the predicted growth rates from the regression to compute employment in the COVID period. 


\section{Figure 7: Credit Supply in the Conforming Market}

A. Offer rate spread: FICO 680 vs 750

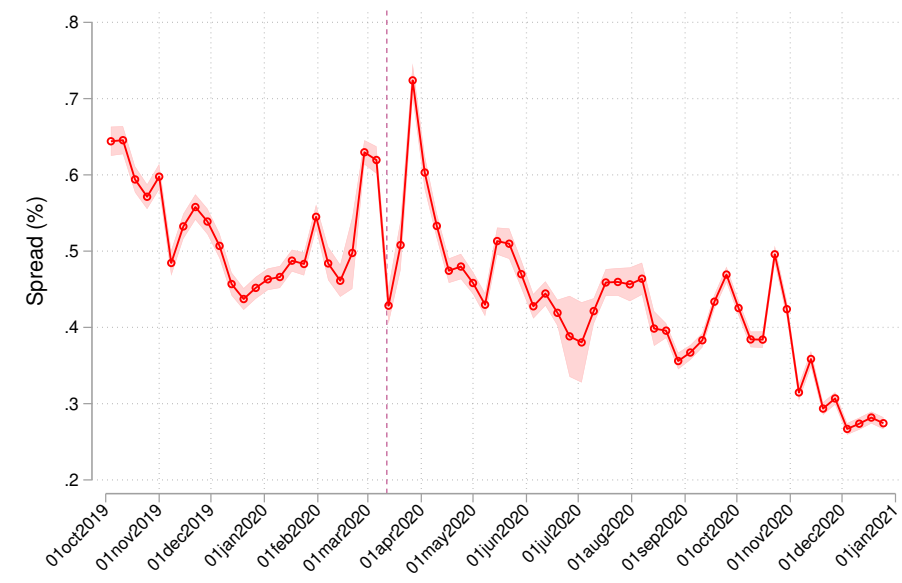

$\stackrel{t}{N}$
B. Locks rate spread: FICO 680 vs $740+$

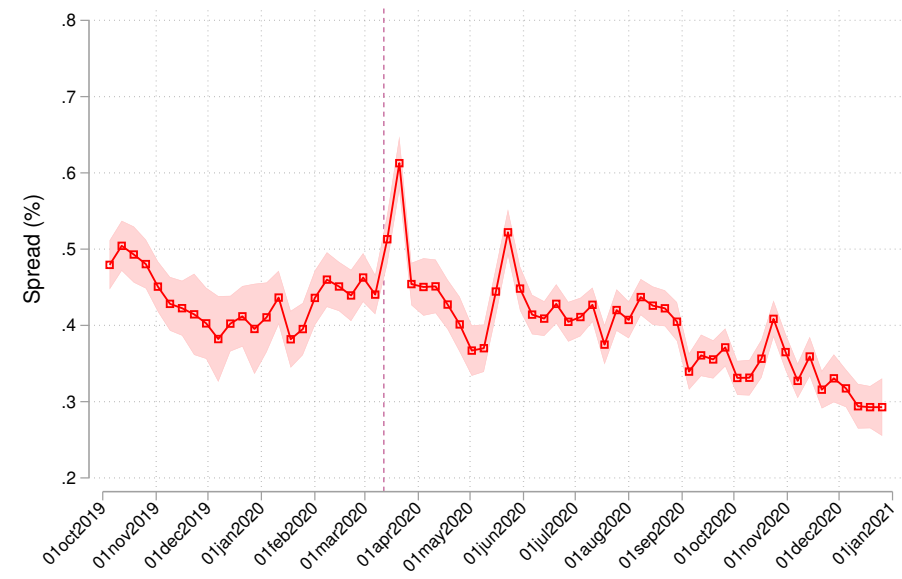

D. Distribution of rate locks by credit score

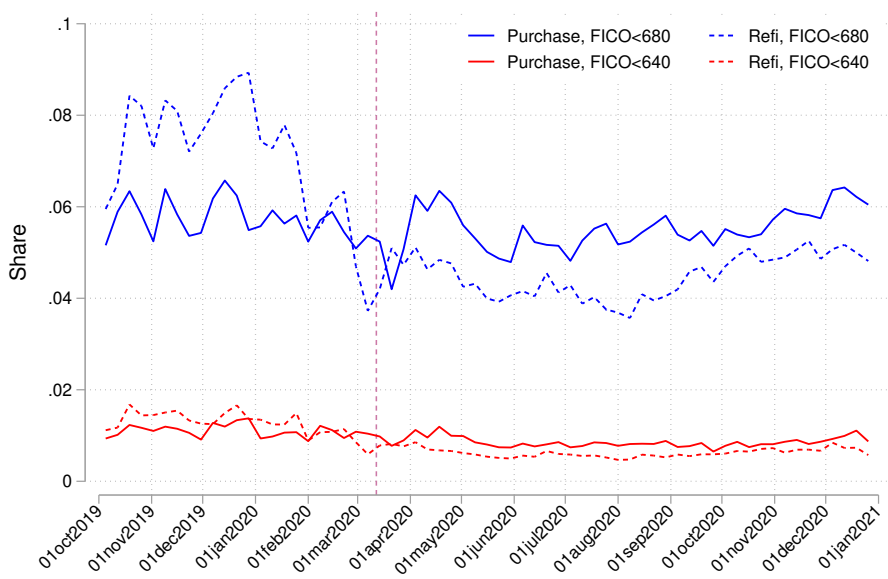

Notes: Measures of credit supply computed using the methodology described in Section V.A. Vertical line represents the declaration of a national state of emergency in March 13th, 2020. Data source: Optimal Blue 
Figure 8: Web Searches for Mortgage Refinancing

A. Google trends search index for refinance related terms

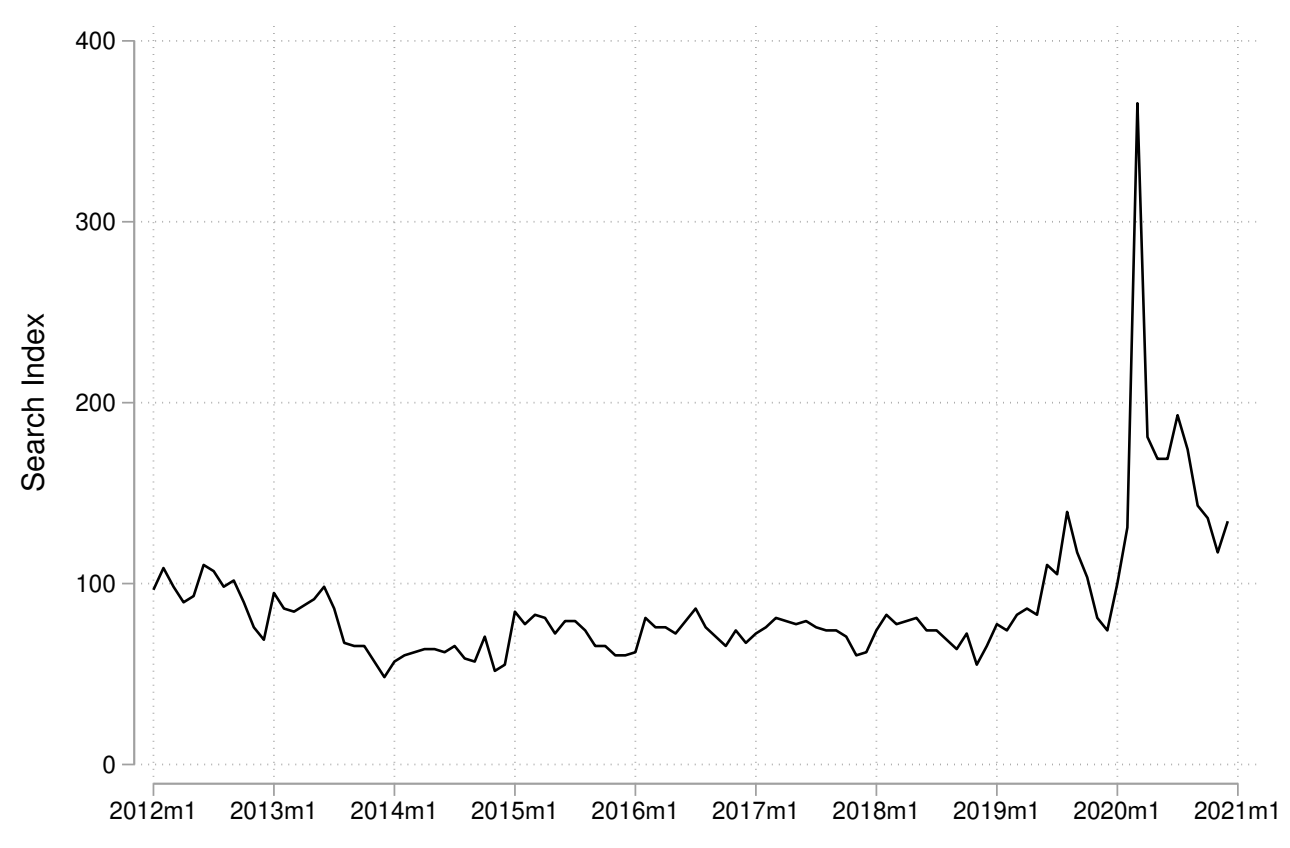

B. Google searches vs. the refinance incentive

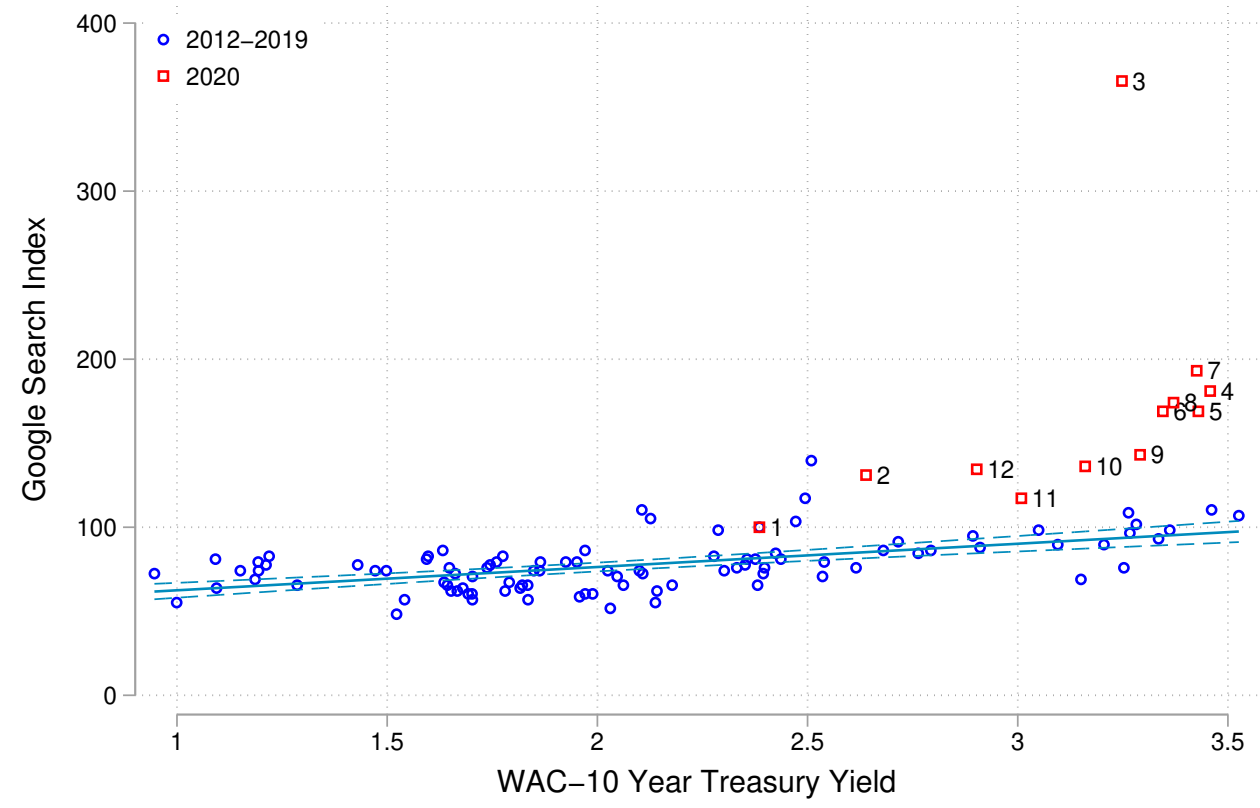

Notes: The Google search index is constructed by averaging the searches for the following terms: mortgage rate, mortgage refinance, mortgage lender, refinance cost, mortgage cost. Data source: Google Trends. 
Figure 9: Credit Supply in the FHA Market

A. Offer rate spread: FICO 640 vs 680

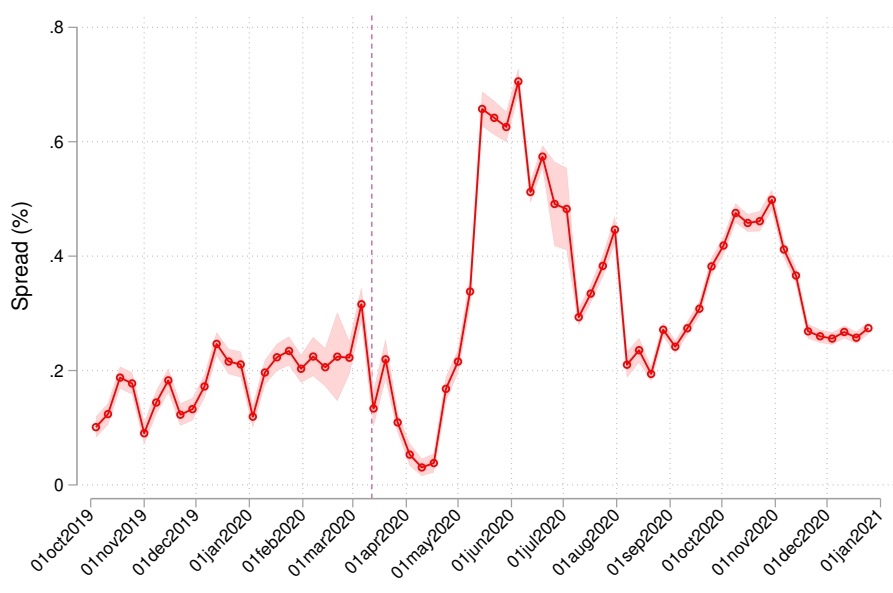

$\$$
B. Rate lock spread: FICO 640 vs 680

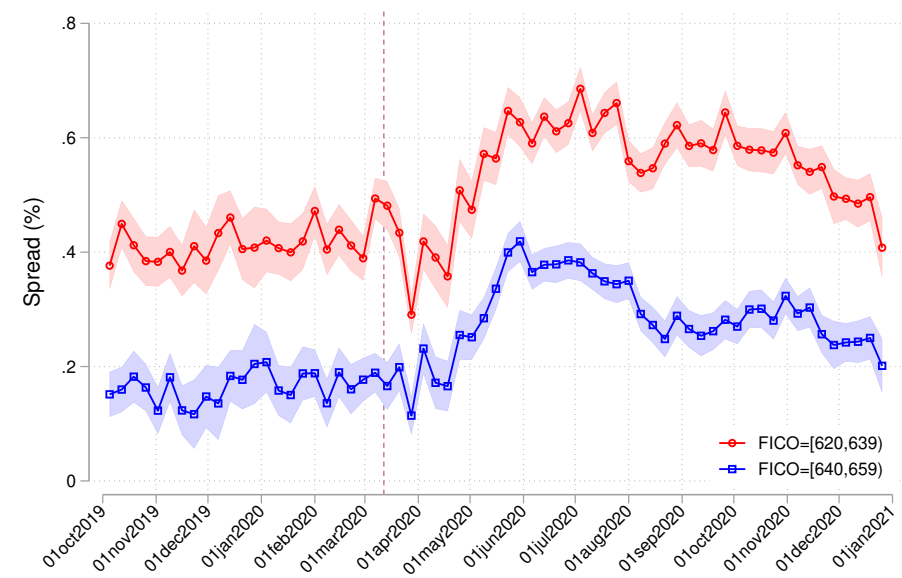

\section{Number of lenders posting offers}

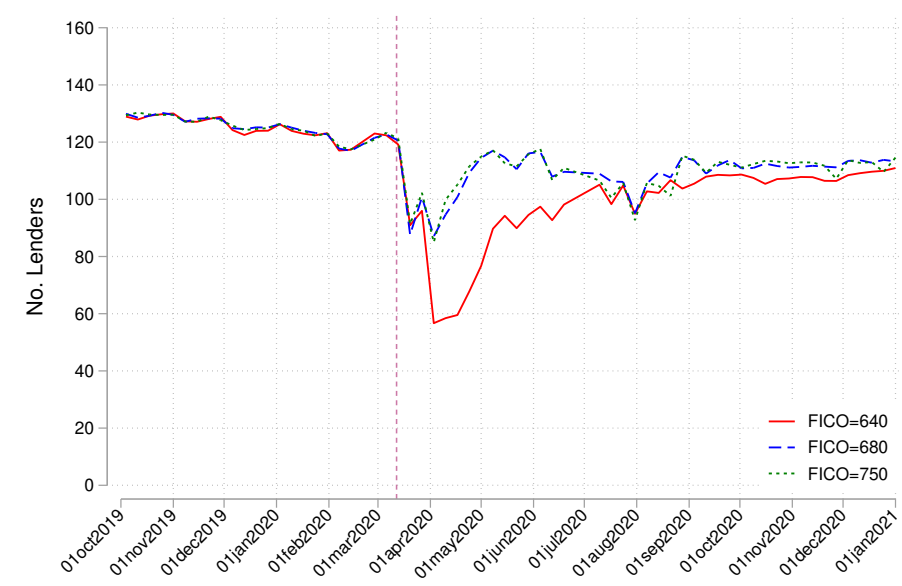

\section{Distribution of rate locks by credit score}

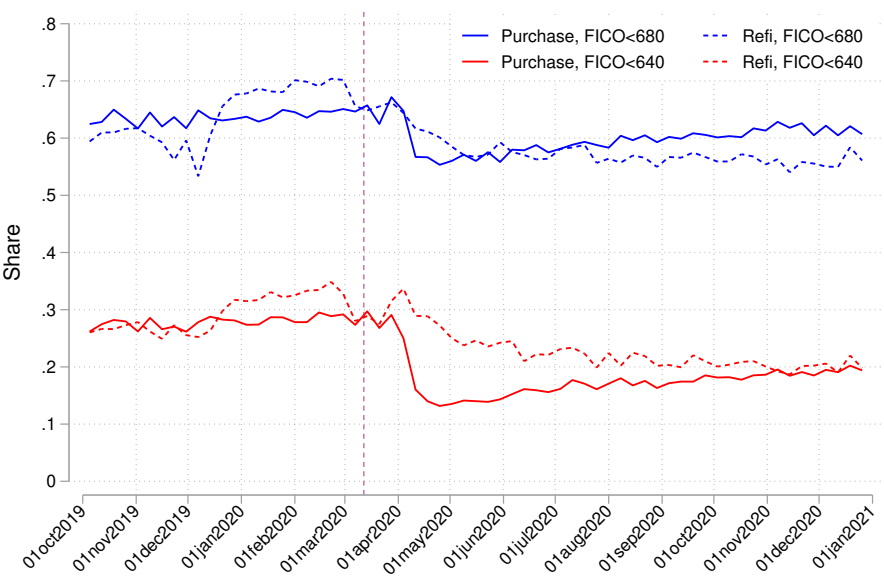

Notes: Measures of credit supply computed using the methodology described in Section V.A. Vertical line represents the declaration of a national state of emergency in March 13th, 2020. Data source: Optimal Blue 
Figure 10: Credit Supply in the Jumbo Market

A. Offer rate jumbo-conforming spread

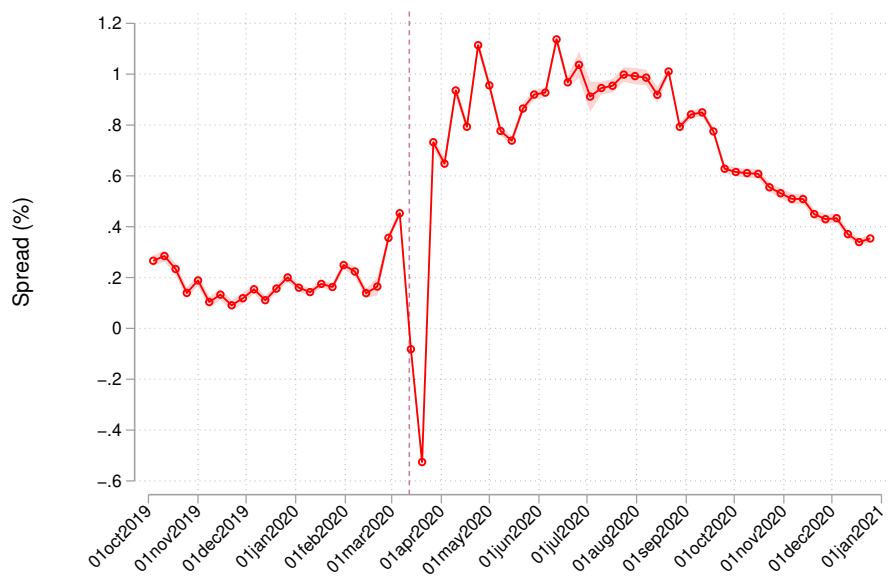

B. Rate lock spreads

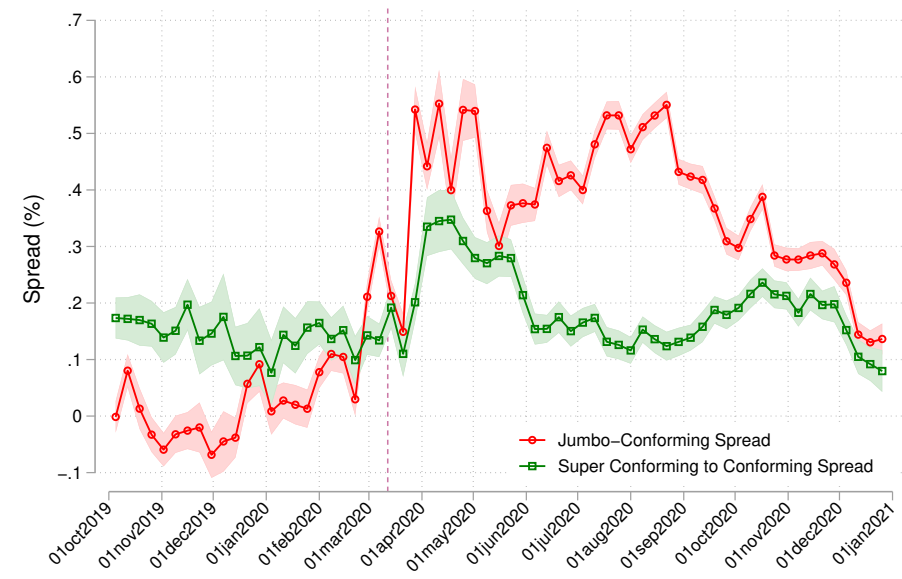

c

\section{Number of lenders posting offers}

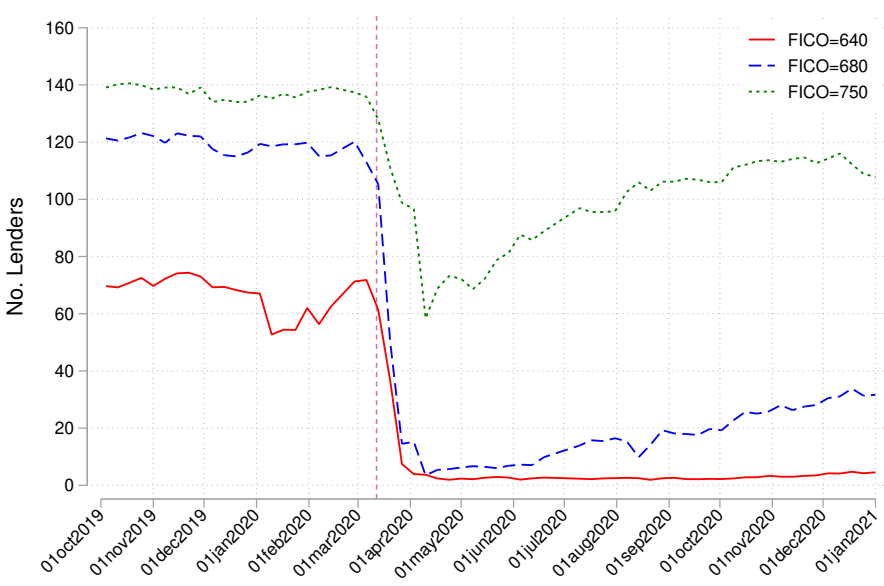

\section{Share of jumbo rate locks}

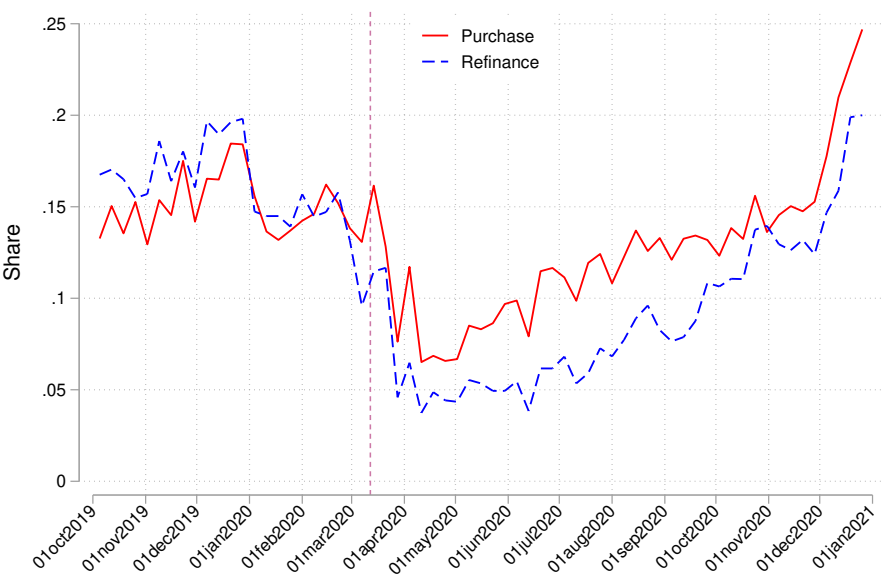

Notes: Measures of credit supply computed using the methodology described in Section V.A. Vertical line represents the declaration of a national state of emergency in March 13th, 2020. Data source: Optimal Blue 


\section{Table 1: Intermediation Markups and Mortgage Demand}

\begin{tabular}{|c|c|c|c|c|}
\hline & \multicolumn{2}{|c|}{$\begin{array}{l}\text { Primary-Secondary } \\
\text { Spread (bp) }\end{array}$} & \multicolumn{2}{|c|}{$\begin{array}{l}\text { Gain-on-Sale } \\
\text { (\$ per } \$ 100 \text { face value) }\end{array}$} \\
\hline Refi incentive (WAC - 10 Year Treasury) & $\begin{array}{c}21.71^{* * *} \\
(1.996)\end{array}$ & & $\begin{array}{l}0.655^{* * *} \\
(0.0636)\end{array}$ & \\
\hline MBA Applications Index & & $\begin{array}{c}0.0718^{* * *} \\
(0.0109)\end{array}$ & & $\begin{array}{l}0.00192^{* * *} \\
(0.000369)\end{array}$ \\
\hline March - May dummy & $\begin{array}{c}76.81^{* * *} \\
(10.45)\end{array}$ & $\begin{array}{c}82.58^{* * *} \\
(13.20)\end{array}$ & $\begin{array}{c}1.053^{* * *} \\
(0.270)\end{array}$ & $\begin{array}{c}1.300^{* * *} \\
(0.353)\end{array}$ \\
\hline June - August dummy & $\begin{array}{c}85.77^{* * *} \\
(5.268)\end{array}$ & $\begin{array}{c}90.42^{* * *} \\
(5.642)\end{array}$ & $\begin{array}{c}1.383^{* * *} \\
(0.154)\end{array}$ & $\begin{array}{c}1.598^{* * *} \\
(0.178)\end{array}$ \\
\hline September - October dummy & $\begin{array}{c}52.19^{* * *} \\
(7.214)\end{array}$ & $\begin{array}{c}55.34^{* * *} \\
(8.218)\end{array}$ & $\begin{array}{c}1.285^{* * *} \\
(0.189)\end{array}$ & $\begin{array}{c}1.451^{* * *} \\
(0.223)\end{array}$ \\
\hline November - December dummy & $\begin{array}{c}37.67^{* * *} \\
(3.042)\end{array}$ & $\begin{array}{c}33.81^{* * *} \\
(4.679)\end{array}$ & $\begin{array}{c}1.317^{* * *} \\
(0.114)\end{array}$ & $\begin{array}{c}1.285^{* * *} \\
(0.165)\end{array}$ \\
\hline Constant & $\begin{array}{c}70.88^{* * *} \\
(4.621)\end{array}$ & $\begin{array}{c}87.98^{* * *} \\
(5.368)\end{array}$ & $\begin{array}{c}1.484^{* * *} \\
(0.188)\end{array}$ & $\begin{array}{c}2.100^{* * *} \\
(0.216)\end{array}$ \\
\hline $\mathrm{N}$ & 466 & 466 & 466 & 466 \\
\hline Mean Y & 125.28 & 125.28 & 3.04 & 3.04 \\
\hline $\mathrm{R} 2$ & 0.91 & 0.86 & 0.78 & 0.67 \\
\hline RMSE & 9.91 & 12.26 & 0.39 & 0.47 \\
\hline RMSE (no dummies, -Feb. 2020) & 8.93 & 11.29 & 0.38 & 0.47 \\
\hline
\end{tabular}

Data sources: Mortgage Bankers Association (MBA), J.P. Morgan Markets, and Freddie Mac 30-Year Fixed Rate Mortgage Average in the United States [MORTGAGE30US] and Board of Governors of the Federal Reserve System (US) 10-Year Treasury Constant Maturity Rate [DGS10], both retrieved from FRED, Federal Reserve Bank of St. Louis. MBA applications index is a three-week backward-looking moving average. Models include month-of-year dummies (coefficients not displayed). Newey-West standard errors (6 lags) in parentheses. ${ }^{*} \sim p<0.10,{ }^{*} p<0.05,{ }^{* *} p<0.01,{ }^{* * *} p<0.001$. 


\section{Table 2: Changes in Fintech Mortgage Lending During the Pandemic}

Dependent variable $=100$ if mortgage originator is a fintech lender, zero otherwise

\begin{tabular}{|c|c|c|c|c|c|c|c|c|c|}
\hline & $(1)$ & $(2)$ & (3) & (4) & (5) & (6) & (7) & (8) & (9) \\
\hline & \multicolumn{3}{|c|}{ Purchase Mortgages } & \multicolumn{3}{|c|}{ Refinancings } & \multicolumn{3}{|c|}{ All Loans } \\
\hline Pandemic & $\begin{array}{c}2.77^{* * * *} \\
(0.27)\end{array}$ & $\begin{array}{c}2.11^{* * *} \\
(0.28)\end{array}$ & $\begin{array}{c}1.39^{* * *} \\
(0.27)\end{array}$ & $\begin{array}{l}-0.22 \\
(0.52)\end{array}$ & $\begin{array}{l}-0.24 \\
(0.26)\end{array}$ & $\begin{array}{l}-0.83^{*} \\
(0.33)\end{array}$ & $\begin{array}{c}3.80^{* * *} \\
(0.24)\end{array}$ & $\begin{array}{l}0.76^{* *} \\
(0.24)\end{array}$ & $\begin{array}{c}0.06 \\
(0.24)\end{array}$ \\
\hline $\begin{array}{l}\text { Pandemic } \times \\
\text { FICO }<680\end{array}$ & & & $\begin{array}{c}2.69^{* * *} \\
(0.27)\end{array}$ & & & $\begin{array}{c}4.10^{* * *} \\
(0.41)\end{array}$ & & & $\begin{array}{c}3.48^{* * *} \\
(0.28)\end{array}$ \\
\hline Num obs. & 5284401 & 5284401 & 5284401 & 7054698 & 7054698 & 7054698 & 12339099 & 12339099 & 12339099 \\
\hline Mean of dep. var. & 11.09 & 11.09 & 11.09 & 24.91 & 24.91 & 24.91 & 19.00 & 19.00 & 19.00 \\
\hline Loan controls & $\mathrm{N}$ & Y & $\mathrm{Y}$ & $\mathrm{N}$ & $\mathrm{Y}$ & Y & $\mathrm{N}$ & Y & Y \\
\hline FICO $<680$ dummy & $\mathrm{N}$ & $\mathrm{N}$ & $\mathrm{Y}$ & $\mathrm{N}$ & $\mathrm{N}$ & $\mathrm{Y}$ & $\mathrm{N}$ & $\mathrm{N}$ & $\mathrm{Y}$ \\
\hline
\end{tabular}

Notes: Fintech lenders are identified based on the classification in Fuster et al. (2019). Pandemic dummy = 1 if estimated origination date is April 2020 or later. Loan controls include: state dummies; government agency dummies (Fannie Mae, Freddie Mac, FHA, VA, RHS and Section 184 Indian home); dummies for refinancing and cash-out refinancing; debt-to-income (DTI), DTI $^{2}$, loan-to-value (LTV), LTV $^{2}$, credit score, credit score $^{2}$, loan principal, $\log$ (loan principal), number of borrowers, and a first-time homebuyer dummy. Specifications including a FICO $<680$ interaction term also include an uninteracted FICO $<680$ dummy in the controls. Sample period is January 2019 to December 2020. Linear probability model estimated using eMBS loan-level data on mortgages securitized by Fannie Mae, Freddie Mac and Ginnie Mae. Sample includes nonbank mortgages only. Standard errors clustered by state. $\sim p<0.10,{ }^{*} p<0.05,{ }^{* *} p<0.01$, $* * * p<0.001$. 
Table 3: Metro Area Differences in Conventional Conforming Mortgage Rates (\%)

\begin{tabular}{|c|c|c|c|c|c|c|}
\hline & (1) & $(2)$ & (3) & (4) & (5) & (6) \\
\hline \multicolumn{7}{|l|}{ Virus spread: } \\
\hline COVID cases per capita & $\begin{array}{c}-0.0032^{* * *} \\
(0.0008)\end{array}$ & & & & & \\
\hline Dummy: MSA in top quartile & & $\begin{array}{c}-0.0178^{* * *} \\
(0.0051)\end{array}$ & & & & $\begin{array}{c}-0.0183^{* * *} \\
(0.0051)\end{array}$ \\
\hline \multicolumn{7}{|l|}{ Unemployment: } \\
\hline Year-over-year change in U.R. & & & $\begin{array}{l}0.0112 * \\
(0.0054)\end{array}$ & & & $\begin{array}{l}0.0118^{*} \\
(0.0051)\end{array}$ \\
\hline \multicolumn{7}{|l|}{ Market concentration: } \\
\hline COVID $\times$ top 4 share & & & & $\begin{array}{c}0.0025 \\
(0.0042)\end{array}$ & & $\begin{array}{c}0.0001 \\
(0.0041)\end{array}$ \\
\hline COVID $\times$ HHI & & & & & $\begin{array}{c}0.0048 \\
(0.0042)\end{array}$ & \\
\hline Geographic FE & yes & yes & yes & yes & yes & yes \\
\hline Loan controls $\times$ week FE & yes & yes & yes & yes & yes & yes \\
\hline $\mathrm{N}$ & $1,130,086$ & $1,130,086$ & $1,130,086$ & $1,130,086$ & $1,130,086$ & $1,130,086$ \\
\hline
\end{tabular}

Data Sources: Optimal Blue locks data, New York Times COVID data, Bureau of Labor Statistics unemployment data, and Home Mortgage Disclosure Act data. Notes: Sample includes loans locked from November 2019 to August 2020 in the 100 largest CBSAs. Standard errors in parentheses, clustered at CBSA level. COVID cases per 1,000 are lagged one month. The top 4 lenders' market share, HHI, and year-over-year unemployment are all standardized with mean of 0 and standard deviation of 1 . Mortgage interest rates are adjusted for points paid by borrower (credits received from lender). Additional controls include CBSA-level fixed effects, as well as lock week interacted with loan characteristics: binned FICO score, binned loan-to-value ratio, interest rate type (fixed-rate, 5/1 ARM, 7/1 ARM, or 10/1 ARM), and loan purpose (purchase vs. refinance). $\sim p<0.10,{ }^{*} p<0.05,{ }^{* *} p<0.01,{ }^{* * *} p<0.001$. 


\section{Table 4: Changes in Jumbo Lending During the Pandemic}

\section{A. Change in jumbo share}

Dependent Variable $=100$ if mortgage balance exceeds conforming limit

\begin{tabular}{lcccccc}
\hline \hline & $(1)$ & $(2)$ & $(3)$ & $(4)$ & $(5)$ & $(6)$ \\
\hline Pandemic & $-8.027^{* * *}$ & $-6.691^{* * *}$ & $-8.990^{* * *}$ & $-6.582^{* * *}$ & $-8.614^{* * *}$ & $-6.756^{* * *}$ \\
& $(0.166)$ & $(0.149)$ & $(0.204)$ & $(0.165)$ & $(0.144)$ & $(0.117)$ \\
\hline $\mathrm{N}$ & 270292 & 267645 & 299819 & 297252 & 589233 & 586663 \\
Mean $\mathrm{Y}$ & 15.06 & 15.09 & 14.40 & 14.44 & 15.13 & 15.14 \\
Origination type & Purchase & Purchase & Refinance & Refinance & All & All \\
Loan controls & $\mathrm{N}$ & $\mathrm{Y}$ & $\mathrm{N}$ & $\mathrm{Y}$ & $\mathrm{N}$ & $\mathrm{Y}$ \\
\hline
\end{tabular}

\section{B. Change in jumbo and super-conforming share, high-cost areas only}

Dependent Variable $=100$ if mortgage is above national or local conforming loan limit

\begin{tabular}{lccccccc}
\hline \hline & \multicolumn{3}{c}{$>$ national CLL } & & \multicolumn{3}{c}{$>$ local CLL } \\
\cline { 2 - 4 } & $(1)$ & $(2)$ & $(3)$ & & $(4)$ & $(5)$ & $(6)$ \\
\hline Pandemic & $-5.175^{* * *}$ & $-6.487^{* * *}$ & $-7.825^{* * *}$ & & $-8.604^{* * *}$ & $-12.68^{* * *}$ & $-11.14^{* * *}$ \\
& $(0.319)$ & $(0.191)$ & $(0.179)$ & & $(0.293)$ & $(0.372)$ & $(0.273)$ \\
\hline $\mathrm{N}$ & 152005 & 325164 & 492240 & & 99478 & 133618 & 242839 \\
Mean $\mathrm{Y}$ & 35.59 & 27.02 & 29.76 & & 20.61 & 19.38 & 20.55 \\
Origination type & Purchase & Refinance & All & & Purchase & Refinance & All \\
Loan controls & $\mathrm{Y}$ & $\mathrm{Y}$ & $\mathrm{Y}$ & & $\mathrm{Y}$ & $\mathrm{Y}$ & $\mathrm{Y}$ \\
\hline
\end{tabular}

Notes: Linear probability model, estimated using McDash loan-level data. Sample includes loans within $10 \%$ either side of the conforming loan limit (CLL) applicable to each loan (either the national or county-level limit, whichever is applicable). In panel B, sample is restricted to "high-cost" counties where the county-level CLL exceeds the national CLL. Pandemic dummy = 1 if origination date is April 2020 or later. Loan controls include: zip code dummies, debt-to-income (DTI), DTI ${ }^{2}$, loan-to-value (LTV), LTV ${ }^{2}$, credit score, credit score ${ }^{2}$, appraisal amount, and $\log$ (appraisal amount). Sample period is January 2019 to October 2020. $\sim p<0.10,{ }^{*} p<0.05,{ }^{* *} p<0.01,{ }^{* * *} p<0.001$. Robust standard errors in parentheses clustered at zip code level. 


\section{Internet Appendix for "How Resilient Is Mortgage Credit Supply? Evidence from the COVID-19 Pandemic"}

Andreas Fuster, Aurel Hizmo, Lauren Lambie-Hanson, James Vickery and Paul Willen 


\section{A Additional Evidence on Intermediation Markups}

\section{A.1 Evolution of Servicing Multiples}

\section{Figure A.1: Base Servicing Multiples for Conforming and FHA Mortgages}

A. Conforming Mortgages

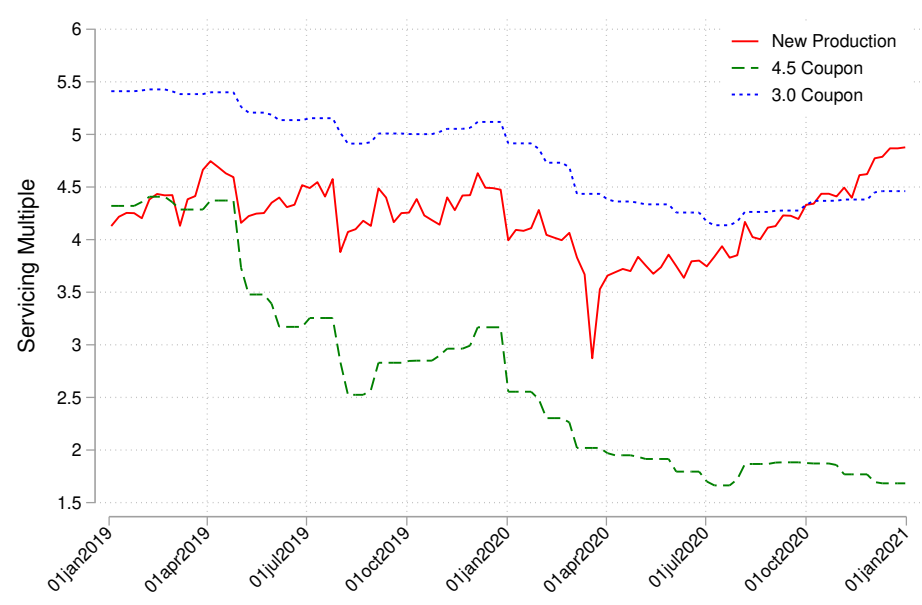

B. FHA Mortgages

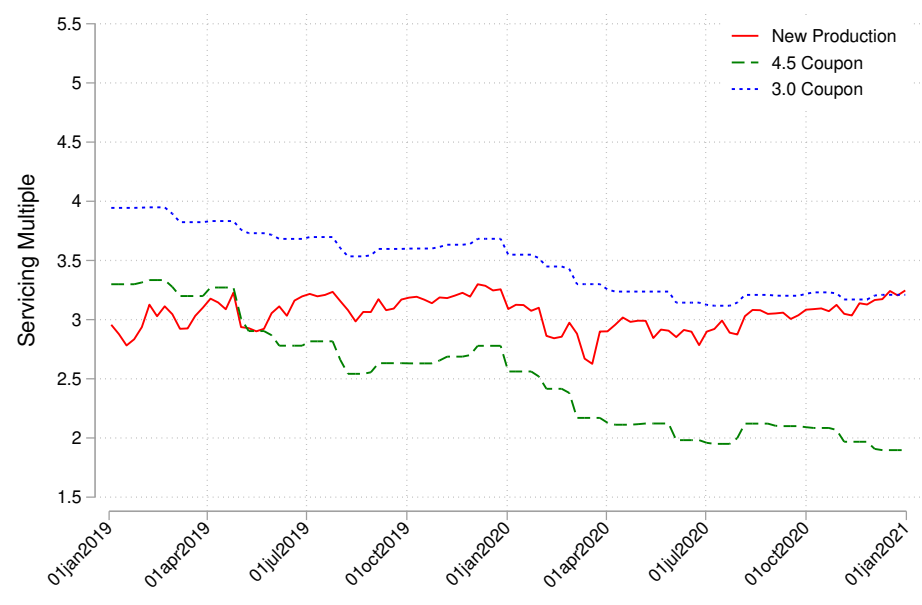

Data sources: SitusAMC for servicing multiples; Freddie Mac PMMS (panel A) and MBA (panel B) for mortgage rates. "New Production" interpolates between specific coupons (two examples of which are shown) to obtain servicing multiples for a loan originated at the primary market mortgage rate adjusted for discount points. 


\section{A.2 Alternative Measures for Conventional Conforming Market}

Figure A.2: Primary-Secondary Spread Using the Current Coupon: Conforming Market

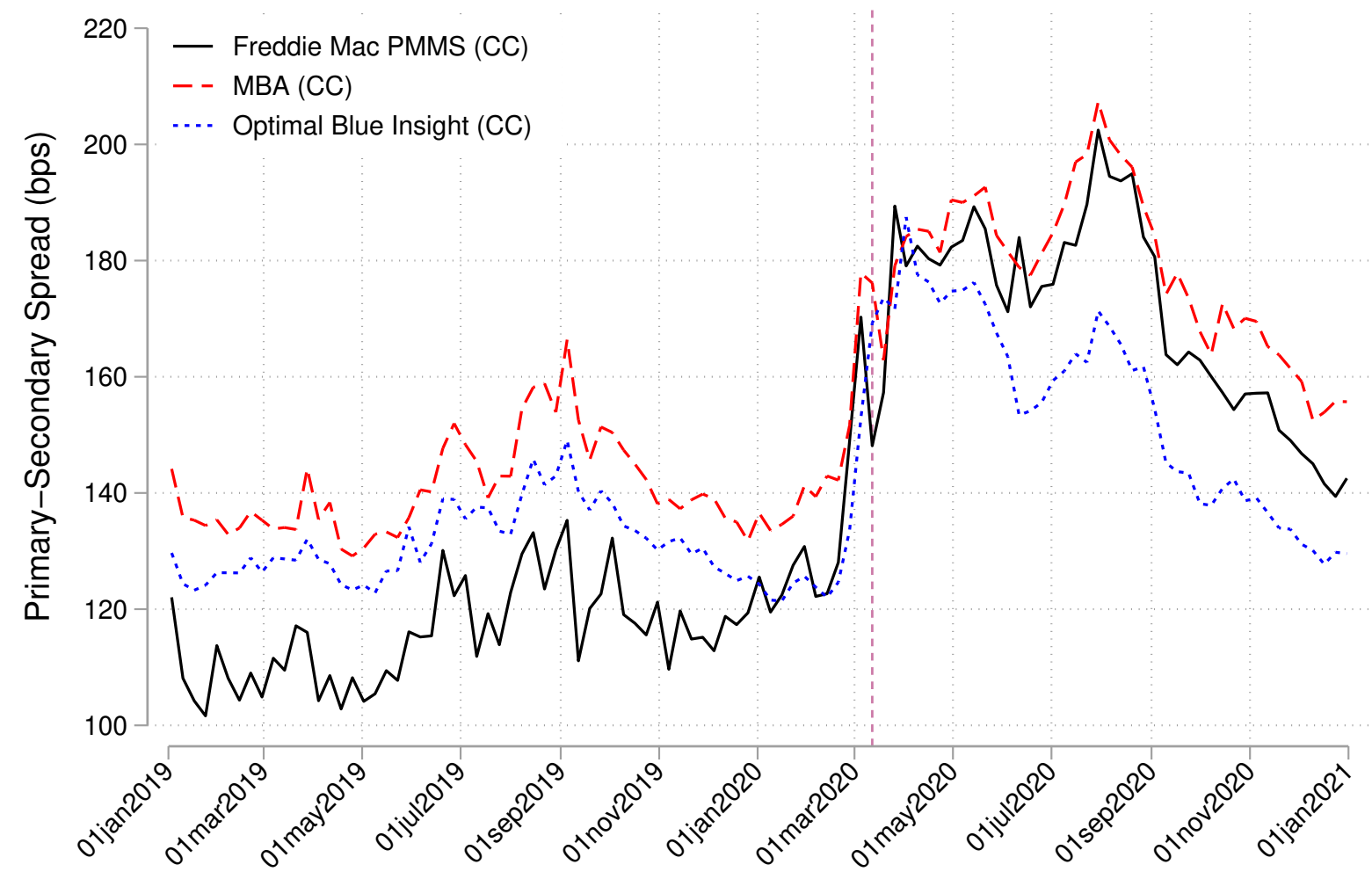

Notes: Vertical line represents the declaration of a national state of emergency in March 13th, 2020. Data sources: Optimal Blue, J.P. Morgan Markets, MBA (via Haver Analytics). 


\section{Figure A.3: Evolution of Originator Profits and Unmeasured Costs (OPUC)}

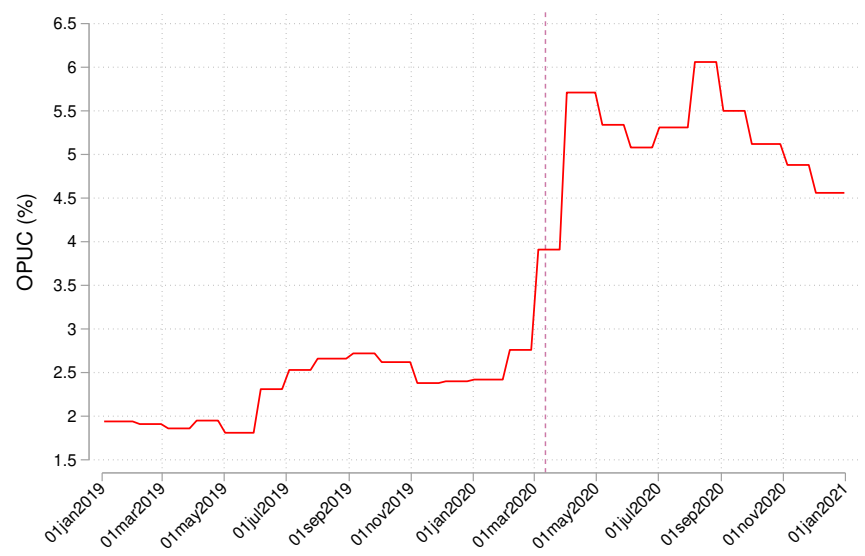

Notes: Vertical line represents the declaration of a national state of emergency in March 13th, 2020. Data source: https://www.newyorkfed.org/research/epr/2013/1113fust.html.

\section{Figure A.4: OPUC and Mortgage Demand}

OPUC vs. Refinance Incentive

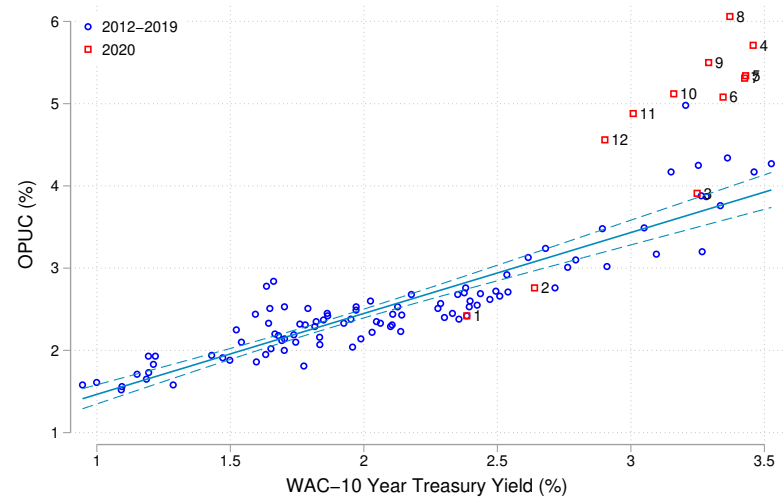

OPUC vs. Applications

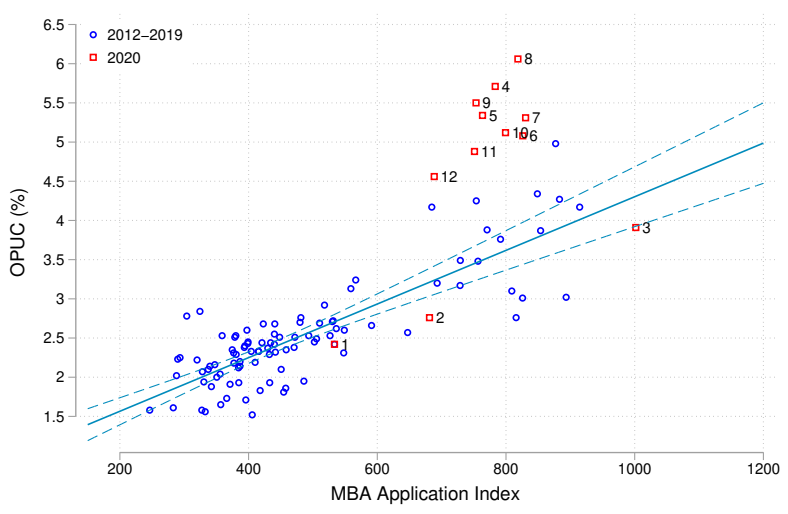

Data source: https : //www. newyorkfed.org/research/epr/2013/1113fust.html. 


\section{A.3 FHA Mortgages}

\section{Figure A.5: Comparing Measures of Primary-Secondary Spread: FHA Market}

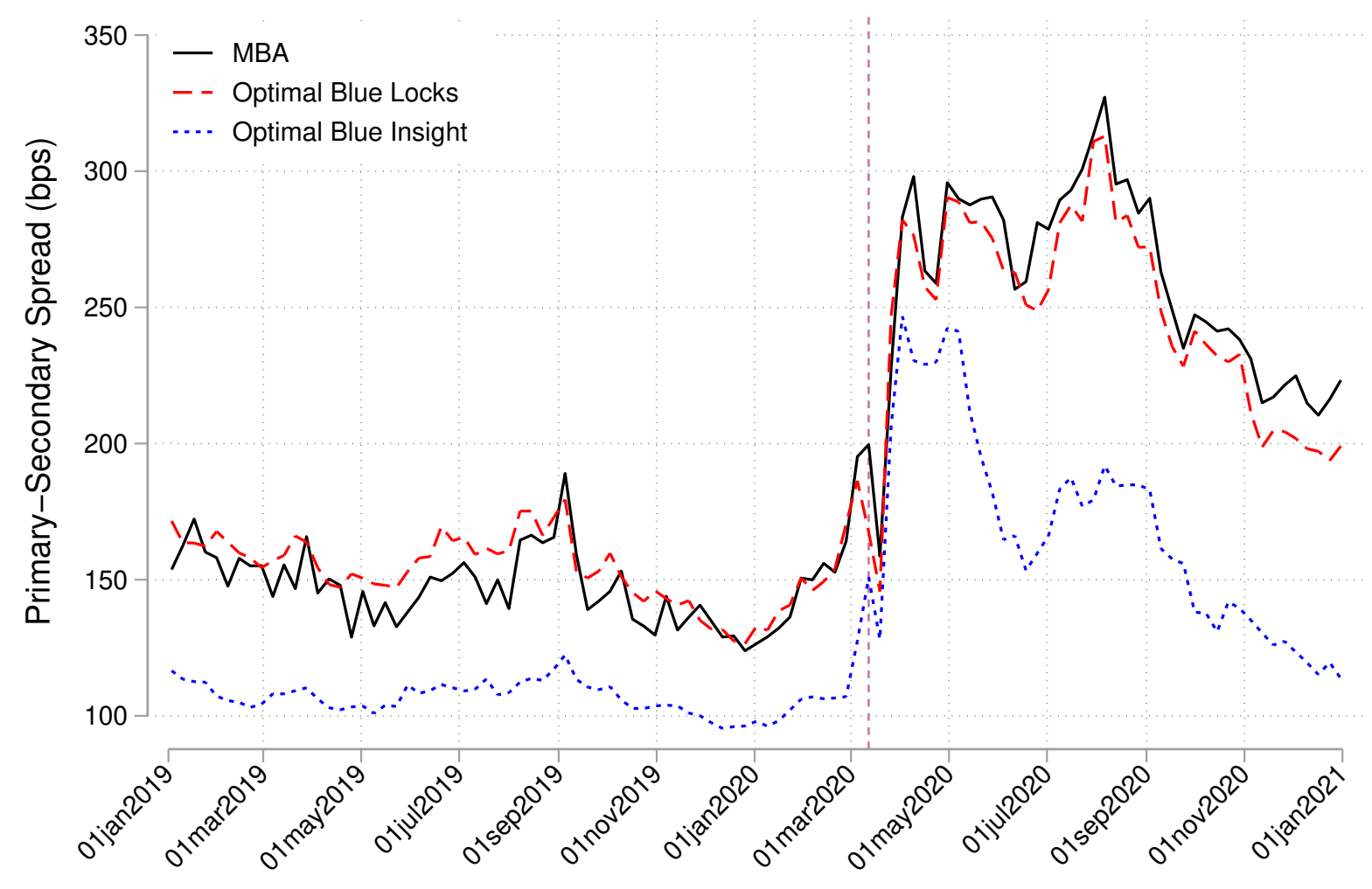

Notes: Primary-secondary spread computed based on the methodology described in Section III.C. Vertical line represents the declaration of a national state of emergency on March 13, 2020. Data sources: Optimal Blue, J.P. Morgan Markets, MBA (via Haver Analytics). 
Figure A.6: Comparing Measures of Gain-on-sale: FHA Market

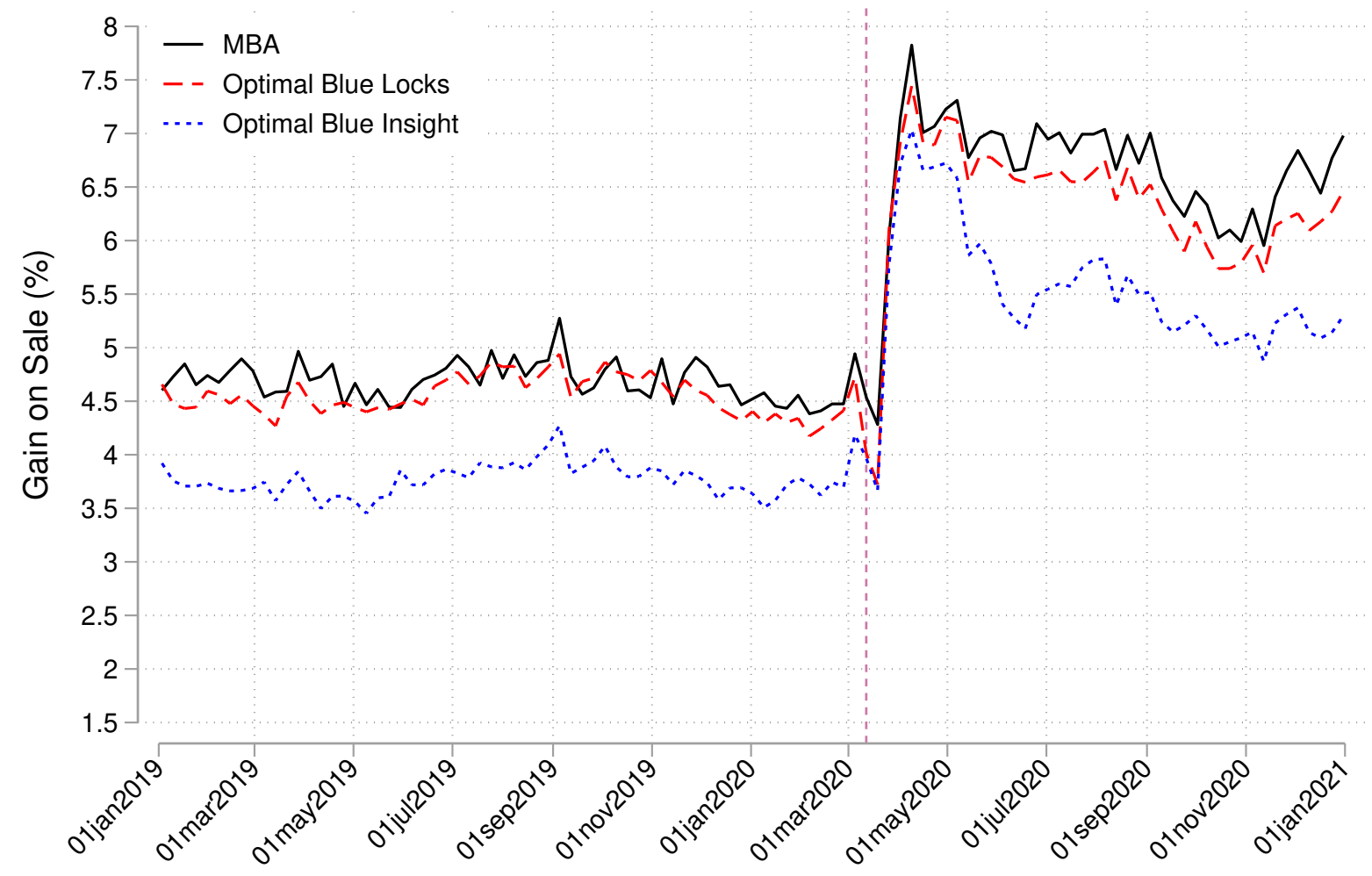

Notes: Computed based on the methodology described in Section III.C. Vertical line represents the declaration of a national state of emergency on March 13, 2020. Data sources: Optimal Blue, J.P. Morgan Markets, MBA (via Haver Analytics). 


\section{A.4 Difference in Intermediation Markups between FHA and Conform- ing Market}

Figure A.7: Primary-Secondary Spread: FHA - Conforming

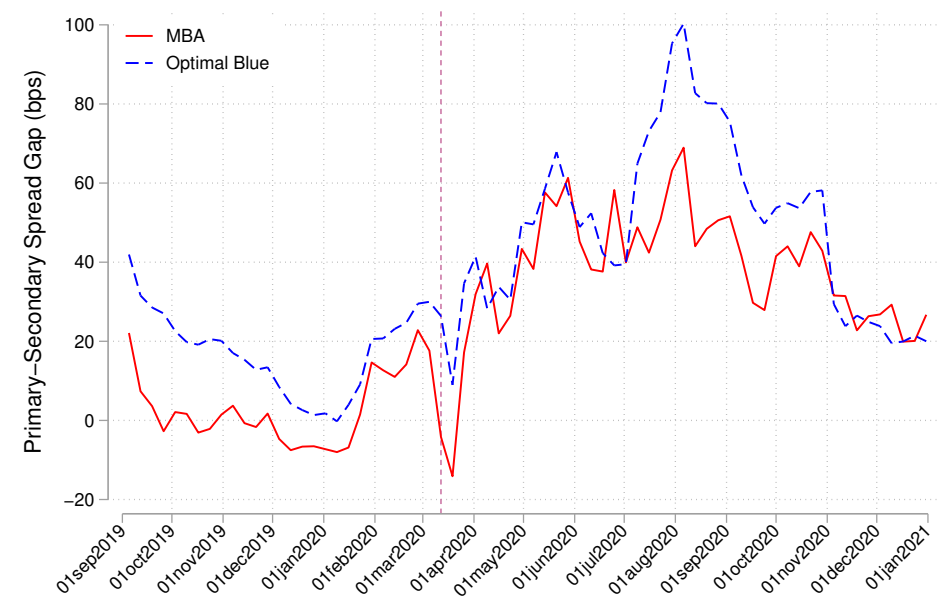

Figure A.8: Gain-on-Sale: FHA - Conforming

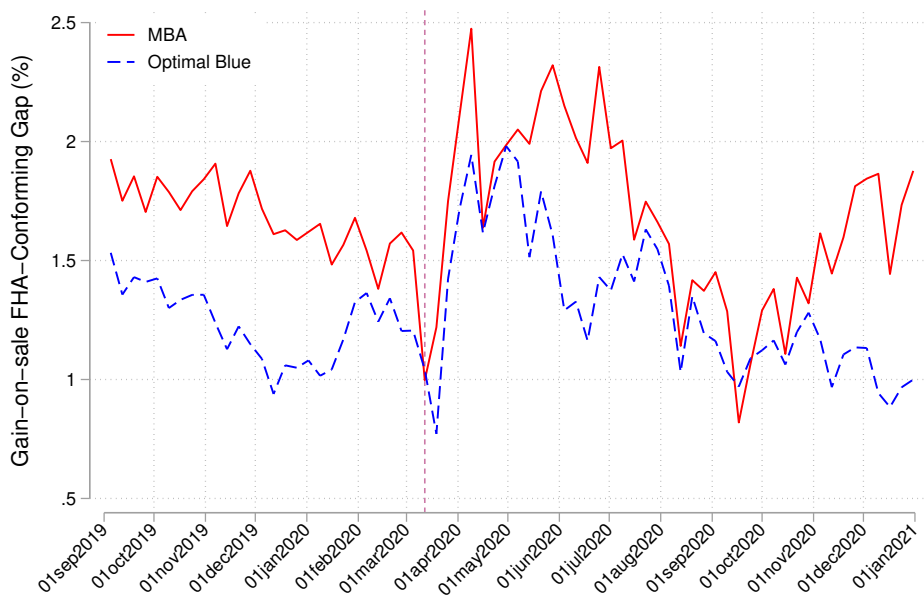

Notes: Vertical line represents the declaration of a national state of emergency on March 13, 2020. Data source: Optimal Blue, JP Morgan Markets, MBA (via Haver Analytics) 


\section{B Labor Market Frictions}

\section{B.1 Postings and Employment Growth}

Table A.1 shows the relationship between job postings for mortgage loan officers and underwriters and employment growth in NAICS codes 522292 (real estate credit at nonbank financial intermediaries) and 52231 (mortgage and nonmortgage loan brokers). Model 1 estimates the relationship using pre-pandemic data only (March 2012 through February 2020). Model 2 adds the pandemic period (through December 2020) and includes a pandemic time dummy.

Table A.1: Mortgage Loan Officer Job Postings and Employment Change.

\begin{tabular}{lcc}
\hline \hline & \multicolumn{2}{c}{ Employment Change } \\
& $(1)$ & $(2)$ \\
\hline Job postings per 100 employees $t$ & $0.0157^{* *}$ & $0.0163^{* * *}$ \\
Job postings per 100 employees $t-1$ & $(0.0053)$ & $(0.0043)$ \\
& $0.0118^{* *}$ & $0.0119^{* * *}$ \\
Job postings per 100 employees $t-2$ & $(0.0044)$ & $(0.0035)$ \\
& -0.0005 & -0.0001 \\
Pandemic & $(0.0055)$ & $(0.0038)$ \\
& & $-0.0152^{* * *}$ \\
Constant & & $(0.0044)$ \\
& & \\
N & $-0.0233^{* * *}$ & $-0.0242^{* * *}$ \\
Mean Y & $(0.0062)$ & $(0.0053)$ \\
Adj. R2 & 96 & 106 \\
Months included & 0.0023 & 0.0037 \\
\hline \hline
\end{tabular}

Data sources: Burning Glass Technologies and Bureau of Labor Statistics Current Employment Statistics data. Newey-West standard errors with 4 lags in parentheses. $\sim p<0.10,{ }^{*} p<0.05,{ }^{* *} p<0.01$, ${ }^{* * *}$ $p<0.001$. 


\section{B.2 Personnel Expenses}

Figure A.9 is based on the MBA Quarterly Performance Report and plots the relationship between the number of loans the average mortgage bank originates in a quarter and its personnel expenses, expressed in basis points of the total amount of loans originated. ${ }^{1}$ Since some personnel expenses are fixed, we expect a decreasing relationship, and the black dots along with the grey line show that from 2015 through 2019, the relationship was indeed strongly and approximately linearly decreasing.

The first quarter of 2020 still appears closely in line with the relationship over the previous years. However, from 2020:Q2 onward, and especially in Q3 and Q4, personnel expenses appear unusually high: Despite large increases in loan originations relative to Q2, personnel expenses increased over those two quarters. This is consistent with the tight labor market for loan officers, underwriters, processors, etc. leading to increases in compensation in order to attract new workers or prevent poaching by competitors.

Quantifying the "excess" expense is not straightforward and depends on the functional form assumption. In columns 1 and 2 of Table A.2, we control for originated loans linearly (either based on the number of loans or the volume in USD), as in the figure. We add four dummies for the four quarters of 2020, which measure the excess in a quarter relative to what would be expected based on the 2015-2019 data. The coefficients for Q3 and Q4 are highly significant and range from 58 to $98 \mathrm{bp}$ - a very large effect.

In columns 3 and 4, we instead use a functional form that appears more appropriate in a situation where part of the cost is strictly fixed, using the inverse of the loan volume as a regressor. Coefficients on the Q3 and Q4 dummies are again strongly significant, but they are of more modest (though still meaningful) size, ranging from 12 to $29 \mathrm{bp}$.

\footnotetext{
${ }^{1}$ We incorporate data only from 2015 onward, since over the preceding years, there was a steady upward trend in expenses for a given level of originations, suggesting cost increases in the wake of the financial crisis (Fuster et al., 2017).
} 
Figure A.9: Personnel Expenses vs. Origination Volumes

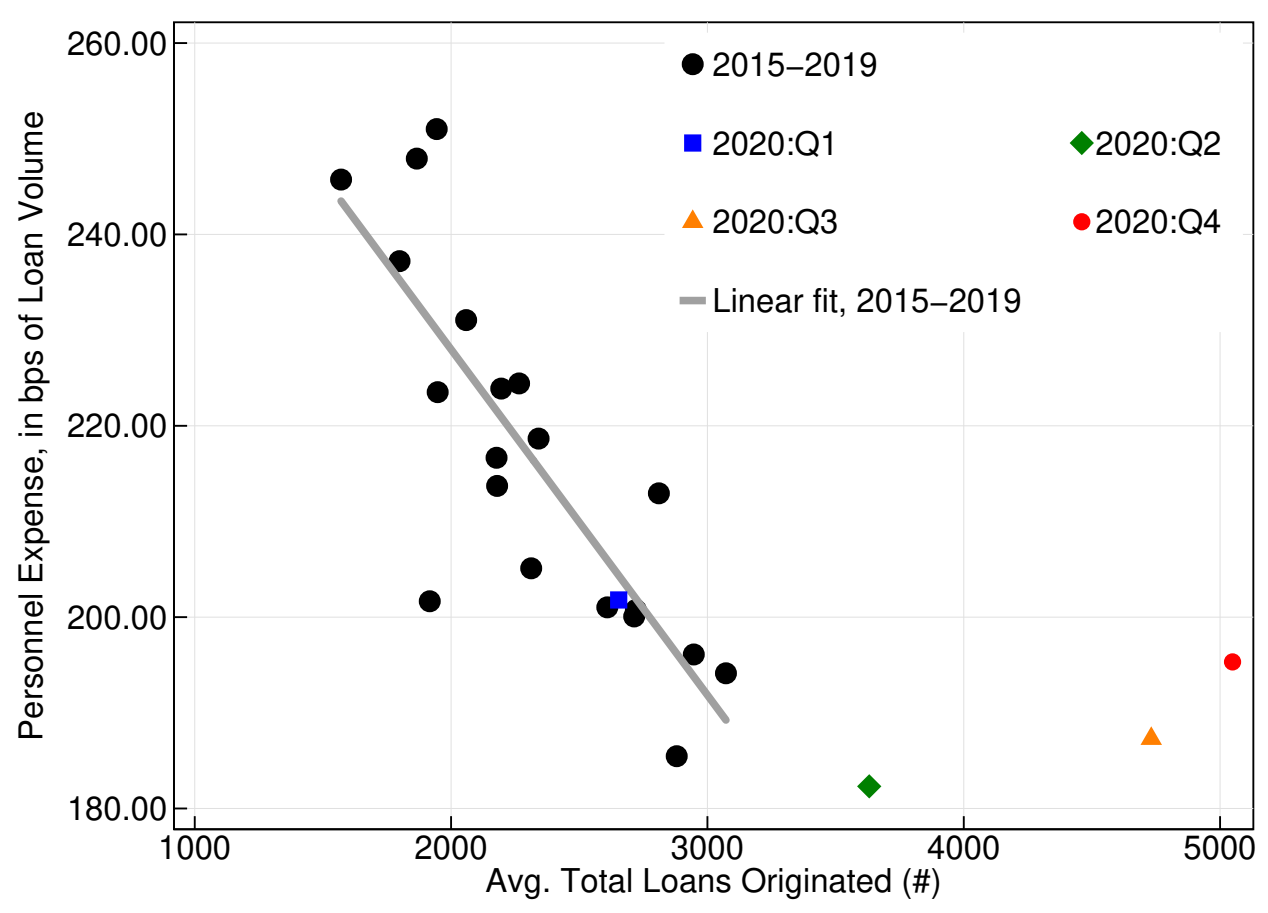

Data source: Mortgage Bankers Association Quarterly Performance Report. 
Table A.2: Regression Evidence on Excess Personnel Expenses (in Basis Points) of Mortgage Banks in 2020

\begin{tabular}{|c|c|c|c|c|}
\hline & $(1)$ & $(2)$ & (3) & $(4)$ \\
\hline Avg. originated loans & $\begin{array}{c}-0.036^{* * *} \\
(0.005)\end{array}$ & & & \\
\hline Avg. originated loans $(\$ \mathrm{~m})$ & & $\begin{array}{c}-0.132^{* * *} \\
(0.016)\end{array}$ & & \\
\hline$-1 /$ Avg. originated loans & & & $\begin{array}{c}-185283.904^{* * *} \\
(25269.144)\end{array}$ & \\
\hline$-1 /$ Avg. originated loans $(\$ \mathrm{~m})$ & & & & $\begin{array}{c}-44101.600^{* * *} \\
(4743.749)\end{array}$ \\
\hline 2020:Q1 & $\begin{array}{l}-2.563 \\
(3.027)\end{array}$ & $\begin{array}{l}5.987^{* *} \\
(2.584)\end{array}$ & $\begin{array}{l}-1.885 \\
(2.745)\end{array}$ & $\begin{array}{l}5.089^{* *} \\
(1.831)\end{array}$ \\
\hline 2020:Q2 & $\begin{array}{l}13.262^{*} \\
(6.417)\end{array}$ & $\begin{array}{c}24.844^{* * *} \\
(6.091)\end{array}$ & $\begin{array}{l}-2.576 \\
(3.676)\end{array}$ & $\begin{array}{c}2.869 \\
(2.586)\end{array}$ \\
\hline 2020:Q3 & $\begin{array}{c}57.994^{* * *} \\
(11.620)\end{array}$ & $\begin{array}{c}71.610^{* * *} \\
(10.864)\end{array}$ & $\begin{array}{c}14.272^{* * *} \\
(4.904)\end{array}$ & $\begin{array}{c}18.113^{* * *} \\
(3.454)\end{array}$ \\
\hline 2020:Q4 & $\begin{array}{c}77.473^{* * *} \\
(13.169)\end{array}$ & $\begin{array}{c}97.695^{* * *} \\
(12.977)\end{array}$ & $\begin{array}{c}24.756^{* * *} \\
(5.186)\end{array}$ & $\begin{array}{c}29.208^{* * *} \\
(3.739)\end{array}$ \\
\hline Constant & $\begin{array}{c}300.235^{* * *} \\
(12.881)\end{array}$ & $\begin{array}{c}291.949^{* * *} \\
(10.715)\end{array}$ & $\begin{array}{c}133.866^{* * *} \\
(9.798)\end{array}$ & $\begin{array}{c}136.158^{* * *} \\
(6.735)\end{array}$ \\
\hline Avg. Y & 212.41 & 212.41 & 212.41 & 212.41 \\
\hline SD Y & 19.93 & 19.93 & 19.93 & 19.93 \\
\hline Adj. R2 & 0.68 & 0.71 & 0.68 & 0.74 \\
\hline Obs. & 24 & 24 & 24 & 24 \\
\hline
\end{tabular}




\section{Additional Evidence on Fintech Market Share}

\section{C.1 Analysis Including Banks in the Sample}

Table A.3 repeats the analysis from Table 2 retaining mortgages originated by banks in the sample (banks are identified by name in the eMBS data). As the table shows, fintech lenders gain market share, particularly for purchase mortgages and low-credit-score loans. The change in the fintech share is more positive than in our main analysis, because of a substitution from banks to nonbanks during the pandemic.

\section{Table A.3: Fintech Lending During the Pandemic: Sample Retaining Bank Loans}

\begin{tabular}{|c|c|c|c|c|c|c|c|c|c|}
\hline & $(1)$ & $(2)$ & (3) & (4) & (5) & (6) & (7) & (8) & (9) \\
\hline & \multicolumn{3}{|c|}{ Purchase Mortgages } & \multicolumn{3}{|c|}{ Refinancings } & \multicolumn{3}{|c|}{ All Loans } \\
\hline Pandemic & $\begin{array}{c}2.46^{* * *} \\
(0.23)\end{array}$ & $\begin{array}{c}2.31^{* * *} \\
(0.21)\end{array}$ & $\begin{array}{c}1.88^{* * *} \\
(0.20)\end{array}$ & $\begin{array}{c}0.34 \\
(0.57)\end{array}$ & $\begin{array}{c}1.93^{* * *} \\
(0.23)\end{array}$ & $\begin{array}{c}1.64^{* * *} \\
(0.26)\end{array}$ & $\begin{array}{c}3.23^{* * *} \\
(0.33)\end{array}$ & $\begin{array}{c}1.81^{* * *} \\
(0.20)\end{array}$ & $\begin{array}{c}1.46^{* * *} \\
(0.22)\end{array}$ \\
\hline $\begin{array}{l}\text { Pandemic } \times \\
\text { FICO }<680\end{array}$ & & & $\begin{array}{c}2.07^{* * *} \\
(0.25)\end{array}$ & & & $\begin{array}{c}2.56^{* * *} \\
(0.25)\end{array}$ & & & $\begin{array}{c}2.14^{* * *} \\
(0.23)\end{array}$ \\
\hline Num obs. & 7288633 & 7288633 & 7288633 & 9807494 & 9807494 & 9807494 & 17096127 & 17096127 & 17096127 \\
\hline Mean of dep. var. & 8.04 & 8.04 & 8.04 & 17.92 & 17.92 & 17.92 & 13.71 & 13.71 & 13.71 \\
\hline Loan controls & $\mathrm{N}$ & $\mathrm{Y}$ & $\mathrm{Y}$ & $\mathrm{N}$ & $\mathrm{Y}$ & Y & $\mathrm{N}$ & Y & Y \\
\hline FICO $<680$ dummy & $\mathrm{N}$ & $\mathrm{N}$ & $\mathrm{Y}$ & $\mathrm{N}$ & $\mathrm{N}$ & $\mathrm{Y}$ & $\mathrm{N}$ & $\mathrm{N}$ & $\mathrm{Y}$ \\
\hline
\end{tabular}

Notes: Fintech lenders are identified based on the classification in Fuster et al. (2019). Pandemic dummy = 1 if estimated origination date is April 2020 or later. Loan controls include: state dummies; government agency dummies (Fannie Mae, Freddie Mac, FHA, VA, RHS and Section 184 Indian home); dummies for refinancing and cash-out refinancing; debt-to-income (DTI), $\mathrm{DTI}^{2}$, loan-to-value (LTV), $\mathrm{LTV}^{2}$, credit score, credit score ${ }^{2}$, loan principal, $\log (\operatorname{loan}$ principal), number of borrowers, and a first-time homebuyer dummy. Specifications including a FICO $<680$ interaction term also include an uninteracted FICO $<680$ dummy in the controls. Sample period is January 2019 to December 2020. Linear probability model estimated using eMBS loan-level data on mortgages securitized by Fannie Mae, Freddie Mac and Ginnie Mae. Standard errors clustered by state. $\sim p<0.10,{ }^{*} p<0.05,{ }^{* *} p<0.01,{ }^{* * *} p<0.001$.

\section{C.2 Time-series of Fintech Market Share}

Figure A.10 displays coefficients on a vector of monthly time dummies from a loan-level linear probability regression of whether the mortgage is originated by a fintech lender. Estimates are normalized so that the fitted value equals the actual value in January 2020. The regressions used to generate the figures match the models in Table 2. The left-hand panels reflect the unconditional share, while the right-hand panels control for loan and borrower characteristics. The sample period is January 2019 through December 2020. The eMBS sample for this analysis excludes bank loans. 


\title{
Figure A.10: Time-series of Estimated Fintech Market Share
}

\author{
No controls \\ Loan/borrower controls
}

\section{A. Purchase mortgages}
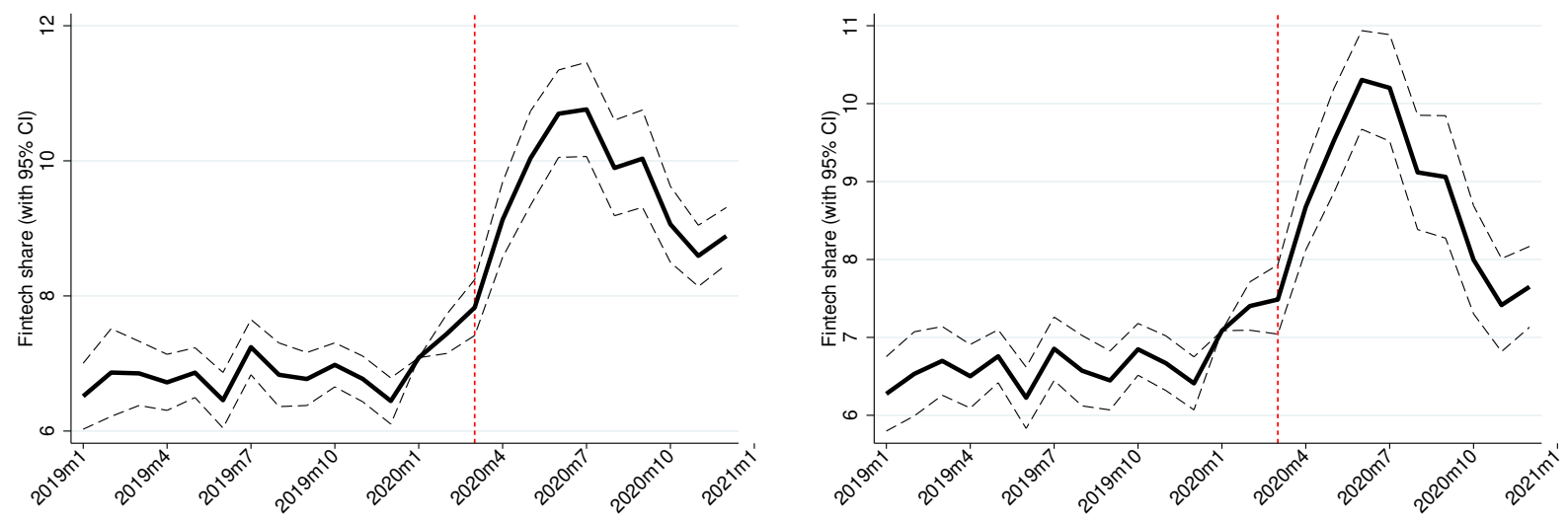

B. Refinancings
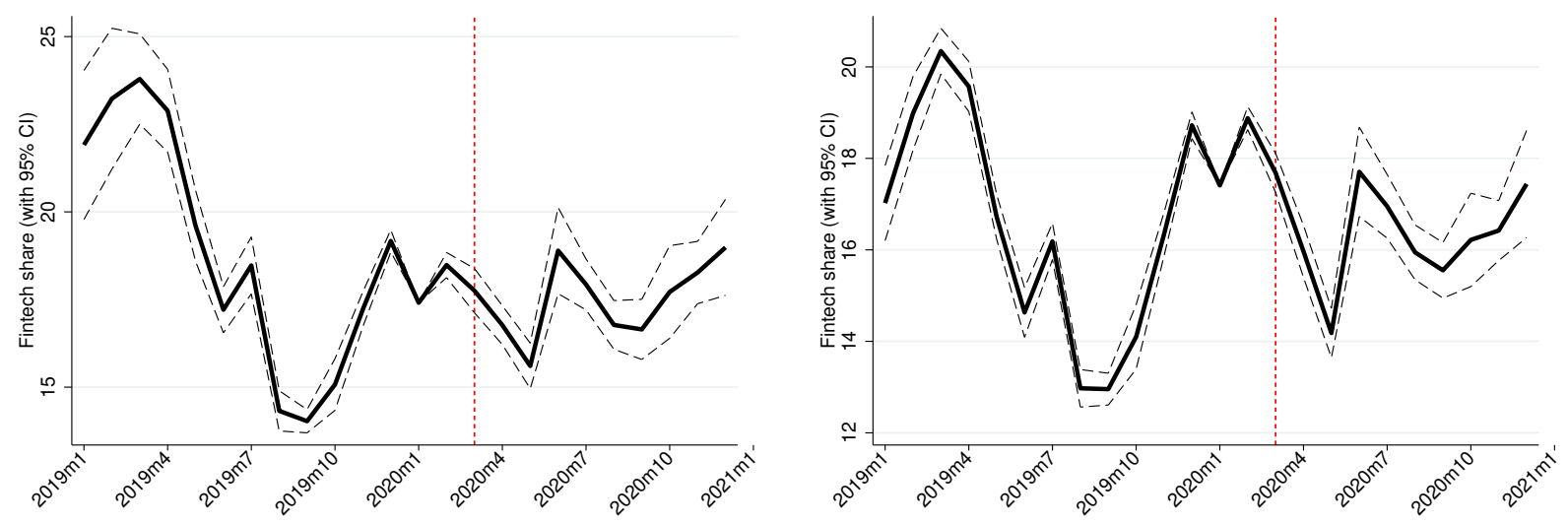

C. All mortgages
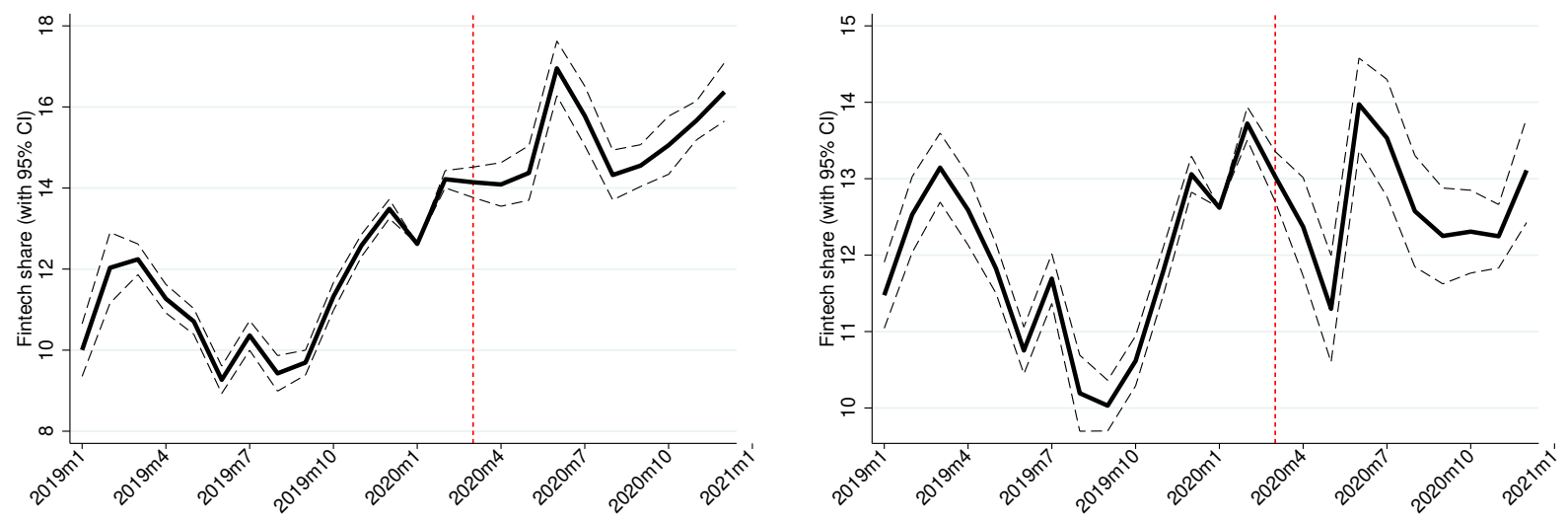

Estimates from linear probability regressions of a fintech lender dummy on a vector of time dummies and, in the right-hand figures, a set of loan and borrower controls (see Table 2 for full list of controls). Sample restricted to nonbank loans. 95\% confidence intervals shown, based on standard errors clustered by state. Data source: eMBS. 


\section{Additional Evidence on Rate Differences across MSAs and Competition}

Figure A.11: Market Concentration in the Conventional/Conforming Loan Market

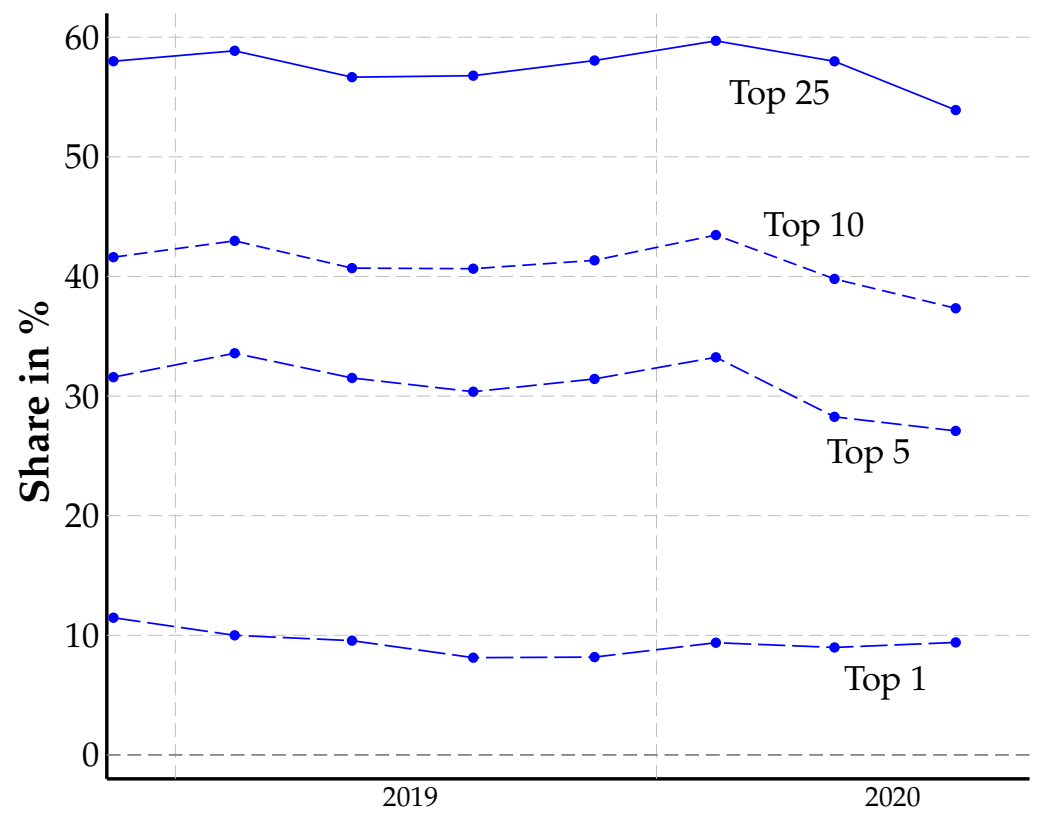

Figure shows the quarterly market share (based on dollar volumes of originations) of the top $N$ firms from 2018:Q4 through 2020:Q3. Data source: Inside Mortgage Finance. 
Figure A.12: Conforming Mortgage Rates for 20 CBSAs (Optimal Blue Insights Data)

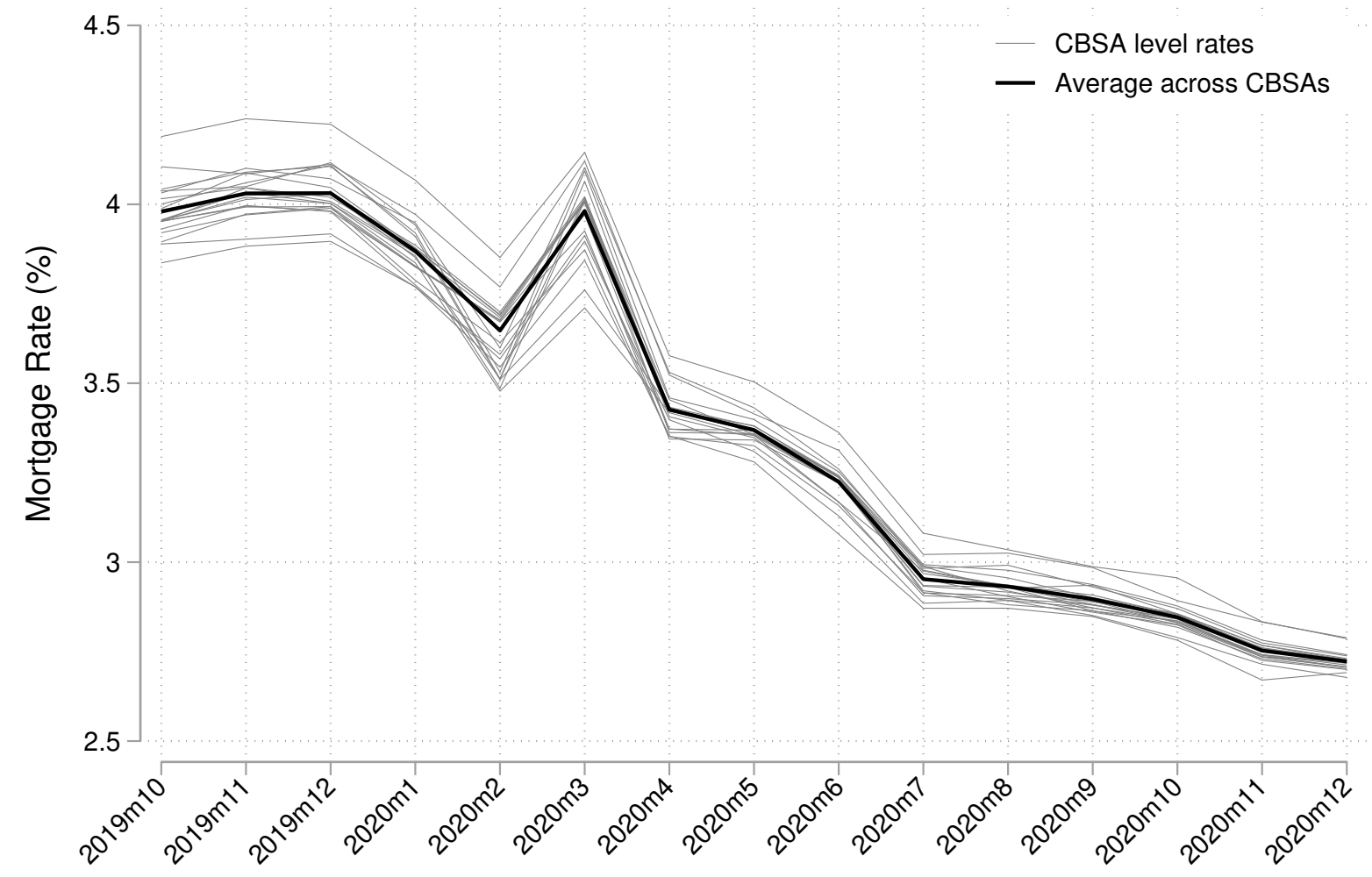

Data source: Optimal Blue 
Table A.4: Metro Area Differences in Conventional Conforming Mortgage Rates (\%): McDash Data.

\begin{tabular}{|c|c|c|c|c|c|c|}
\hline & (1) & $(2)$ & (3) & $(4)$ & (5) & $(6)$ \\
\hline \multicolumn{7}{|l|}{ Virus spread: } \\
\hline COVID cases per capita & $\begin{array}{c}-0.0016^{* *} \\
(0.0006)\end{array}$ & & & & & \\
\hline Dummy: MSA in top quartile & & $\begin{array}{c}-0.0048 \sim \\
(0.0025)\end{array}$ & & & & $\begin{array}{c}-0.0051^{*} \\
(0.0023)\end{array}$ \\
\hline \multicolumn{7}{|l|}{ Unemployment: } \\
\hline Year-over-year change in U.R. & & & $\begin{array}{c}-0.0038 \\
(0.0048)\end{array}$ & & & $\begin{array}{c}-0.0024 \\
(0.0048)\end{array}$ \\
\hline \multicolumn{7}{|l|}{ Market concentration: } \\
\hline COVID $\times$ top 4 share & & & & $\begin{array}{c}-0.0042 \\
(0.0026)\end{array}$ & & $\begin{array}{c}-0.0043 \\
(0.0027)\end{array}$ \\
\hline $\mathrm{COVID} \times \mathrm{HHI}$ & & & & & $\begin{array}{l}-0.0002 \\
(0.0028)\end{array}$ & \\
\hline Geographic FE & yes & yes & yes & yes & yes & yes \\
\hline Loan controls $\times$ week FE & yes & yes & yes & yes & yes & yes \\
\hline $\mathrm{N}$ & $1,007,250$ & $1,007,250$ & $1,007,250$ & $1,007,250$ & $1,007,250$ & $1,007,250$ \\
\hline
\end{tabular}

Data sources: Black Knight McDash data, New York Times COVID data, Bureau of Labor Statistics unemployment data, and Home Mortgage Disclosure Act data. Notes: Sample includes loans locked from November 2019 to August 2020 in the 100 largest CBSAs. Standard errors in parentheses, clustered at CBSA level. COVID cases per 1,000 are lagged one month. The top 4 lenders' market share, HHI, and year-over-year unemployment are all standardized with mean of 0 and standard deviation of 1 . Mortgage interest rates are adjusted for points paid by borrower (credits received from lender). Additional controls include CBSA-level fixed effects, as well as lock week interacted with loan characteristics: binned credit score, binned loan-to-value ratio, interest rate type (fixed-rate, 5/1 ARM, 7/1 ARM, or 10/1 ARM), and loan purpose (purchase vs. refinance). $\sim p<0.10{ }^{*} p<0.05,{ }^{* *} p<0.01,{ }^{* * *} p<0.001$. 


\section{E Mortgage Non-payment by Credit Score Bin}

Figure A.13 below presents a binscatter plot of the proportion of mortgages that were 60-plus days past due as of January 2020 and May 2020. The figure is based on McDash servicing data for mortgages originated since 2017. FHA loans are flagged based on the static loan type field in McDash. Figure A.14 shows the change in the past-due rate from January to June.

As the figures show, non-payment rates have increased across the credit score distribution for GSE, FHA, and portfolio loans. However, the rise in past-due rates is more pronounced for low-credit-score loans, consistent with the expectation that the pandemic has particularly amplified the credit risk for loans to less creditworthy borrowers. Note that a large share of these borrowers took advantage of forbearance programs (An et al., 2021).

Figure A.13: Non-payment vs. Credit Score: Pre-pandemic vs. Pandemic
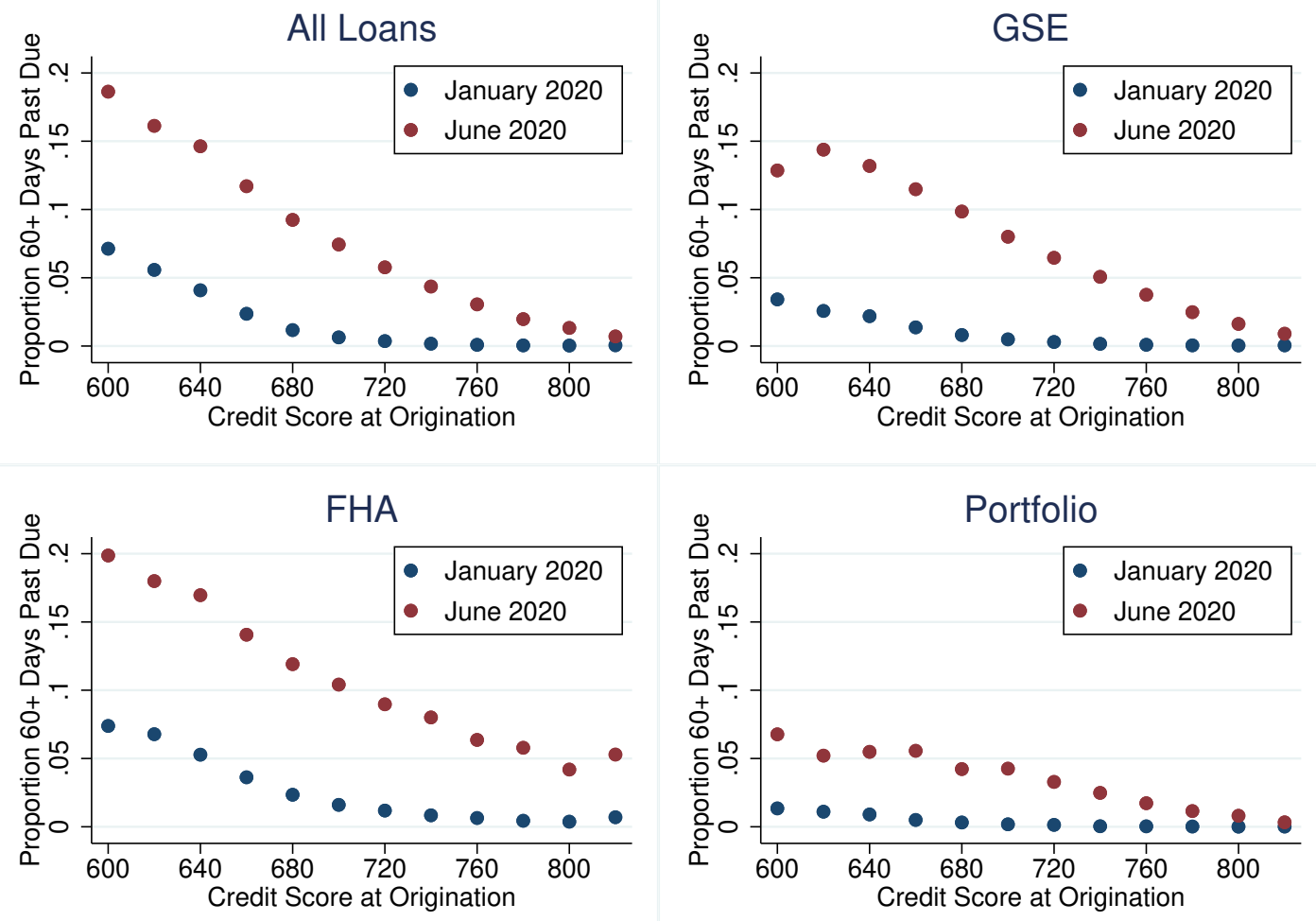

Data source: McDash Data. Note: FHA loans are all classified as FHA, regardless of ownership. Conventional loans are categorized as GSE or portfolio based on the ownership status of the loan at the time of the data snapshot. "All loans" includes FHA, GSE, and conventional loans in portfolio, as well as VA loans and conventional loans held in private-label securities. 
Figure A.14: Non-payment vs. Credit Score: Pre-pandemic vs. Pandemic (Percentage Point Change)

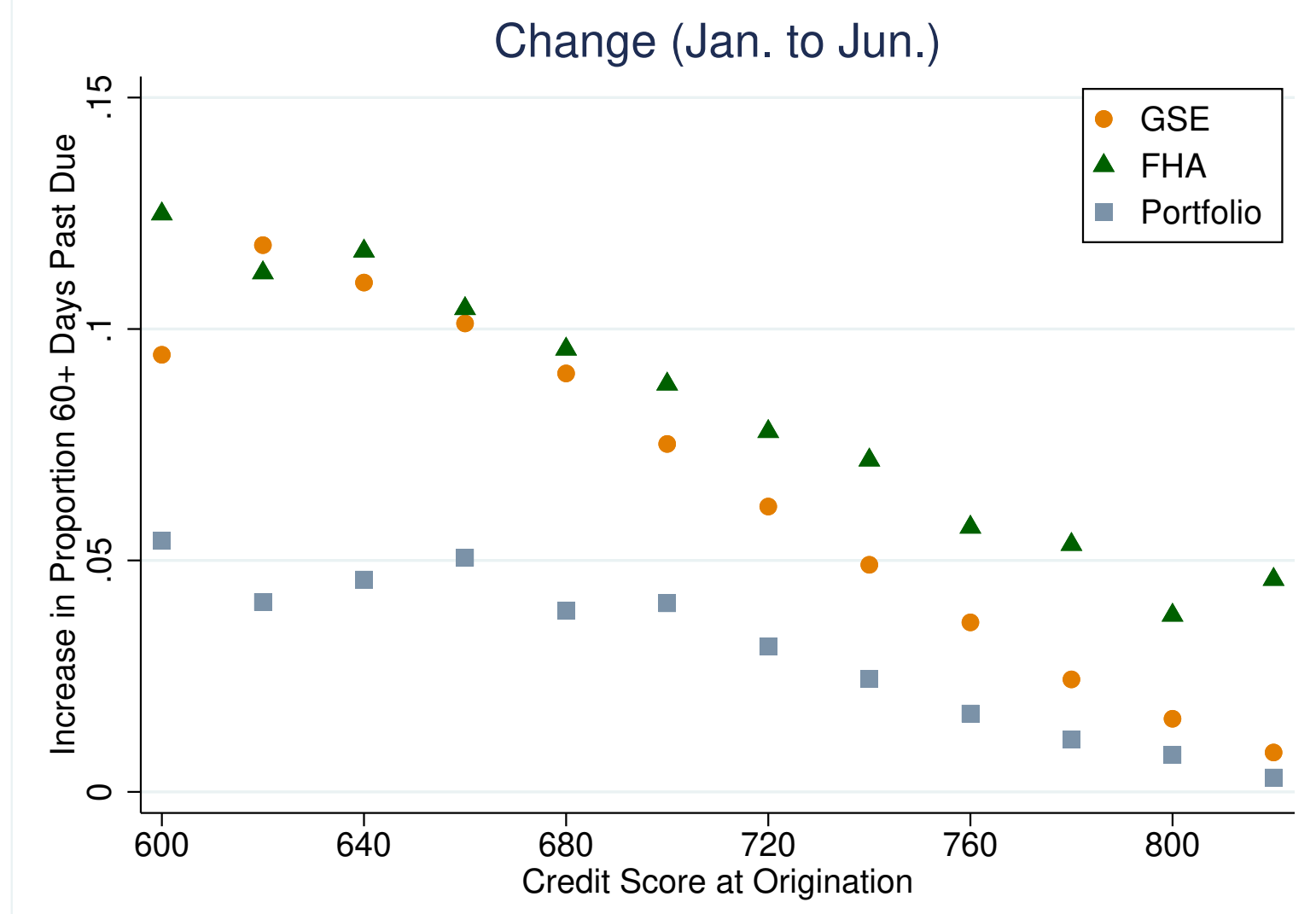

Data source: McDash Data. Note: FHA loans are all classified as FHA, regardless of ownership. Conventional loans are categorized as GSE or portfolio based on the ownership status of the loan at the time of the data snapshot. "All loans" includes FHA, GSE, and conventional loans in portfolio, as well as VA loans and conventional loans held in private-label securities. 


\section{F Credit Score Distributions}

Figure A.15: Credit Score Distribution: Conventional Conforming

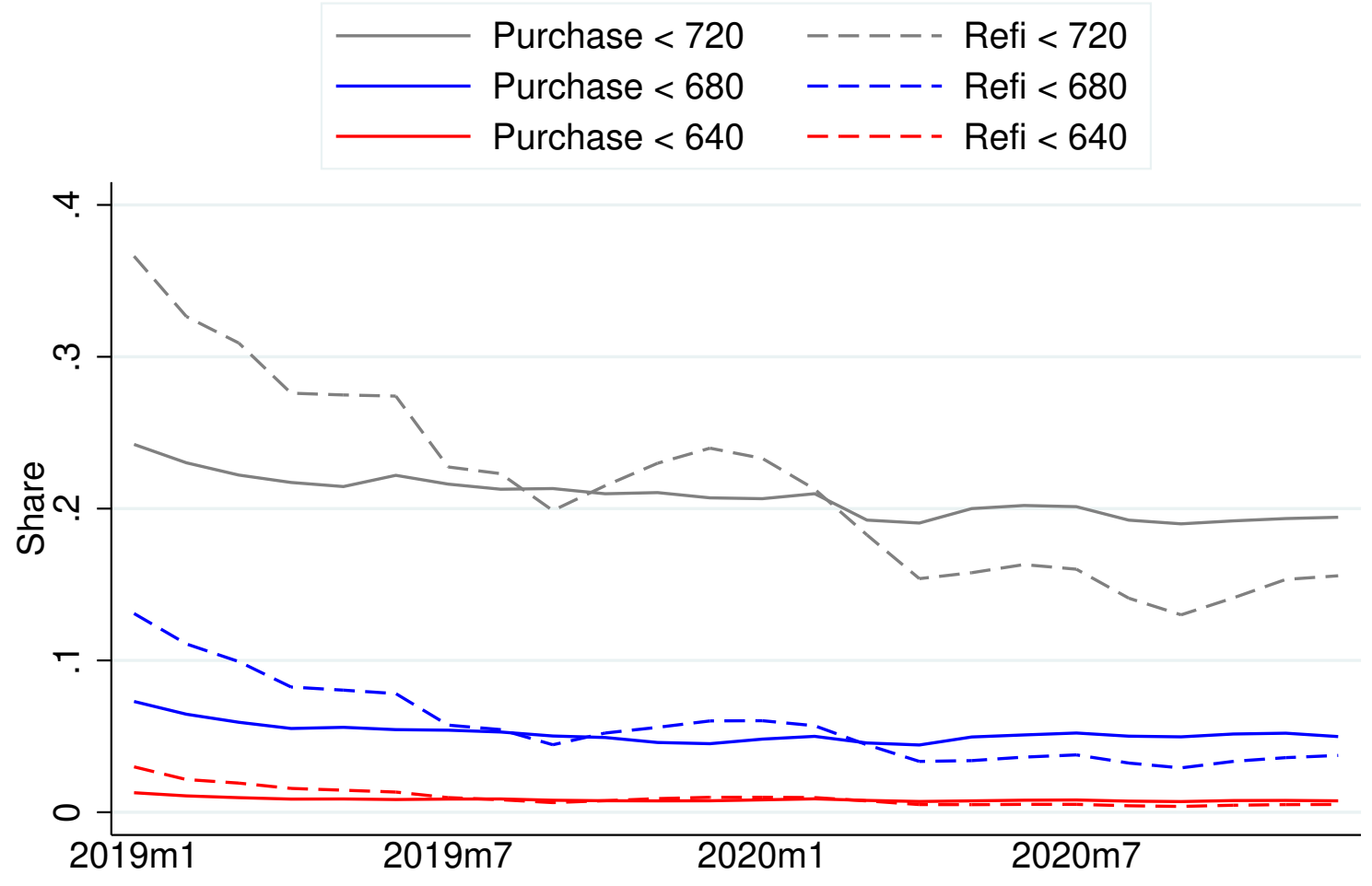

Data source: McDash Data. Note: Includes originations of 30-year, fixed-rate conventional mortgages made to owner-occupants, weighted by loan balance at origination. 


\section{Figure A.16: Credit Score Distribution: FHA}

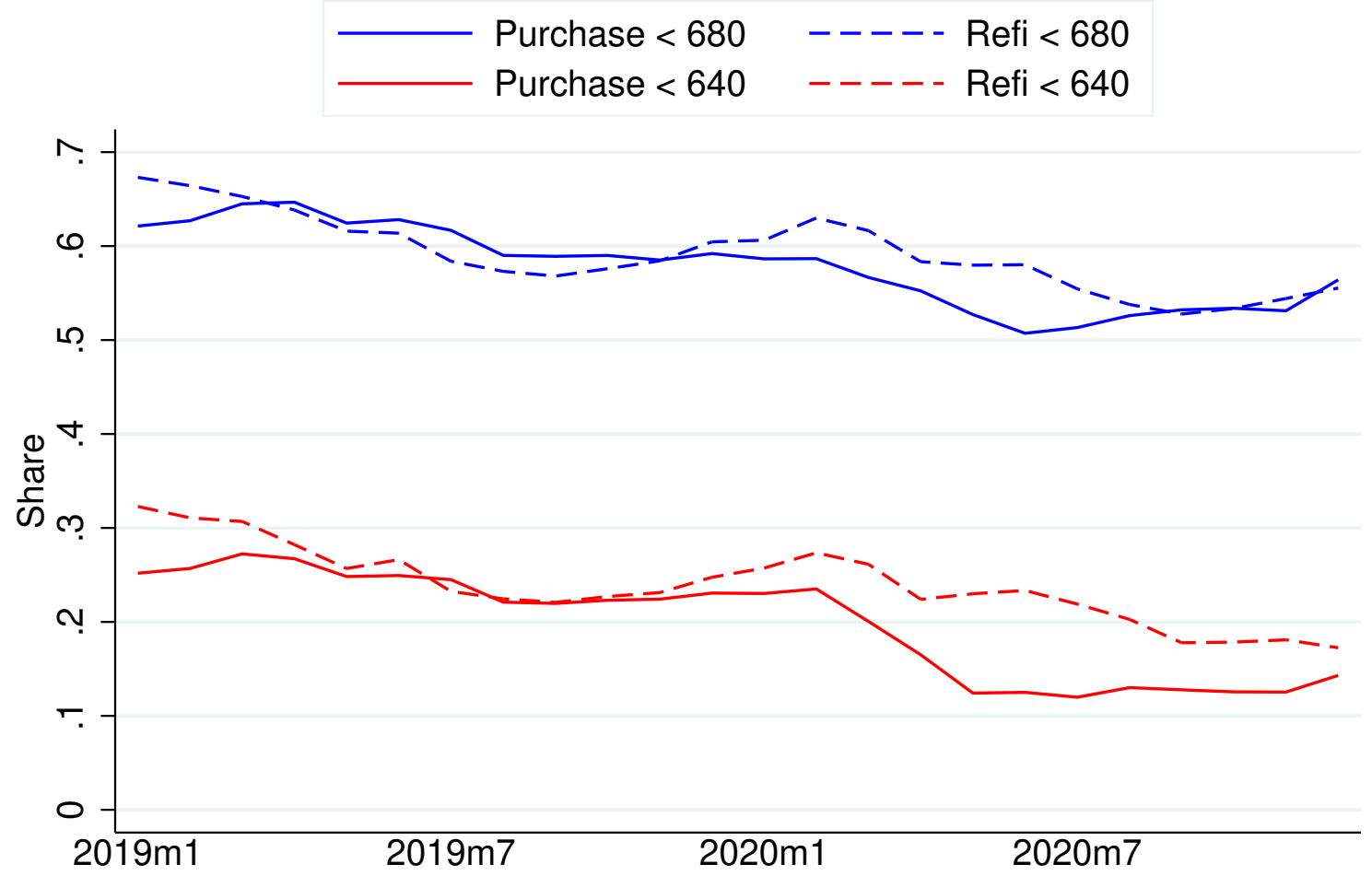

Data source: McDash Data. Note: Includes originations of 30-year, fixed-rate FHA mortgages made to owner-occupants, weighted by loan balance at origination. 


\section{Figure A.17: Credit Score Distribution: Jumbo}

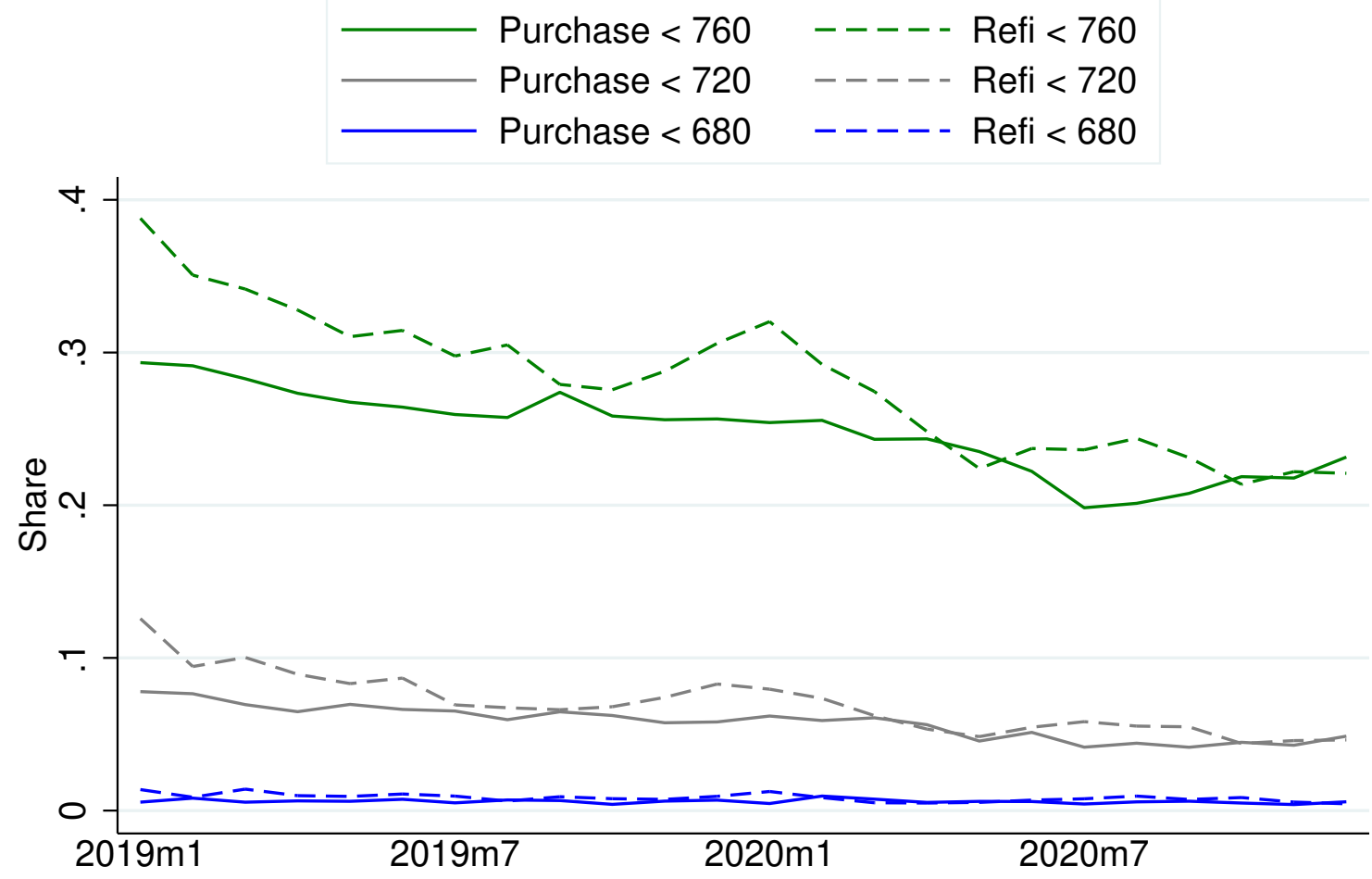

Data source: McDash Data. Note: Includes originations of 30-year, fixed-rate conventional mortgages made to owner-occupants, weighted by loan balance at origination. 


\section{G Additional Evidence on Jumbo Segment}

Figure A.18: Jumbo-conforming Spreads from Other Data Sources

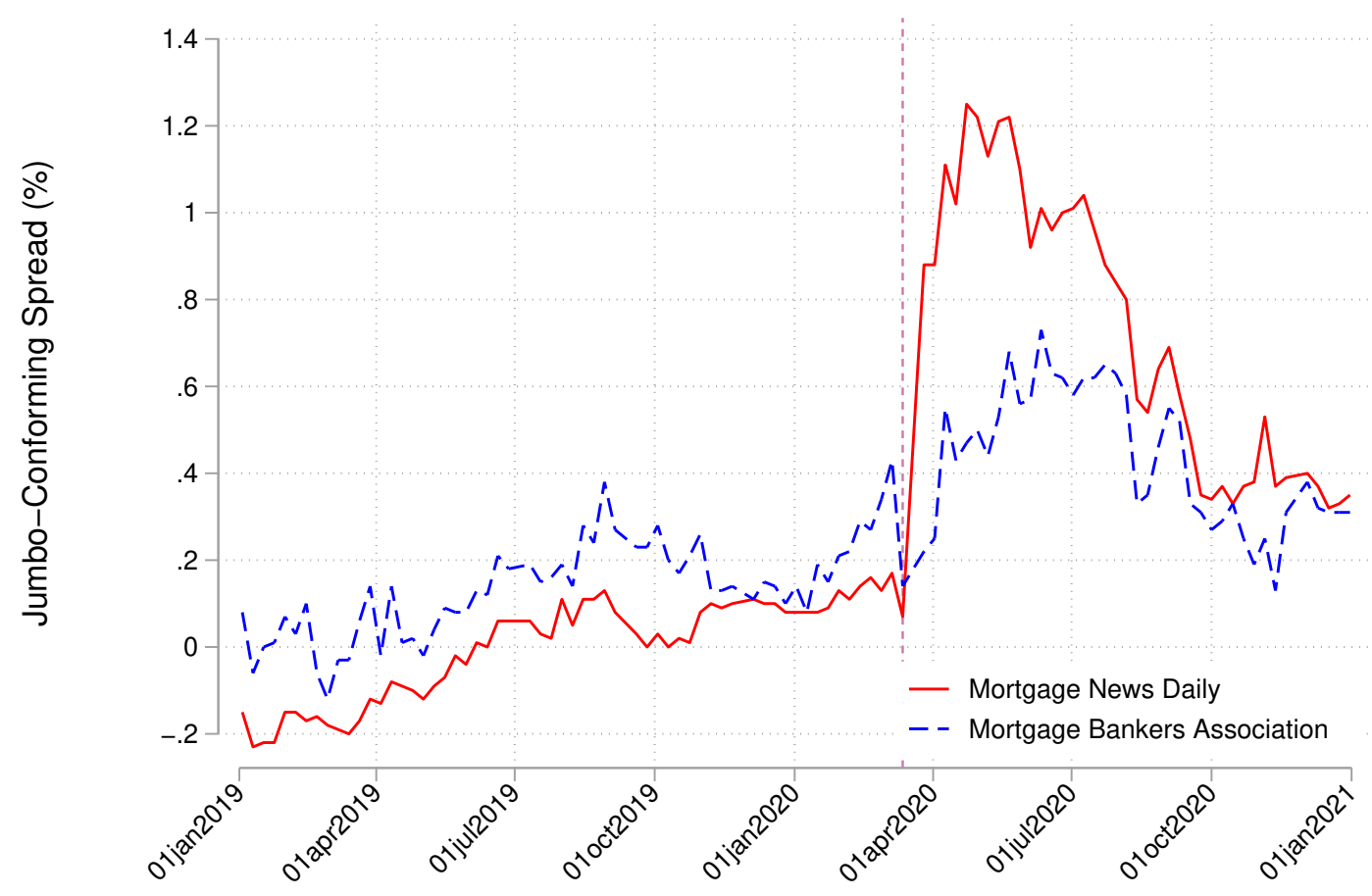

Notes: Vertical line represents the declaration of a national state of emergency on March 13, 2020. Data source: Mortgage News Daily, Mortgage Bankers Association (via Haver Analytics)

\section{G.1 Time-series Evolution of Jumbo Share in McDash Data}

Figure A.19 displays estimated coefficients on the vector of monthly time dummies from a loan-level linear probability regression of whether a mortgage is a jumbo loan, along with 95 percent confidence intervals (based on standard errors clustered by Zip code). Sample includes loans within 10 percent of either side of the conforming limit applicable to each loan (either the national or county-level limit). Jumbo loans are defined as mortgages exceeding the conforming loan limit. The data source is Black Knight McDash data ("McDash data"). 
Figure A.19: Time-series of Jumbo Share among Loans within $10 \%$ of Conforming Limit

A. Purchase mortgages

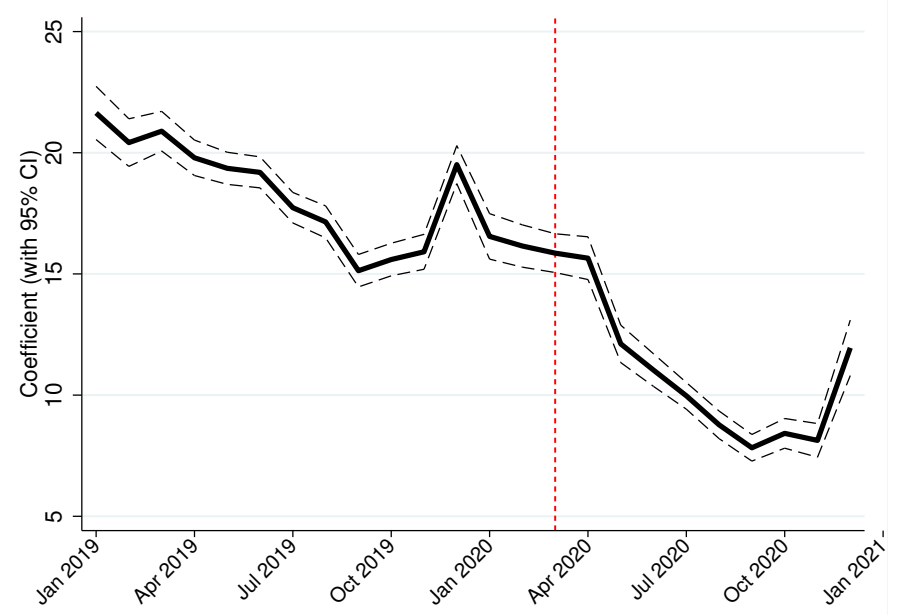

B. Refinancings

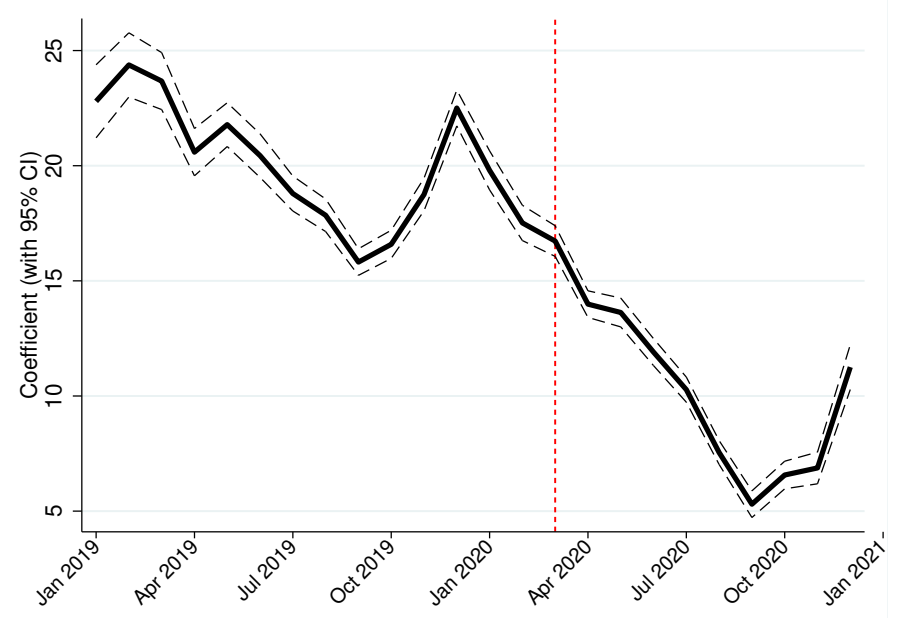

C. All mortgages

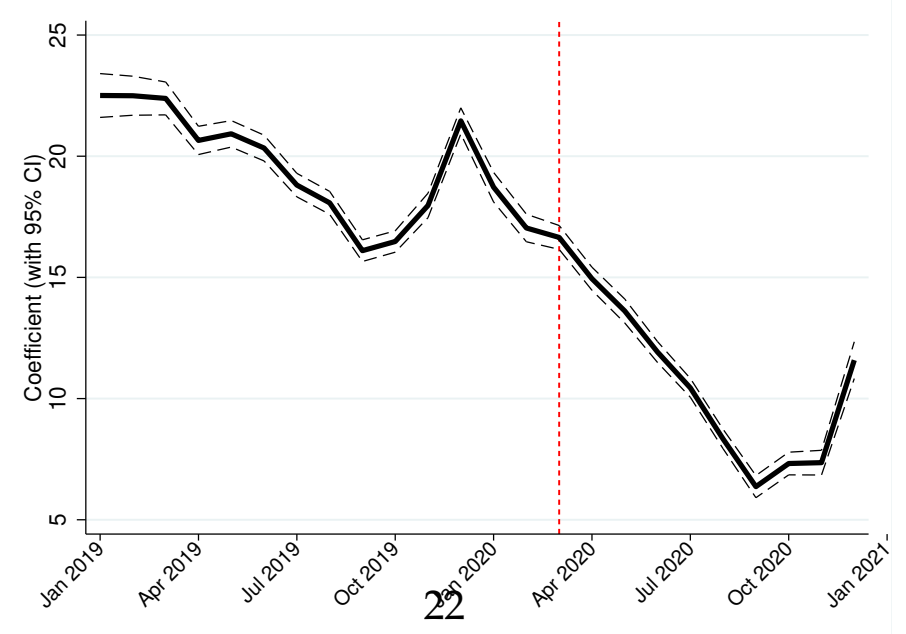

Data source: McDash 
Figure A.20: Lending above National vs. Local Conforming limit
(a) National conforming limit
(b) Local limit

Purchase mortgages:
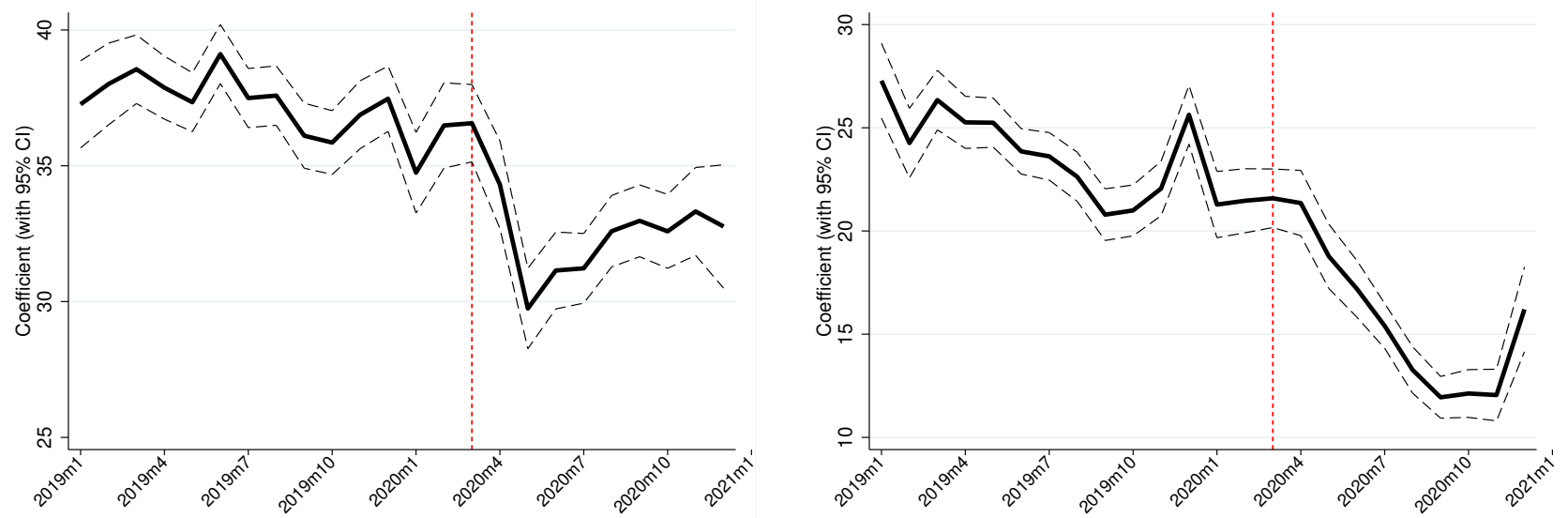

Refinances:
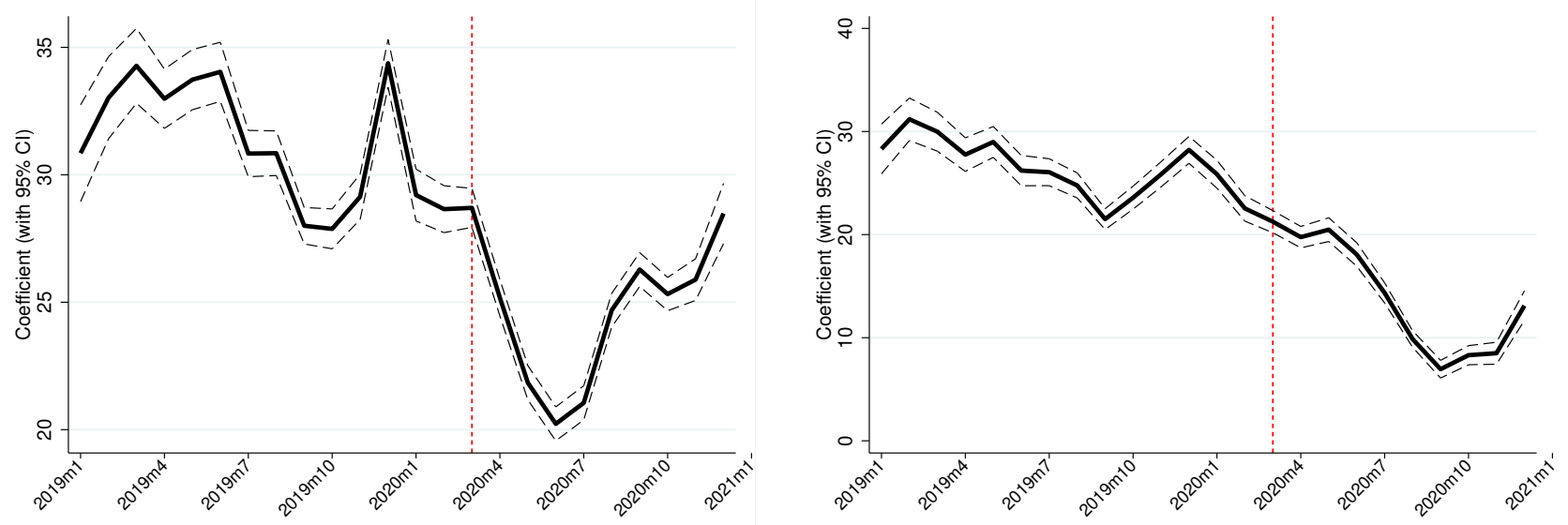

All loans:
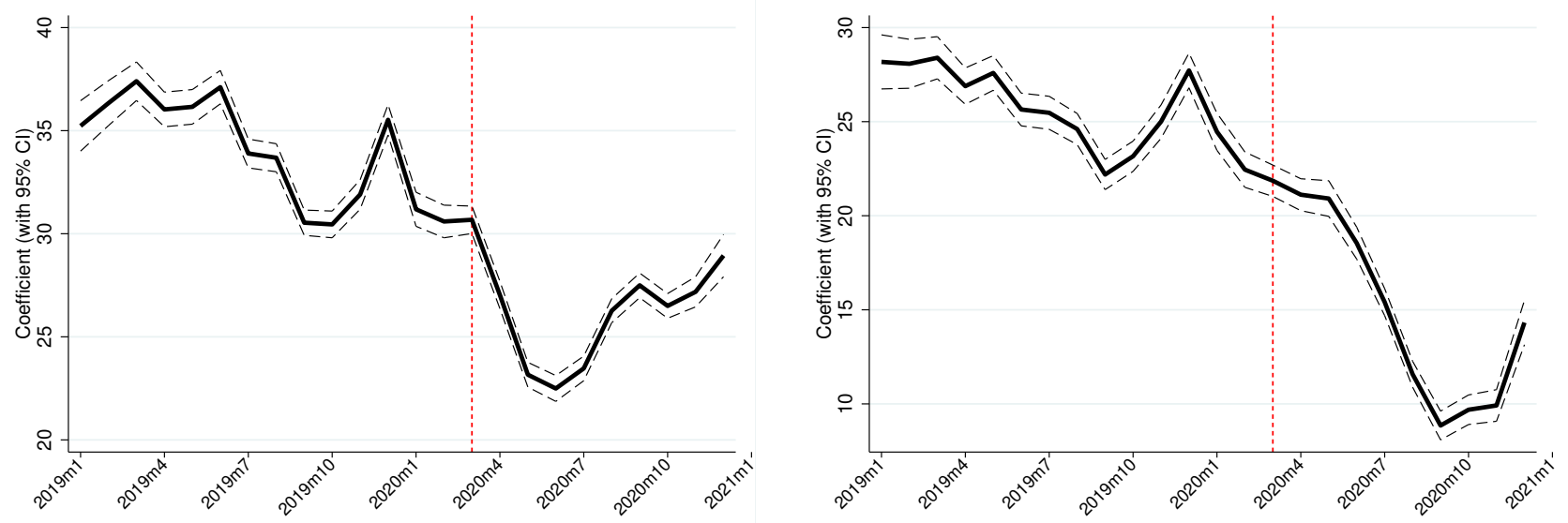

Data source: McDash. 


\section{H The Non-QM Market}

In this section, we study changes in the supply of credit for non-qualified ("non-QM") jumbo mortgages with debt-to-income (DTI) ratios exceeding 43 percent, which expose lenders to additional legal risk. Non-QM loans legally require the lender to properly verify and document that the borrower is capable of repaying the mortgage, the so-called "ability-to-repay" requirement. The non-QM market includes all jumbo mortgages with a back-end DTI ratio exceeding 43 percent, as well as certain other contract types (for example, mortgages not requiring tax returns for income documentation). DeFusco et al. (2019) find that the ability-to-repay requirement reduces lending and increases mortgage interest rates above the DTI $=43$ percent threshold.

We use Optimal Blue to analyze price and quantity for jumbos above and below a DTI of 43 , using a methodology similar to what is shown in the main text. Specifically, in the Optimal Blue Insight data we compare rate offers on otherwise identical mortgages with a DTI of 44 versus 43 . In the locks data we restrict the sample to loans with DTI $>40$, and then include a vector of DTI $>43 \times$ time fixed effects to trace out the conditional rate premium associated with a non-QM mortgage. We also calculate the share of all jumbo rate locks made to borrowers with a DTI $>43$.

The results presented in Figure A.21 show that the number of lenders serving the nonQM market drops by about 90 percent in March 2020, and offered interest rates spike by more than 100 basis points. The non-QM interest rate spread on jumbo rate locks remains fairly stable over the course of the pandemic, however, as does the non-QM share of all jumbo mortgage locks. Note that non-QMs represent only 3 percent of jumbos even before the pandemic.

One interpretation of this evidence is that specialist lenders remain active in the nonQM market and continue to lend, but non-specialists either exit or raise their offered interest rates. Non-QM lending drops in line with jumbo lending as a whole, but we find only mixed evidence of an amplified legal risk premium for non-QM loans. 


\section{Figure A.21: Credit Availability for Non-QM Mortgages}

\section{QM vs Non-QM Jumbo, LTV=80, FICO=750}
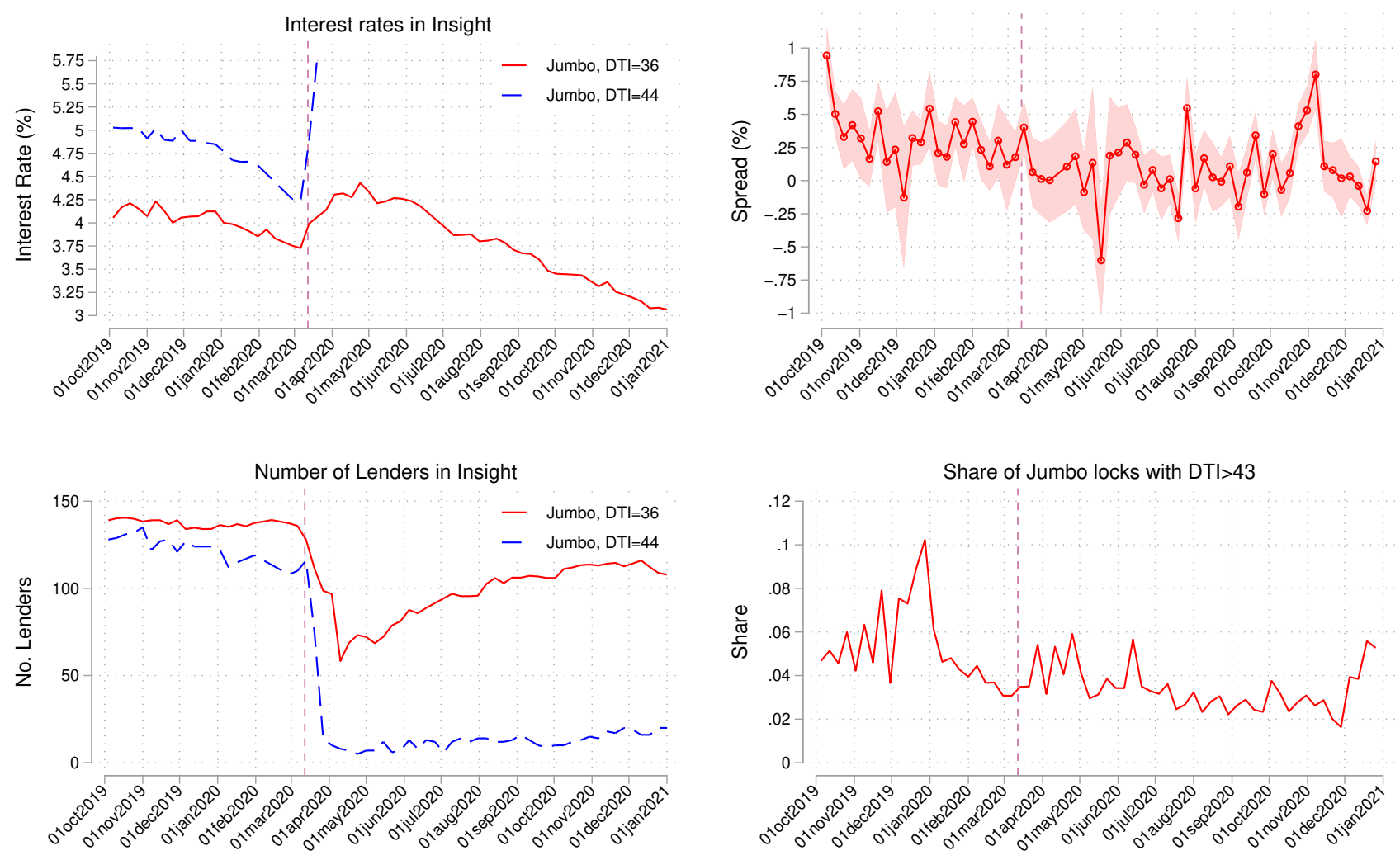

Notes: Vertical line represents the declaration of a national state of emergency on March 13, 2020. Data source: Optimal Blue 